Universidad de Lima

Escuela de Posgrado

Maestría en Tributación y Política Fiscal

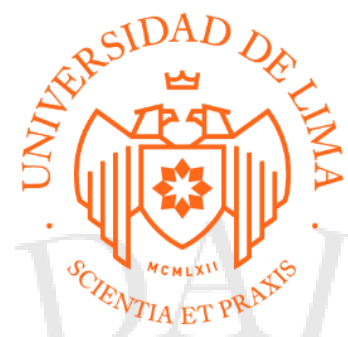

\title{
TRATAMIENTO TRIBUTARIO DE LAS CONCESIONES BIFURCADAS O MIXTAS
}

Trabajo de investigación para optar el Grado Académico de Maestro en

Tributación y Política Fiscal

\section{Vilma Edith Gonzales Villena}

Código 20162719

\author{
Asesor \\ Ramón Bueno Tizón Vivar
}

Lima - Perú

Mayo de 2019 


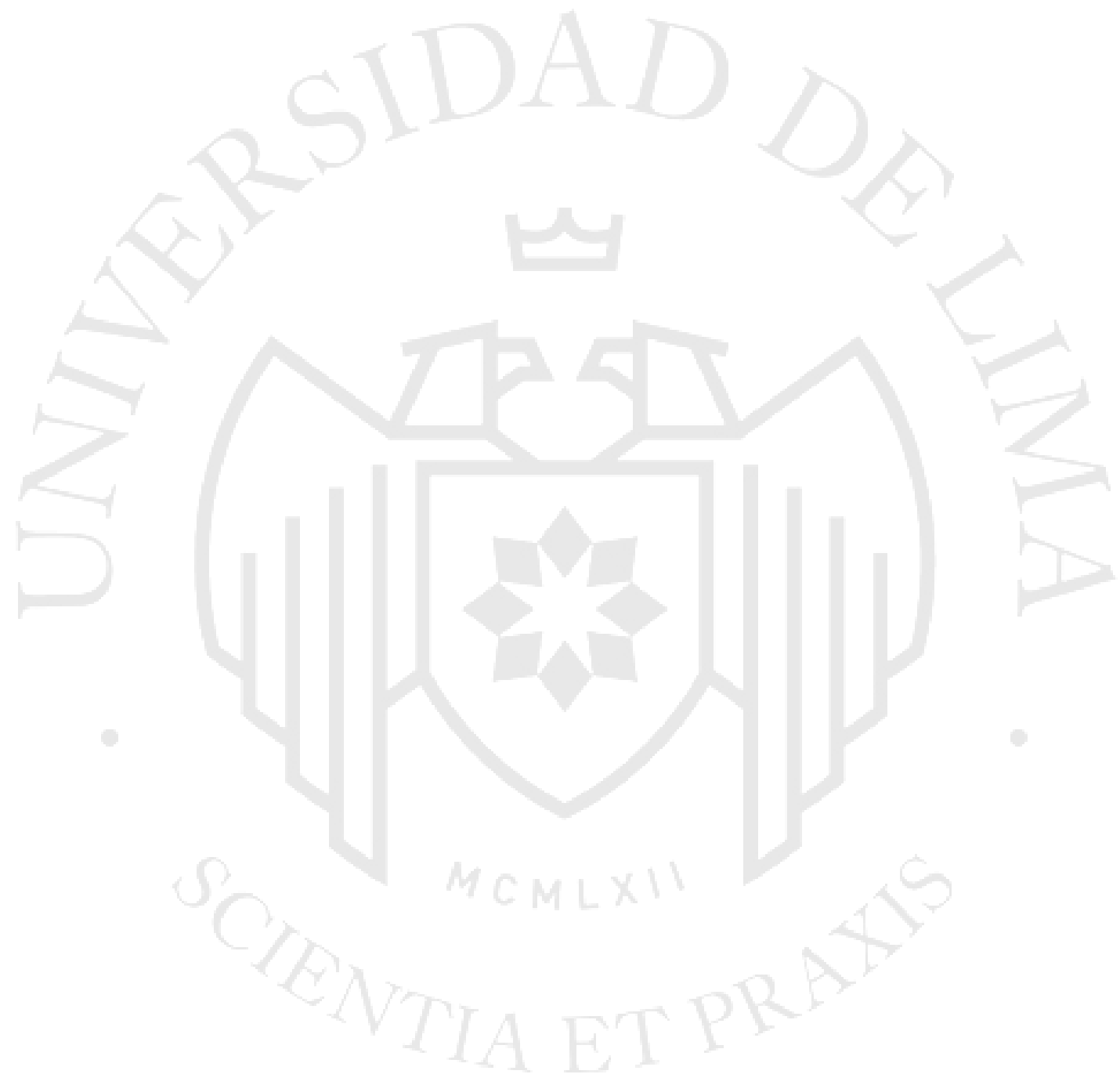




\section{TRATAMIENTO TRIBUTARIO DE LAS CONCESIONES BIFURCADAS O MIXTAS}

\section{TAX TREATMENT OF BIFURCATED OR MIXED CONCESSIONS}




\section{TABLA DE CONTENIDO}

\section{CAPÍTULO I: REGULACIÓN DE LAS CONCESIONES EN EL}

ORDENAMIENTO JURÍDICO ...........................................................................3

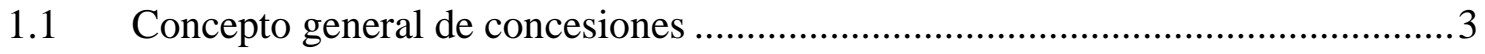

1.2 Teorías respecto a la naturaleza jurídica de las concesiones ..............................6

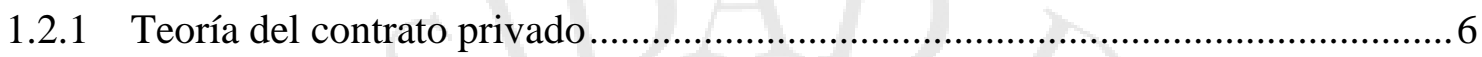

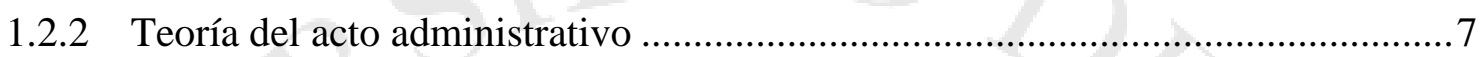

1.2.3 Teoría del acto mixto ............................................................................. 7

1.3 Concepto de concesión según Decreto Supremo N 59-96-PCM y Decreto

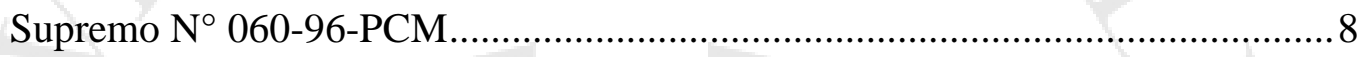

1.4 Las concesiones bajo la aplicación del Decreto Legislativo $\mathrm{N}^{\circ} 1224 \ldots \ldots \ldots \ldots \ldots . . .10$

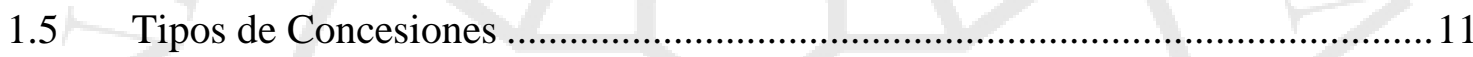

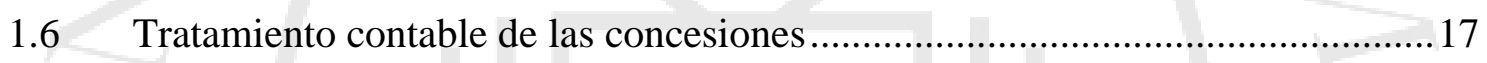

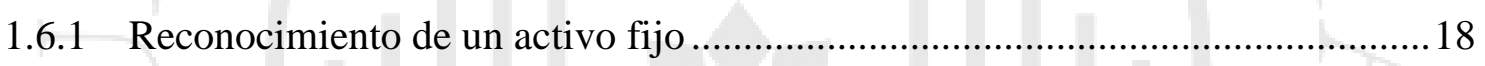

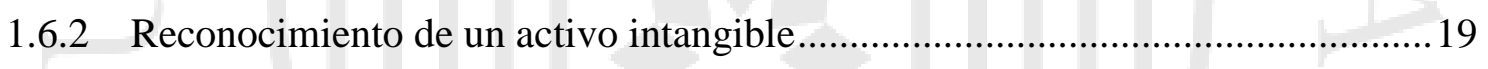

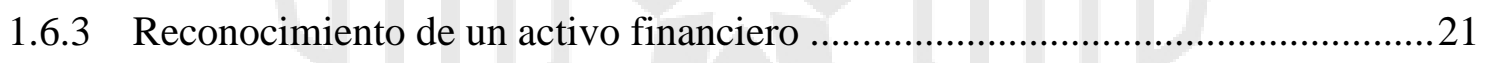

1.7 Tratamiento tributario de las concesiones en el ordenamiento jurídico peruano 24

CAPÍTULO II: CONCESIONES BIFURCADAS O MIXTAS ................................33

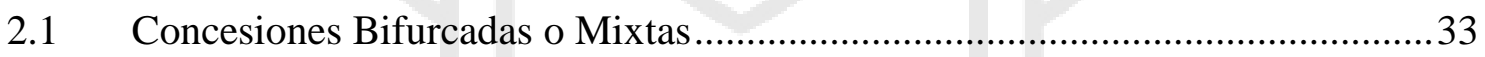

2.2 Garantías otorgadas por el Estado en las concesiones ...................................... 37

2.2.1 Ingreso Mínimo Anual Garantizado (IMAG) y Demanda Mínima Anual

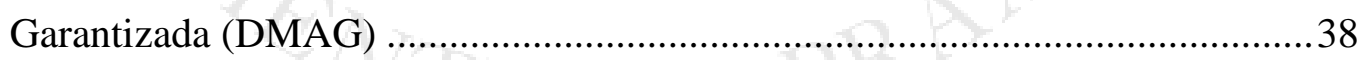

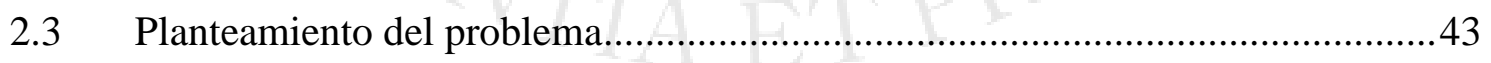

2.3.1 Limitaciones en la aplicación del artículo $22^{\circ}$ del Decreto Supremo Nº59-96PCM

2.3.2 Aplicación parcial del artículo $22^{\circ}$ del Decreto Supremo N $^{\circ}$ 059-96-PCM en las concesiones bifurcadas o mixtas

2.3.3 Aplicación del régimen general del Impuesto a la Renta en las concesiones bifurcadas o mixtas 
2.4 Remisión a las normas contables y la inseguridad jurídica para los concesionarios

2.4.1 Regulación contable de las concesiones bifurcadas o mixtas según la Interpretación CINIIF 12 Acuerdos de Concesión de Servicios .58

2.4.2 Implicancias tributarias por el reconocimiento de un activo financiero y un activo intangible en aplicación de la Interpretación CINIIF 12.

CAPÍTULO III: NUESTRA PROPUESTA NORMATIVA .066

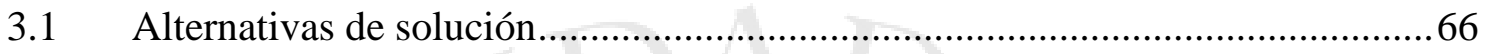

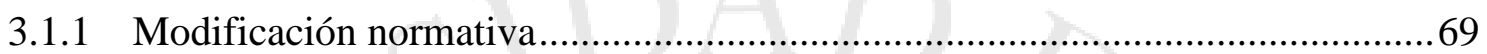

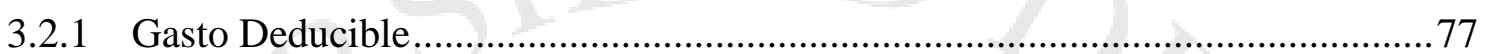

CONCLUSIONES Y RECOMENDACIONES.......................................................81

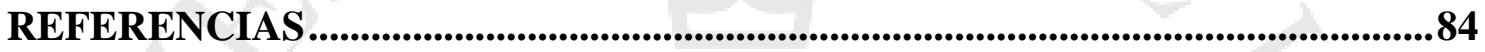

BIBLIOGRAFÍA .................................................................................................8 88 


\section{RESUMEN}

En este estudio se investiga el impacto tributario y económico de las Concesiones Bifurcadas o Mixtas, en las que el riesgo de explotación y/o demanda es asumido contractualmente por el concedente y el concesionario. En la investigación se determina que, estas concesiones no gozan de un tratamiento específico dentro del artículo $22^{\circ}$ del Decreto Supremo $\mathrm{N}^{\circ}$ 059-96-PCM (Ley de Concesiones), dado que esta norma ha delimitado su ámbito de aplicación a los bienes materia de concesión que califiquen únicamente como activos fijos y activos intangibles, dejando fuera de su alcance a los bienes clasificados como activos financieros acorde a lo establecido en la Interpretación CINIIF 12 - Acuerdos de Concesión de Servicios, y que surgen en este tipo de concesiones. Por ende, resulta imprescindible la modificación del artículo $22^{\circ}$ de la Ley de Concesiones.

Palabras clave: Concesión Bifurcada, CINIIF 12, Ley de Concesiones, IMAG 


\begin{abstract}
This study investigates the tax and economic impact of Bifurcated or Mixed Concessions, in which the risk of exploitation and/or demand is assumed contractually by the government and the concessionaire. In the investigation it is determined that, these concessions do not enjoy a specific treatment within article 22 of Supreme Decree No. 059-96-PCM (Concessions Law), since this rule has delimited its scope of application to property subject to concession that qualifies only as fixed assets and intangible assets, leaving out of scope the property classified as financial assets in accordance with the IFRIC 12 - Service Concession Arrangements, and arising in this type of concessions. Therefore, the modification of article 22 of the Concessions Law is essential.
\end{abstract}

Keywords: Bifurcated Concession, IFRIC 12, Concessions Law, IMAG 


\section{ÍNDICE DE TABLAS}

Tabla 3.1 Cálculo del valor del activo financiero............................64

Tabla 3.2 Cálculo del valor del activo intangible............................64

Tabla 3.3 Registro contable durante la etapa de construcción...............................64

Tabla 3.4 Registro contable durante la etapa de explotación.....................65

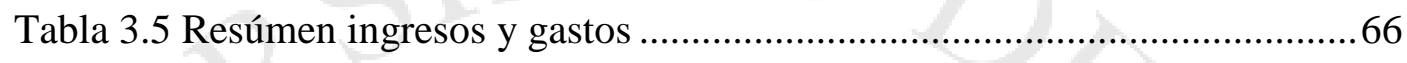




\section{INTRODUCCIÓN}

Las concesiones constituyen una herramienta valiosa e importante utilizada para el desarrollo económico de los países en vías de crecimiento y modernización. El Estado Peruano no es ajeno al uso de este tipo de herramientas. Ello, debido a que aún no cuenta con la capacidad tecnológica y/o económica suficiente para ejecutar con sus propios medios la construcción y/o mantenimiento de obras públicas de infraestructura, así como la prestación de servicios públicos en beneficio de los ciudadanos. Por lo tanto, para cumplir con este propósito el Gobierno Peruano ha ido buscando constantemente las formas más adecuadas de conseguir financiamiento, siendo que a lo largo de los años y con mayor fuerza desde la época de los noventa, las concesiones han representado el camino más apropiado e idóneo, atrayendo la inversión privada tanto nacional como extranjera, y de esa forma contribuyendo al crecimiento económico.

Sin embargo, para un país como el nuestro que celebra una importante cantidad de contratos de concesión y con el fin de atraer mayor inversión privada, resulta imprescindible contar con una normativa legal sólida, que regule todos los aspectos que involucra la suscripción de dichos contratos. Ello, toda vez que a través de estos contratos el Estado le confiere ciertos derechos y obligaciones a los concesionarios privados, que deben ser respaldados con una legislación idónea, especialmente en el ámbito tributario. Se debe tener en cuenta que en la actualidad está regulado el tratamiento fiscal de las concesiones de tipo autosostenibles, exceptuando otras figuras de concesión no menos importantes, dentro de las cuales están las concesiones de tipo bifurcadas o mixtas. Por lo tanto, al no contar con una legislación tributaria con bases sólidas se generan contingencias e inseguridad jurídica para el inversionista.

En el presente trabajo de investigación titulado "Tratamiento tributario de las concesiones bifurcadas o mixtas" se abordarán las principales contingencias que se presentan en el ámbito fiscal para el inversionista privado. Al carecer de una regulación sólida en la normatividad tributaria, resulta necesario e indispensable remitirse a las normas de carácter contable que establecen su tratamiento de forma legible como es la Interpretación CINIIF 12 Acuerdos de Concesión de Servicios. Ello origina que en este 
tipo de concesiones donde el riesgo de demanda es asumido de una parte por el Estado a través de la figura del IMAG (Ingreso Mínimo Anual Garantizado) y, por otra parte, asumido por los usuarios, se reconozca tanto un activo financiero como un activo intangible. Esta clasificación contable no está regulada expresamente por el Texto Único Ordenado de Concesiones, aprobado mediante el Decreto Supremo Nº59-96-EF, ni por la propia Ley del Impuesto a la Renta ni su Reglamento. Por lo tanto, no resulta aplicable el régimen especial fiscal contenido en dicha norma para los activos financieros, mientras que, para el tratamiento del activo intangible, si resulta aplicable el régimen fiscal abordado en el citado decreto supremo, sin embargo, con ciertas limitaciones.

Por su parte, resaltar que el tratamiento tributario de este tipo de concesiones constituye una situación sui-generis y en razón a ello son escasos los pronunciamientos emitidos por la Administración Tributaria, así como del Tribunal Fiscal. Pese a ello, los concesionarios vienen aplicando un tratamiento fiscal bajo la diligencia de las normas contables. Sin embargo, este criterio no genera ningún tipo de seguridad jurídica, y está supeditado a diversas interpretaciones, sin un respaldo normativo fiscal sólido. Es en razón a estas consideraciones que en el presente trabajo se analizarán las contingencias y controversias generadas en la celebración de dichos contratos de concesión y se propondrán las posibles soluciones en su tratamiento.

En ese sentido, el presente trabajo de investigación se desarrollará bajo el siguiente esquema: En el primer capítulo se abordará el concepto de las concesiones en general, las teorías respecto a su naturaleza jurídica, así como su clasificación, se analizará el tratamiento contable y tributario de las concesiones en general, bajo la aplicación de las normas contables y el Decreto Supremo No 059-96-PCM. Posteriormente, el capítulo segundo ahondará el tratamiento contable y tributario de las concesiones de tipo bifurcadas o mixtas, en el cual se analizará la principal contingencia tributaria generada para los inversionistas. En el último capítulo se propondrán las posibles soluciones y las recomendaciones necesarias para forjar mayor seguridad jurídica. 


\section{CAPÍTULO I: REGULACIÓN DE LAS CONCESIONES EN EL ORDENAMIENTO JURÍDICO}

Desde la década de los noventa, los contratos de concesión han sido hasta la actualidad una herramienta y/o un instrumento imprescindible para el Estado Peruano, mediante el cual no solo se busca el financiamiento del sector privado en favor del país sino también el desarrollo económico y social de la nación. A través de ellos el concedente (Estado) otorga ciertos derechos y obligaciones a un concesionario (tercero privado) para que este ejecute la construcción o dirección de una obra de infraestructura y/o la prestación de servicios públicos en beneficio de los usuarios por un periodo de tiempo determinado. Por ello, es importante que se desarrolle de manera amplia el concepto de concesiones y sus alcances generales dentro del ordenamiento jurídico peruano, así como su tratamiento contable y tributario en general.

\subsection{Concepto general de concesiones}

Las concesiones son un mecanismo utilizado por el Estado (concedente) mediante el cual, el mismo le confiere $\mathrm{u}$ otorga ciertos derechos y obligaciones a un tercero privado nacional o internacional (concesionario), con la finalidad de que este se encargue de la construcción y/o explotación de una obra pública de infraestructura y/o la prestación de un servicio público en beneficio de los usuarios de los mismos, por un periodo de tiempo determinado en el contrato y con la condición de que al término de dicho periodo, se le devuelva al Estado el bien o servicio concesionado. Este instrumento es utilizado frecuentemente por países como el Perú, que no cuentan con la suficiente capacidad económica y tecnológica para llevar a cabo estos proyectos públicos, por lo que, resulta necesario e indispensable atraer la inversión privada y buscar fuentes de financiamiento para ejecutar estos propósitos y fomentar el desarrollo.

En mérito a ello, la regulación del tratamiento de las concesiones dentro del ordenamiento jurídico peruano está establecida primordialmente en la Constitución Política del Perú, el cual sostiene en sus artículos $66^{\circ}$ y $73^{\circ}$ lo siguiente: 
Artículo 66 $^{\circ}$. - Los recursos naturales, renovables y no renovables, son patrimonio de la Nación. El Estado es soberano en su aprovechamiento.

Por ley orgánica se fijan las condiciones de su utilización y de su otorgamiento a particulares. La concesión otorga a su titular un derecho real, sujeto a dicha norma legal.

$\underline{\text { Artículo 73 }^{\circ}}$. - Los bienes de dominio público son inalienables e imprescriptibles. Los bienes de uso público pueden ser concedidos a particulares conforme a ley, para su aprovechamiento económico. (Constitución Política del Perú, 1993).

Al respecto, la principal norma del ordenamiento jurídico peruano, la Carta Magna, le otorga facultades al Estado para convocar a terceros privados mediante procesos de selección, con la finalidad de elegir al mejor demandante y otorgarle la responsabilidad de explotación de los bienes de uso público. La norma antes citada precisa que se otorga un "derecho real" a su titular. Este derecho que por naturaleza le corresponde al Estado le será otorgado a través de la concesión al concesionario. Sin embargo, no se trata de conceder el derecho de propiedad, sino la facultad de usufructo del bien concedido.

El literal b) del artículo $1^{\circ}$ del Reglamento de Los Beneficios Tributarios para La Inversión Privada en Obras Publicas de Infraestructura y de Servicios Públicos, aprobado mediante Decreto Supremo $N^{\circ}$ 132-97-EF señala que, la concesión es una "modalidad contractual a través de la cual se promueve la inversión privada en obras públicas de infraestructura y de servicios públicos, según lo dispuesto por el Artículo $2^{\circ}$ del TUO”.

Ahora bien, Gómez de la Torre Barrera (2001), ha precisado un concepto más amplio de las concesiones, el autor señala que:

En efecto, el otorgamiento de concesiones implica que el Estado entrega al concesionario únicamente la tenencia de ciertos bienes o la administración de determinados servicios públicos por el plazo de vigencia de la concesión. No es por tanto una cesión en propiedad, toda vez que el Estado al término de la misma no vuelve a adquirir los bienes que fueron cedidos puesto que nunca se desprendió totalmente de ellos. En efecto, tan solo dejó de lado su explotación efectiva, liberándose de una carga representada por la realización a su cuenta y riesgo, de las 
inversiones de capital requeridas o la adquisición de la tecnología necesaria.

En ese sentido la entrega de concesiones en nuestro sistema sólo implica de manera relativa una forma de privatización en la medida que el concesionario no recibe la propiedad de los bienes que le son concedidos. (p. 74).

Por su parte, Pedreschi Garcés (2009), sostiene que:

Con carácter preliminar, cabe señalar que, de acuerdo a lo establecido en el ordenamiento actualmente vigente, la concesión constituye uno de los mecanismos previstos para que el Estado, a través de sus diversos niveles, promueva la participación de la inversión del sector privado, con la finalidad de la ejecución de obras públicas de infraestructura y de servicios públicos. (p. 251).

Ahora bien, García Novoa (1994), señala entre otros:

La concesión es un acto administrativo que hace nacer en la esfera jurídica de su destinatario un derecho hasta el momento inexistente -la gestión de un servicio público o la utilización privativa del dominio público-... Tenemos, por tanto, un aumento patrimonial susceptible de valoración económica, constituido por el ingreso en la esfera de intereses del concesionario de un título inmediato atributivo de los derechos comprendidos por la concesión. (p. 103).

Por lo tanto, la doctrina en mayor medida establece que una concesión se define como una actuación propia del Estado. Por ello la denominan como un acto administrativo, estableciendo a través de este, derechos susceptibles de un posterior otorgamiento, dando paso consecuentemente a la explotación de una obra pública de infraestructura o prestación de un servicio público por parte de un tercero privado. Cabe señalar, que surge el aprovechamiento, explotación o usufructo de los bienes y/o servicios cedidos en concesión, por un periodo de tiempo determinado en el contrato y que además no debe exceder del límite máximo temporal indicado en las leyes generales sobre la materia. 


\subsection{Teorías respecto a la naturaleza jurídica de las concesiones}

Los contratos de concesión han sido objeto de debate para precisar su definición y naturaleza. Existen algunos autores quienes, hasta cierta época, centraban sus ideas en que una concesión de obra es meramente un tema contractual que debe ser manejado e interpretado bajo las normas del derecho privado, en el cual se presenta la libertad contractual de ambas partes (Estado y Concesionario). Sin embargo, otro grupo de autores sostiene que las concesiones son actos administrativos celebrados por el Estado, es decir que actúa, de acuerdo a su facultad de ius imperium. Adicionalmente a estas corrientes interpretativas surgió otro grupo de autores quienes sustentan que las concesiones constituyen una combinación de ambos aspectos.

\subsubsection{Teoría del contrato privado}

Gómez de la Torre Barrera (2001), atendiendo a la teoría del contrato privado, desarrolló lo siguiente:

Sus defensores sostenían que la concesión debía ser entendida como un contrato privado, en donde el derecho civil debía regir el destino del mismo.

Según los defensores de esta teoría, el Estado podía actuar también en un segundo plano, uno de igualdad, ocupando la posición que normalmente le correspondería a otro particular y, por tanto, sometiéndose a las normas del derecho común.

La teoría del contrato privado se basaba también en la idea de que las partes en una concesión (Estado y concesionario) actúan de manera voluntaria, ejerciendo sus derechos y decidiendo por propia voluntad respetar mutuamente un contrato en los términos negociados. (pp. 77-78).

Por su parte, Calafell Irabién (1996) opina entre otros que:

Por lo que se ve en esta circunstancia, se piensa en una relación, en el que el concesionario y el Estado se obligan recíprocamente por las cláusulas convencionales, creando una situación contractual sujeta a las reglas del 
Derecho Civil, tanto en su formación, como en su interpretación y los consecuentes derechos y obligaciones. (p. 217).

\subsubsection{Teoría del acto administrativo}

La teoría del acto administrativo o del acto unilateral de la Administración señala que:

La teoría del acto administrativo o del acto unilateral de la Administración surge en reacción frente a la teoría clásica recientemente analizada, y predica en líneas generales que la concesión de obra pública implica un acto de soberanía estatal, en donde el Estado se coloca en un plano de total superioridad frente a los particulares.

En este sentido, se deja de lado la participación de dos partes contratantes, toda vez que en la práctica sería el Estado -actuando como entidad concedente- quien en ejercicio de su poder de imperio decide por sí mismo el perfeccionamiento o no de la concesión. De esta manera, la única voluntad necesaria para la entrega en concesión de una obra pública sería la del Estado, quien decidiría cómo, cuándo y a quién entregar la concesión, sin otorgar posibilidad alguna al concesionario de participar en la negociación y menos aún, sin concederle mayores derechos frente a él. Bajo estos criterios, nos encontramos frente a un acto puro de liberalidad del Estado concedente. (Gómez de la Torre Barrera, 2001, p.78)

Asimismo, Calafell Irabién (1996) establece que, “contrapuesta a la doctrina contractual, se encuentra la que estima a la concesión como un acto unilateral, o sea un acto típico de poder público, en ejercicio exclusivo de la potestad soberana" (p. 217).

\subsubsection{Teoría del acto mixto}

Aquellos que sostienen esta teoría, entienden a la concesión como una combinación de las dos teorías antes desarrolladas. Es decir que el Estado, en base a su ius imperium, establece todos los requisitos y términos más convenientes para transmitir su poder de gestión a un tercero, pero sujetándose a un contrato privado en el cuál rigen las normas 
del derecho civil. Esta teoría desarrollada por Gómez de la Torre Barrera (2001) manifiesta que:

La teoría conocida como la del acto complejo, mixta o simplemente ecléctica, plantea la coexistencia de un aspecto legal o reglamentario y de un aspecto contractual, en las concesiones de obra pública.

Así, en el aspecto legal o reglamentario se incluyen todas aquellas normas que regulan el otorgamiento de las concesiones y que implican un acto unilateral del Estado. De esta manera, la entidad concedente puede fijar condiciones y requisitos en ejercicio de su poder de imperio, teniendo como límite el resguardo del interés público.

Frente a ello, en aplicación de su aspecto contractual, se crean derechos y obligaciones en favor y a cargo de cada una de las partes contratantes, los mismos que quedan establecidos al momento de la suscripción del contrato de concesión correspondiente, momento a partir del cual se originan situaciones que no podrán ser modificadas sin el consentimiento de la contraparte. (p. 79).

"Esta tercera solución... la concesión considerada como un acto mixto, se descompone en dos elementos: la situación reglamentaria y el contrato administrativo, de aquí se desprenden sus dos fases: como acto unilateral y como acto contractual" (Calafell Irabién, 1996, p. 218).

\subsection{Concepto de concesión según Decreto Supremo N $^{\circ}$ 59-96-PCM y Decreto Supremo $\mathbf{N}^{\circ}$ 060-96-PCM}

El Decreto Supremo N 059-96-PCM, Texto Único Ordenado de las normas con rango de ley que regulan la entrega en concesión al sector privado de las obras públicas de infraestructura y de servicios públicos, en adelante la Ley de Concesiones, ha desarrollado una definición del término "Concesión". En efecto, el artículo $2^{\circ}$ del citado Decreto establecía que, la concesión es una modalidad mediante la cual se promueve la inversión privada, en el ámbito de las obras públicas de infraestructura y de servicios públicos. Añade que las concesiones, licencias, autorizaciones, permisos, servidumbres y otros que se requieran para la utilización de recursos naturales, la ejecución de obras de 
infraestructura y la prestación de servicios públicos se rigen por lo establecido en las leyes sectoriales correspondientes.

Por su parte, el artículo $3^{\circ}$ del mismo cuerpo legal, establece que:

El presente Decreto Legislativo promueve la inversión privada en obras de infraestructura y/o de servicios públicos, y regulan su explotación, para cuyo efecto se podrá otorgar concesiones a personas jurídicas, nacionales o extranjeras, para la construcción, reparación, conservación y explotación de obras públicas de infraestructura y de servicios públicos. La concesión de la obra implica la explotación del servicio.

Es importante notar que, el artículo $13^{\circ}$ precisa lo siguiente:

La concesión sobre bienes públicos no otorga un derecho real sobre los mismos, en estos casos, el contrato de concesión constituirá título suficiente para que el concesionario haga valer los derechos que dicho contrato le otorga frente a terceros, en especial el de cobrar las tarifas, precios, peajes u otros sistemas de recuperación de las inversiones, pues será en estos supuestos, que el concesionario podrá explotar el o los bienes objeto de la concesión por cuenta propia o por medio de terceros, quedando siempre como único responsable frente al Estado.

Ahora bien, el Decreto Supremo Nº60-96-PCM, Reglamento del Texto Único Ordenado de las normas con rango de ley que regulan la entrega en concesión al sector privado de las obras públicas de infraestructura y de servicios públicos, en adelante Reglamento de la Ley de Concesiones, establece que debe entenderse por concesión al acto administrativo por el cual el Estado otorga a las personas jurídicas nacionales o extranjeras la ejecución y explotación de determinadas obras públicas de infraestructura o la prestación de determinados servicios públicos, aprobados previamente por la PROMCEPRI, por un plazo establecido.

De lo expuesto, estas normas regulaban la definición de las concesiones, así como su ámbito de aplicación y alcance. Nótese que, estos decretos reglamentaban la facultad del Estado de otorgar a los terceros privados un derecho de gestión, mas no un derecho real sobre las concesiones involucradas. Es decir, no se está transfiriendo el derecho de la propiedad a los concesionarios, sino meramente se les otorga una facultad de usufructo 
sobre el bien materia de concesión, con la finalidad de recuperar la inversión inicial que ha asumido el concesionario. Por ende, el Estado bajo ninguna circunstancia pierde la propiedad total (derecho real) sobre las obras de infraestructura otorgadas en concesión.

\subsection{Las concesiones bajo la aplicación del Decreto Legislativo $\mathrm{N}^{\circ} 1224$}

El Decreto Legislativo $\mathrm{N}^{\circ} 1224$ del Marco de Promoción de la Inversión Privada mediante Asociaciones Público Privadas y Proyectos en Activos, que entró en vigencia a partir del 25/09/2015, ha derogado mediante su Única Disposición Complementaria Derogatoria, el Texto Único Ordenado de las normas con rango de Ley que regulan la entrega en concesión al sector privado de las obras públicas de infraestructura y de servicios públicos, aprobado mediante Decreto Supremo N 059-96-PCM, excepto el primer y segundo párrafo del artículo $19^{\circ}$ y el artículo $22^{\circ}$.

Este dispositivo legal establece los procesos y modalidades de promoción de la inversión privada en el país, es decir la dinamización de los capitales, para el desarrollo de la infraestructura y servicios públicos, proyectos de investigación aplicada y/o innovación tecnológica, mediante la modalidad de Asociación Público Privada (APP) y la ejecución de Proyectos en Activos.

Las APP son modalidades de participación del sector privado en las que este incorpora experiencia, conocimiento, especialización y tecnología con el objetivo de lograr mejores diseños, financiar, construir, mantener y operar la infraestructura y prestar servicios públicos con exigentes y obligatorios estándares de desempeño. (Escobal Mc Evoy, 2017, p. 10)

Ahora bien, entre sus aportes más interesantes para el ámbito de las concesiones, señala textualmente en el numeral 12.1 del artículo $12^{\circ}$ lo siguiente:

El contrato desarrollado bajo la modalidad de Asociación Público Privada constituye título suficiente para que el inversionista haga valer los derechos que dicho contrato le otorga frente a terceros, en especial el de cobrar las tarifas, precios, peajes u otros sistemas de recuperación de las inversiones, así como los beneficios adicionales expresamente convenidos en el contrato, pudiendo incluir servicios complementarios. El inversionista puede explotar el o los bienes objeto de la Asociación 
Público Privada por cuenta propia o por medio de terceros, quedando siempre como único responsable frente al Estado. Sin perjuicio de lo anterior, la modalidad de entrega en concesión al inversionista que recaiga sobre bienes públicos no otorga un derecho real sobre los mismos.

Queda claro que, mediante este artículo, se ha incluido a la Concesión como una figura de asociación público privada, otorgándole al concesionario el derecho de usufructo de los bienes dados en concesión para la recuperación de su inversión. Asimismo, este artículo le da la facultad al concesionario de explotar la infraestructura por medio de terceros con los que el Gobierno Público no ha celebrado directamente el contrato de concesión, precisando que finalmente será el concesionario el responsable de dar cuentas al Estado. Concluye textualizando que, mediante las concesiones el Estado no está cediendo su derecho real sobre los bienes, no se desvincula de su derecho a la propiedad sobre estos.

\subsection{Tipos de Concesiones}

Las concesiones se clasifican desde varios enfoques o puntos de vista. Entre ellos se consideran por ejemplo la modalidad de financiamiento, su estructura y/o esquema, o incluso se clasifican por la forma de retribución al concesionario.

La Ley de Concesiones en su artículo $14^{\circ}$ precisaba que:

La concesión podrá otorgarse bajo cualquiera de las siguientes modalidades:

a) A título oneroso, imponiendo al concesionario una contribución determinada en dinero o una participación sobre sus beneficios a favor del Estado;

b) A título gratuito;

c) Cofinanciada por el Estado, con una entrega inicial durante la etapa de construcción o con entregas en la etapa de la explotación, reintegrables o no; o,

d) Mixta, cuando concurran más de una de las modalidades antes señaladas. 
Mediante esta clasificación, se aprecia que el factor determinante para ello es la inversión, ya sea a título gratuito o título oneroso por parte del Estado o del concesionario o con la participación de ambos. Es decir, es importante determinar en el contrato de concesión quién será el que asuma el costo de la inversión, y a partir de ello, se determinará la tipicidad de esta.

El artículo $15^{\circ}$ del mismo cuerpo legal establecía que "para determinar la modalidad de la concesión según el Artículo $14^{\circ}$ de este título, deberá considerarse la necesidad de la obra y del servicio, su rentabilidad, la amortización de sus costos, y de los gastos de conservación y de explotación”. Efectivamente, se deben medir y tomar en cuenta estos indicadores para elegir de manera apropiada la modalidad de la concesión a otorgarse. La necesidad de la obra y del servicio que requiere el Estado será el motivo fundamental para determinar su modalidad. Por ende, debe evaluarse cuan indispensable resulta el otorgamiento de una concesión para la construcción de nuevas obras, la culminación y mantenimiento de éstas, determinar si estas contribuirán al desarrollo económico-social de los usuarios beneficiados. Asimismo, para la atracción de capitales privados, es importante la rentabilidad que el contrato de concesión generará en el tiempo, los inversionistas optarán por participar cuanta más rentabilidad financiera se estime como retribución a ellos, puesto que al carecer de un flujo económico óptimo no resultaría interesante para el concesionario.

Al respecto, Gómez de la Torre Barrera (2001) señala que, las concesiones resultan bastante atractivas para los intereses del Estado, pues representa una utilización de las finanzas gubernamentales, hecho que trae como principal consecuencia, la limitación de la capacidad de endeudamiento fiscal y que además configura la transferencia de una serie de riesgos hacia el sector privado, liberando de los mismos al Estado (p. 72).

De lo antes señalado, se distingue que el Estado también será participe de la rentabilidad. Es decir que, las ganancias no sólo se han de generar para el concesionario, quien ejecutará lo estipulado en el contrato de concesión, sino también en relación a los intereses del propio Estado o concedente, pues al conferir ciertos derechos y obligaciones a un tercero del sector privado, el Estado ya no es responsable sobre los riesgos inherentes a dicha obra de infraestructura y/o prestación de servicios. Por lo tanto, mejora sus finanzas gubernamentales buscando beneficios para la sociedad, y sobre todo generando 
crecimiento, desarrollo, competitividad, reduciendo la pobreza y aumentando la calidad de vida de la población.

Finalmente, el artículo desarrollado establece que, debe considerarse la amortización de los costos y los gastos de conservación y de explotación. Al respecto, se debe precisar que ambas partes, concesionario y concedente, deben decidir también la modalidad de concesión, en base a una proyección de los costos y gastos implícitos y si efectivamente tendrán la capacidad de asumir los mismos, este indicador resulta importante también para determinar el plazo de la concesión, así como el modo en que se hará efectiva la recuperación económica a través de las tarifas, peajes y cualquier otra modalidad de recuperación o reinversión.

Ahora bien, las concesiones también se clasifican de acuerdo a su esquema y tenemos los siguientes:

\section{- $\quad$ Concesión BOT (Build-Operate-Transfer):}

Construir, Operar y Transferir, que implican que la inversión siempre es propiedad del concedente, no obstante que el derecho de explotación de la inversión corresponde al concesionario, durante el plazo del contrato. Normalmente se trata de bienes de uso público como pueden ser las carreteras, el aeropuerto Jorge Chávez, los puertos, entre otros. (Altamirano et al., 2010, p. 1098).

En términos generales el modelo BOT (construir, operar y transferir), es utilizado cuando existe la obra de infraestructura y esta se entrega al concesionario para un posterior mantenimiento y mejoramiento. Entonces todas estas posteriores mejoras que se realicen durante el período en que el concesionario tenga derechos sobre dicha obra de infraestructura, serán de propiedad del Estado.

- Concesión BOOT (Build-Own-Operate-Transfer):

Según Salvatierra Combina (2009), “este contrato permite que, a través de una Licitación Pública Internacional, una empresa privada construya una infraestructura nueva a cambio de recuperar su inversión en el plazo de treinta años" (p. 323). 
Construir, Detentar la propiedad, Operar y Transferir, que implican que la inversión es de propiedad del concesionario durante el plazo del contrato. En este caso se trata de bienes que no son públicos como la concesión de telefonía fija, por ejemplo, así como las redes de tendido eléctrico, entre otras, dependiendo del diseño de la concesión. (Altamirano et al., 2010, p. 1099).

Mediante los contratos de concesión bajo el esquema BOOT, una entidad construye con sus propios recursos económicos la obra de infraestructura, esta acción le atribuye al concesionario un derecho de propiedad sobre dicha construcción, posteriormente, el operario tendrá la facultad de operarla o explotarla hasta que el contrato de concesión culmine y así será transferida al Estado, quien finalmente recuperará su derecho de propiedad.

Los esquemas BOOT tienen normalmente las siguientes características:

a) Una sociedad privada construye activos de infraestructura que tradicionalmente han estado asociados con la inversión realizada por el gobierno general y las sociedades no financieras públicas;

b) Legalmente dicha sociedad es propietaria y opera esos activos por un tiempo definido $\mathrm{y}$,

c) La sociedad privada transfiere la infraestructura al gobierno al término del contrato, que usualmente tiene una vigencia inferior a la vida útil del activo (Tuesta y Polo, 2014, p. 39).

De la misma forma, la clasificación de las concesiones de acuerdo a la forma de retribución al concesionario es la siguiente:

- Las concesiones autosostenibles:

Son un tipo de concesión en la cual el concesionario es quien asume todos los riesgos inherentes a la utilización de la obra de infraestructura o del servicio por parte del mismo. En este tipo de concesión la explotación de dichas obras y servicios generan ingresos monetarios suficientes para recuperar la inversión efectuada por el concesionario y, por ende, se genera también un margen de ganancia o rentabilidad a responsabilidad de éste. Es decir, que si 
la explotación de las obras y servicios no llegan a producir suficientes ingresos para el concesionario entonces este riesgo financiero será asumido por él mismo y no por el Estado. Por lo tanto, el Estado no brinda ningún tipo de garantía financiera.

- Las concesiones cofinanciadas:

A diferencia de las concesiones autosostenibles, en este tipo de concesión el Estado tiene una participación importante mediante el otorgamiento de recursos. Es decir, ambas partes, concesionario y Estado, participan en la inversión para la explotación de las obras de infraestructura y/o prestación de servicios. Es por esta razón que, es el Estado quien asume gran parte de los riesgos, como el riesgo de explotación y el riesgo de demanda, garantizando al concesionario el pago de montos determinados. En otras palabras, si mediante la explotación de la obra de infraestructura y/o la prestación de un servicio no se llega a generar ingresos suficientes que cubran el monto de la inversión y tampoco genera por tanto un margen de ganancia óptimo, pues el concesionario no pierde la recuperación de su inversión porque el Estado será quien asuma y garantice el pago de un monto de dinero determinado al concesionario.

- Concesiones mixtas o bifurcadas:

En este tipo de concesión, se involucran ambas formas de retribución anteriormente desarrolladas. Dicho de otro modo, intervienen tanto el Estado como el concesionario; cuando por la explotación de la obra de infraestructura y/o de la prestación del servicio público, se haga efectivo el pago o la retribución con el fin de recuperar la inversión efectuada, se da lugar a la utilización del Ingreso Mínimo Anual Garantizado (IMAG) el cual es asumido y otorgado por el Estado. Por lo tanto, en esta modalidad será el Estado quien asuma parte de los riesgos de explotación y demanda. El concedente se compromete a pagarle este monto (IMAG) al concesionario y por dicho valor asumirá los riesgos que le correspondan, por su parte, el concesionario asumirá todos los riegos inherentes al ingreso que se genere y que está por encima del monto que el Estado se comprometió a pagarle (IMAG). Por ende, el concesionario asumirá los riesgos por el exceso de 
ingresos generados durante el periodo de la concesión que provienen del pago que efectúen los usuarios del bien y/o servicio otorgado en concesión, adicionales al IMAG.

Finalmente, existe otra clasificación de las concesiones, para el autor Danós Ordóñez (2006), en nuestro país, las concesiones también están sujetas a una variedad de regímenes legales, que dependen de varios factores como el tipo de bienes a concesionarse, el tipo de actividades o el nivel del Gobierno que otorga una concesión. Así para el referido autor, se tendrían las siguientes clasificaciones:

- Las concesiones de recursos naturales:

Este tipo de concesiones de recursos naturales como la minería, recursos forestales, entre otros, están reguladas por las leyes sectoriales correspondientes, las cuales estipulan el régimen de concesión de cada uno de estos recursos. Dentro de estas leyes, que recurren a la figura de la concesión se encuentran por ejemplo la Ley General de Minería, la Ley $\mathrm{N}^{\circ}$ 26848 orgánica de recursos geotérmicos, la Ley $N^{\circ} 27308$ Forestal y de Fauna Silvestre para los Recursos Forestales Maderables y no Maderables, entre otros.

- Las concesiones de servicios públicos:

Dentro de esta clasificación se encuentran actividades como la telecomunicación, electricidad o energía, saneamiento entre otros, actividades calificadas como servicios públicos que también tienen sus leyes sectoriales y son otorgadas en concesión.

- Las concesiones de obras públicas de infraestructura:

En esta clasificación se encuentran por ejemplo las obras públicas de infraestructura como carreteras, aeropuertos, puertos, entre otros que son otorgados en concesión y estaban regulados por el Texto Único Ordenado de las Normas con Rango de Ley que Regulan la Entrega en Concesión al Sector privado de las obras públicas de infraestructura y de servicios públicos, aprobado mediante Decreto Supremo $\mathrm{N}^{\circ}$ 059-96-PCM y su respectivo reglamento. (pp. 19-25). 


\subsection{Tratamiento contable de las concesiones}

Las concesiones constituyen esquemas económicamente complejos por naturaleza, al estar supeditados a diversos factores para su celebración. Por ello es que, los contratos son celebrados desde distintos puntos de vista, considerando cláusulas especiales que no son totalmente similares para todos los casos, puesto que, en ocasiones dichas cláusulas estarán sujetas a las necesidades que tenga un Estado, el beneficio que representará para el usuario, el desarrollo que generará en el tiempo, la modalidad en la que será celebrada, los costos y gastos que deberá asumirse, la forma en que deberá recuperarse la inversión, la capacidad financiera que posea un concesionario, el riesgo de demanda y explotación, entre otros. Es así como, después de haberse celebrado estos contratos, dichos conceptos tendrán efectos financieros y/o contables para el inversionista, que hasta hace unos cuantos años, no estaban regulados y dependían del criterio autónomo de cada compañía.

Sin embargo, después de un arduo trabajo efectuado por el Comité de Interpretaciones de Normas Internacionales de Información Financiera, se logró uniformizar la diversidad del tratamiento contable de las concesiones mediante la emisión de normas contables especiales. Si bien es cierto, en las concesiones el motor fundamental de estas es la infraestructura y/o servicio público entregado en concesión, también los otros aspectos establecidos en las cláusulas del contrato serán un factor determinante al momento de otorgarle el tratamiento financiero correcto. Las normas contables emitidas respecto de las concesiones son las siguientes:

- La Interpretación emitida por el Comité de Interpretaciones de Normas Internacionales de Información Financiera - CINIIF 12 Acuerdos de Concesión de Servicios.

- La Interpretación emitida por el Comité Permanente de Interpretaciones Standing Interpretations Committee, SIC 29 Acuerdos de Concesión de Servicios: Información a Revelar.

Por lo expuesto, es fundamental determinar financieramente la naturaleza del activo del operador o concesionario. Por lo tanto, a continuación, se desarrollará la clasificación contable de este, surgiendo los siguientes: activo fijo, activo intangible y activo financiero. 


\subsubsection{Reconocimiento de un activo fijo}

Al respecto, la interpretación que efectuó el Comité de Interpretaciones de Normas Internacionales de Información Financiera, CINIIF 12 Acuerdos de Concesión de Servicios (en adelante la Interpretación CINIIF 12), establece que:

Esta Interpretación no especifica la forma de contabilizar las infraestructuras que hubiera reconocido y mantuviera como propiedades, planta y equipo el operador antes del comienzo del acuerdo de servicio. A tales infraestructuras se aplican los requerimientos de baja en cuentas de las NIIF (establecidos en la NIC 16).

Vemos que la Interpretación CINIIF 12 señala que, esta norma no será aplicable cuando se haya reconocido un activo fijo al bien materia de concesión. Al respecto, las Normas Internacionales de Información Financiera han definido de manera explícita el concepto de activo fijo, es así como, para determinar si una infraestructura, sujeta a un contrato de concesión, resulta ser un activo fijo para el inversionista se tomará en cuenta lo establecido en la Norma Internacional de Contabilidad - NIC 16 Propiedades, Planta y Equipo.

Por lo tanto, esta norma señala que los bienes que se consideran financieramente como inmueble, maquinaria y equipo, los cuales representan el activo fijo de una entidad, son aquellos bienes tangibles que son utilizados con el fin de su aprovechamiento para las actividades cotidianas que realiza una empresa o entidad, y que deben ser utilizados por más de un ejercicio o periodo. Es decir que, su liquidez no debe ser menor a un año y no debe estar destinado a la venta, siendo un requisito indispensable que este bien deba ser reconocido como un activo cuando sea probable que la entidad obtenga beneficios económicos futuros derivados del mismo y que, adicionalmente el costo de este bien, calificado como activo, pueda ser valorado económicamente con fiabilidad.

Por ende, un elemento del activo fijo se reconocerá como tal financieramente en la contabilidad de la empresa, cuando concurran ambos requisitos conjuntamente. Primero que sea probable que la entidad obtenga las utilidades económicas futuras derivadas del mismo, vale decir que, mediante la explotación o usufructo de estos, obtenga rentas o ganancias futuras. Segundo, que el costo de este activo para la entidad 
pueda ser valorado con fiabilidad, dicho de otro modo, pueda ser medido financieramente con certeza. Asimismo, es imprescindible que dicho activo forme parte de la propiedad de la empresa, en otras palabras, la compañía tenga derecho a la propiedad sobre dicho bien, y con ello sea quien asuma los riesgos y beneficios inherentes a este. Es por ello, que el párrafo 4 de la NIC 16, establece que otras normas pueden obligar a reconocer un activo fijo con un tratamiento diferente como son los arrendamientos. La NIC 17 Arrendamientos, establece que la empresa debe evaluar a través de un bien otorgado en arrendamiento si este transmite los riesgos y ventajas para reconocer un activo fijo.

Al respecto, en las concesiones surgirá un activo fijo cuando el operador cumpla con los requisitos exigidos en la NIC 16 Propiedades, Planta y Equipo, anteriormente expuestos, y especialmente porque el operador recibirá por parte del concedente una infraestructura bajo las siguientes figuras: i) privatización, ii) desinversión iii) sociedad por acciones, iv) concesiones bajo la modalidad de construir-poseer-operar (BOO Build, Own, Operate), o iv) la modalidad construir-poseer-operar-transferir (BOOT Build, Own, Operate, Transfer), por ende, tendrá no solo el control de dichos activos, sino también el derecho de propiedad sobre ellos, consecuentemente, la propiedad o pertenencia total del activo la tiene el operador.

Adicionalmente, cuando el bien es reconocido como un activo fijo, la inversión del capital es otorgada por el operador y asumirá el riesgo de la demanda. Es importante notar que, la duración de este tipo de concesiones oscila entre los 25 a 30 años, o también de forma indefinida la cual puede ser limitada por la licencia, y finalmente el control sobre la participación residual la tiene el operador.

\subsubsection{Reconocimiento de un activo intangible}

La Interpretación CINIIF 12 Acuerdos de Concesión de Servicios, estableció mediante su párrafo 5 lo siguiente:

Esta Interpretación se aplica a los acuerdos de concesión de servicios públicos a un operador privado si:

(a) la concedente controla o regula qué servicios debe proporcionar el operador con la infraestructura, a quién debe proporcionarlos y a qué precio; $\mathrm{y}$ 
(b) la concedente controla - a través de la propiedad, del derecho de uso o de otra manera - cualquier participación residual significativa en la infraestructura al final del plazo del acuerdo.

Por ende, de no cumplirse con estos dos requisitos, la citada Interpretación CINIIF 12 no será de aplicación y, por tanto, será aplicable la NIC 16, reconociéndose un activo fijo como vimos en el apartado anterior.

Ahora bien, el párrafo 17 de la citada norma contable señala que:

El operador debe reconocer un activo intangible en la medida en que reciba un derecho (una licencia) a efectuar cargos a los usuarios del servicio público. El derecho para efectuarlos no es un derecho incondicional a recibir efectivo porque los importes están condicionados al grado de uso del servicio por parte del público.

Respecto del activo intangible el párrafo 26 de la Interpretación CINIIF 12, también establece que:

La NIC 38 se aplica al activo intangible reconocido según los párrafos 17 y 18. Los párrafos 45 a 47 de la NIC 38 proporcionan guías para la medición de los activos intangibles adquiridos a cambio de uno o varios activos no monetarios, o bien a cambio de una combinación de activos monetarios y no monetarios

Por lo tanto, según lo dispuesto en el párrafo 8 de la NIC 38 Activos Intangibles, "un activo intangible es un activo identificable de carácter no monetario y sin apariencia física". Asimismo, el párrafo 9 de la citada NIC también señala entre otros que:

Con frecuencia, las entidades emplean recursos, o incurren en pasivos, en la adquisición, desarrollo, mantenimiento o mejora de recursos intangibles tales como el conocimiento científico o tecnológico, el diseño e implementación de nuevos procesos, o nuevos sistemas, las licencias o concesiones, la propiedad intelectual, los conocimientos comerciales o marcas (incluyendo denominaciones comerciales y derechos editoriales).

De lo expuesto, la Interpretación CINIIF 12 estipula que se reconocerá un activo intangible, el cual se sujetará a lo dispuesto por la NIC 38. 
En ese orden de ideas, de la norma citada se debe entender que, el concesionario no recibe el derecho de propiedad sobre los bienes materia de concesión, la cual se mantiene en el concedente que es el Estado, sino más bien un derecho de uso o explotación sobre los bienes que transfiera al Estado con motivo de sus inversiones. Por ello, si el concesionario recibe un derecho contractual de efectuar cargos a los usuarios finales, dicha concesión calificará como un activo intangible.

\subsubsection{Reconocimiento de un activo financiero}

La Interpretación CINIIF 12, es de aplicación para una amplia variedad de acuerdos de concesión de servicios celebrados entre el Estado y los inversionistas privados a quienes se denomina como concesionarios y que en la presente norma contable figuran como operadores.

Las concesiones reguladas por esta interpretación son por ejemplo las concesiones de construcción de carreteras, servicios públicos aeroportuarios, escuelas, entre otros. Resulta importante señalar, que el tratamiento contable que se establezca para un acuerdo de concesión de servicios estará supeditado a los términos contractuales y las condiciones específicas de las cláusulas del contrato de concesión. Dependiendo de esta información, el concesionario podrá darle el tratamiento contable y financiero correspondiente a la concesión.

Según los párrafos 16 y 17 de esta norma contable, el operador o concesionario reconocerá tanto un activo financiero como un activo intangible, bajo ciertas condiciones y requisitos, a continuación, tenemos lo señalado respecto de los activos financieros:

El operador reconocerá un activo financiero en la medida que tenga un derecho contractual incondicional a recibir de la concedente, o de una entidad bajo la supervisión de ella, efectivo u otro activo financiero por los servicios de construcción; y que la concedente tenga poca o ninguna capacidad de evitar el pago, normalmente porque el acuerdo es legalmente exigible. El operador tiene un derecho incondicional a recibir efectivo cuando la concedente garantiza el pago al operador de (a) importes especificados o determinables o (b) el déficit, si lo hubiere, entre los importes recibidos de los usuarios del servicio público y los importes especificados o determinables, incluso cuando el pago esté condicionado 
a que el operador garantice que la infraestructura cumple con los requerimientos de calidad o eficiencia especificados.

Al respecto, el librillo digital CINIIF 12 Acuerdos de concesión de servicios guía práctica de bolsillo, (2011) señala que:

En algunos acuerdos de concesión de servicios, el operador podría tener un derecho contingente a cobrar efectivo o recibir otro activo financiero de la concedente en lugar de cobrar a los usuarios, si el uso del activo supera un determinado umbral. Si el umbral tiene sustancia económica (es decir, persiste una posibilidad real de que no se alcance), el operador no tendrá un derecho contractual incondicional a percibir efectivo y, en consecuencia, reconocería un activo intangible. Si el umbral carece de fondo económico porque la posibilidad de no alcanzarlo es remota, deberá pasarse por alto la condicionalidad y el operador reconocerá un activo financiero. (p. 25)

De lo expuesto, se deduce que el concesionario deberá contabilizar un activo financiero cuando tenga un derecho, establecido en el contrato de concesión, a recibir una suma de dinero (efectivo) por parte del Estado. Asimismo, este último tiene pocas probabilidades o prácticamente ninguna de evitar este pago, de no darse estas condiciones, el concesionario no podrá reconocer un activo financiero contablemente. Este derecho contractual de garantizarle al concesionario ciertos importes o sumas dinerarias, se puede establecer como un importe fijo, preestablecido en las cláusulas contractuales o puede darse el caso, que el concedente le otorga al concesionario la diferencia existente entre el ingreso de efectivo proveniente del pago de los usuarios beneficiarios y el monto estipulado en el contrato de concesión. Adicionalmente, se reconocerá un activo financiero, incluso cuando mediante el contrato de concesión, se establezca que la obra de infraestructura tenga que cumplir ciertos estándares de calidad o que el servicio público otorgado cumpla con ciertos niveles de eficiencia.

Por lo antes mencionado, debemos concluir que, a consecuencia del reconocimiento de un activo financiero, el concesionario contablemente podrá reconocer una cuenta por cobrar al concedente. El valor de esta cuenta por cobrar está representado por el monto que el concedente se ha comprometido a efectuar contractualmente, siendo este un monto fijo, ya establecido en el contrato de concesión. Esto representa un derecho 
contractual, mediante el cual el concesionario recibe efectivo del Estado, que calificará como un reembolso que le otorga el concedente por sus inversiones.

Según el librillo digital CINIIF 12 Acuerdos de concesión de servicios guía práctica de bolsillo, (2011), “el modelo del activo financiero no será aplicable si la concedente sólo paga cuando los usuarios utilizan el servicio o si concede únicamente un derecho a cobrar a los usuarios por el servicio" (p. 31). De ello se desprende que, se dará lugar al activo financiero aun cuando los usuarios beneficiarios no utilicen el servicio, es decir, que la demanda puede no fluir como se espera, sin embargo, frente a este reducido dinamismo el Estado tendrá un compromiso contractual con el concesionario para otorgarle efectivo.

Ahora bien, el tratamiento contable del activo financiero también está establecido en la Norma Internacional de Contabilidad NIC 39 Instrumentos Financieros: Reconocimiento y Valoración. Por su parte, le son aplicables adicionalmente otras normas de contabilidad como la NIIF 9 Instrumentos Financieros, la NIC 32 Instrumentos Financieros: Presentación y finalmente la NIIF 7 Instrumentos Financieros: Información a revelar. Por ende, una vez que el bien materia de concesión sea reconocido como un activo financiero de acuerdo a lo señalado por la Interpretación CINIIF 12, se deberán aplicar las normas adicionales señaladas anteriormente de corresponder.

Es así como, según lo estipulado en la NIC 39, el activo financiero se clasificará bajo los siguientes criterios y condiciones, como disponible para la venta, como una cuenta por cobrar o a valor razonable con cambios en pérdidas y ganancias, si así se designa en la fecha de reconocimiento inicial. Se debe puntualizar, que el concesionario podrá clasificar el activo financiero como cuenta por cobrar si se establecieron determinados montos, ahora bien, en caso se reconozca como un activo disponible para la venta, deberá calcularse el interés mediante la tasa de interés efectivo señalado por la citada NIC 39.

De lo expuesto, de acuerdo a la Interpretación CINIIF 12, el bien materia de concesión también podrá ser reconocido como un activo financiero en tanto, el operador o concesionario tenga derecho a recibir contractualmente ingresos por parte del concedente o Estado, una vez determinada la naturaleza financiera de este, le serán de aplicación las otras normas contables citadas. 


\subsection{Tratamiento tributario de las concesiones en el ordenamiento jurídico peruano}

Con el fin de tener una visión amplia del tratamiento en materia físcal de las concesiones en nuestro país, citaremos las principales normas que las regulan, así tenemos las siguientes:

- Constitución Política del Perú.

- Decreto Supremo N ${ }^{\circ}$ 059-96-PCM, Texto Único Ordenado de las normas con rango de ley que regulan la entrega en concesión al sector privado de las obras públicas de infraestructura y de servicios públicos.

- Decreto Supremo Nº60-96-PCM, Reglamento del Texto Único Ordenado de las normas con rango de ley que regulan la entrega en concesión al Sector Privado de las obras públicas de infraestructura y de servicios públicos.

- Decreto Legislativo 674, Ley de Promoción de la Inversión Privada de las Empresas del Estado y su Reglamento aprobado mediante Decreto Supremo $\mathrm{N}^{\circ}$ 070-92-PCM.

- Decreto Legislativo 758, Ley para la Promoción de las Inversiones Privadas en Infraestructura de Servicios Públicos modificada por el Decreto Legislativo $\mathrm{N}^{\circ} 839$.

- Decreto Supremo $N^{\circ}$ 132-97-EF, Reglamento de los beneficios tributarios para la Inversión Privada en obras públicas de infraestructura y de servicios públicos.

- $\quad$ Ley N $N^{\circ}$ 27867, Ley Orgánica de Gobiernos Regionales.

- Ley N²7972, Ley Orgánica de Municipalidades y Ordenanzas Municipales especiales a nivel de determinadas ciudades.

- Decreto Supremo N 015-2004-PCM, Reglamento de la Ley Marco de Promoción de la Inversión Descentralizada.

- Ley $\mathrm{N}^{\circ}$ 26805, Régimen de Concesiones para bienes de las Beneficencias Públicas y su Reglamento. 
- $\quad$ Ley $\mathrm{N}^{\circ}$ 29164, Concesiones de Patrimonio Arqueológico.

- Decreto Legislativo 1224 del Marco de Promoción de la Inversión Privada mediante Asociaciones Público Privadas y Proyectos en Activos y su reglamento Decreto Supremo No 410-2015-EF.

Respecto del ámbito aplicativo tributario, es necesario precisar que este constituye un aspecto muy importante y relevante a tomar en cuenta por parte del concesionario, pues es quien finalmente soportará toda la carga fiscal y el impacto económico que se presenta en la celebración de contratos bajo el modelo concesionario. De lo expuesto, la Constitución Política del Perú, mediante sus artículos $66^{\circ}$ y $73^{\circ}$, regula constitucionalmente el tratamiento de las concesiones con el fin de permitir que el Estado brinde ciertos derechos sobre los bienes del mismo $\mathrm{u}$ otorgue estos mediante las concesiones, promoviendo de esta manera la inversión privada.

En efecto, en la elaboración del modelo económico o presupuesto de rentabilidad del proyecto a concesionarse o ya concesionado, resulta de vital importancia determinar los costos tributarios con la finalidad de:

- Modelar todas las alternativas legalmente posibles para establecer en el tiempo los ingresos y egresos de la operación, con la finalidad de maximizar los escudos y/o "beneficios" tributarios previstos para esta actividad, entendiendo por beneficios a las normas dictadas con la finalidad de evitar inadecuadas o gravosas cargas tributarias debido a que las normas generales no responden a la naturaleza especial de estas operaciones; y diferir las cargas conforme las alternativas permitidas por nuestras leyes;

- Identificar temas no regulados adecuadamente que puedan implicar en la práctica tomar la decisión de asumir o no un riesgo de contingencia tributaria, y en todo caso poder cuantificarla; y como consecuencia de ello,

- Elegir la alternativa y presupuestar la carga tributaria. (Altamirano et al., 2010, p.1095)

Las concesiones pueden ser otorgadas a particulares o terceros por el Estado bajo distintas condiciones legales, las cuales estarán supeditadas a la normatividad fiscal 
aplicable correspondiente en nuestro país. Ahora bien, el tratamiento tributario a seguir por los concesionarios respecto de los bienes recibidos mediante la concesión está contemplado en dos dispositivos legales especiales, el Texto Único Ordenado de las normas con rango de ley que regulan la entrega en concesión al sector privado de las obras públicas de infraestructura y de servicios públicos, aprobado mediante el Decreto Supremo $N^{\circ}$ 059-96-PCM (en adelante la Ley de Concesiones) y por el Reglamento de los Beneficios Tributarios para la Inversión Privada en Obras Publicas de Infraestructura y de Servicios Públicos, aprobado por Decreto Supremo No. 132-97-EF (en adelante el Reglamento). Es preciso reiterar, que mediante la entrada en vigencia del Decreto Legislativo 1224 del Marco de Promoción de la Inversión Privada mediante Asociaciones Público Privadas en el 2015, se deroga la Ley de Concesiones a excepción del primer y segundo párrafo del artículo $19^{\circ}$ y el artículo $22^{\circ}$, es decir se deja en vigencia el tratamiento tributario establecido en dichos artículos.

El inciso e) del artículo $1^{\circ}$ del Reglamento precisa que, los Bienes Materia de la Concesión "son los bienes requeridos para la explotación de una obra pública de infraestructura o la prestación de un servicio público de acuerdo al Contrato de Concesión".

Por su parte, el artículo $22^{\circ}$ de la Ley de Concesiones, señala que:

El valor de transferencia de los bienes al Estado durante o al término de la concesión o su renovación será el valor contable de los bienes que no hayan sido totalmente depreciados. La transferencia estará inafecta de todo tributo creado o por crearse, incluso de aquellos que requieren mención específica para su inafectación o exoneración.

El concesionario podrá depreciar anualmente los bienes de la concesión de acuerdo a su vida útil, no pudiendo exceder en este caso la tasa anual de $20 \%$.

Alternativamente, podrá depreciar íntegramente dichos bienes durante el periodo que reste para el vencimiento de la concesión, aplicando para tal efecto el método lineal.

El tratamiento establecido en el segundo y tercer párrafos de este artículo es de aplicación a los activos intangibles de duración limitada derivados del derecho de uso sobre los activos transferidos al Estado. Para 
estos efectos la tasa de amortización aplicable será igual a la tasa de depreciación establecida para el bien transferido al Estado.

Según el citado artículo, cuando el concesionario finalmente transfiera los bienes materia de concesión una vez que ha culminado el plazo establecido contractualmente, dicho valor de transferencia estará inafecto de cualquier tipo de tributo, sea que éste se encuentre vigente o de aquel que pueda crearse, es decir, estará inafecta principalmente del Impuesto a la Renta. Nótese que, esta figura también constituye un tema controversial, puesto que en ciertos tipos de concesiones, cuando el concesionario retorna estos bienes al Estado no lo hace directamente a éste sino a empresas estatales de derecho privado las cuales de acuerdo a los artículos $6^{\circ}$ y $7^{\circ}$ de la Ley de la Actividad Empresarial del Estado Ley $\mathrm{N}^{\circ} 24948$, son aquellas que se crean por Ley y gozan de atributos propios de la Administración Tributaria y que están constituidas o reorganizadas como sociedad anónima de acuerdo a ley y que su capital pertenece totalmente al Estado.

En ese sentido, Altamirano et al. (2010), señalan que, "los bienes que adquiere el concesionario o las mejoras que realiza como parte de su inversión, revierten durante o al final de la concesión, no necesariamente al Estado en forma directa, sino a empresas estatales de derecho privado por ejemplo" (p. 1098). Sin embargo, para efectos del presente trabajo, no se desarrollará esta controversia con mayor amplitud.

Adicionalmente, el mencionado artículo $22^{\circ}$ también señala en su primer párrafo que, el valor a considerarse para efectuar la transferencia correspondiente al Estado es el valor contable de los bienes que no hayan sido totalmente depreciados. De ello podemos apreciar que la misma norma no hace ningún alcance adicional respecto del término "valor contable" ni del término "depreciado", por lo que a falta de una conceptualización de estos términos tanto en la misma Ley de Concesiones como en el marco jurídico tributario en general, debemos remitirnos a otras normas que permitan tener un acercamiento claro de estos términos, siendo que las normas contables son las más adecuadas para esclarecer este panorama, puesto que nos estamos refiriendo a términos netamente contables y financieros.

De la misma forma, con el fin de que el concesionario pueda recuperar la inversión efectuada, el artículo $22^{\circ}$ de la Ley de Concesiones, en su segundo y tercer párrafos, establecen que el concesionario puede depreciar los bienes de la concesión de acuerdo con su vida útil sin exceder la tasa anual del $20 \%$ o durante el periodo que reste para el 
vencimiento del plazo de la concesión o de su renovación. Seguidamente, el último párrafo del artículo $22^{\circ}$ del citado dispositivo legal, señala que el mencionado tratamiento también se aplicará a los activos intangibles de duración limitada derivados del derecho de uso sobre los activos transferidos al Estado. Para tales efectos, señala que la tasa de amortización aplicable será igual a la tasa de depreciación establecida para el bien transferido al Estado.

De lo expuesto, la Ley de Concesiones establece dos reglas especiales a tomar en cuenta, la primera es que el concesionario podrá depreciar anualmente los bienes materia de la concesión de acuerdo a su vida útil, no pudiendo exceder en este caso la tasa anual del $20 \%$, y alternativamente, el concesionario podrá optar por depreciar íntegramente dichos bienes durante el período que reste para el vencimiento del plazo de la concesión, aplicando para tal efecto el método lineal.

Como se observa, esta regla se aplica siempre y cuando se traten de concesiones mediante las cuales se transfiere el derecho de propiedad sobre los bienes materia de concesión a favor del concesionario, lo cual sucede usualmente en las concesiones clasificadas como BOOT (Build Own Operate Transfer), en las cuales el derecho de propiedad la posee el concesionario, y por ende, este último podrá aplicar lo establecido en dichos párrafos, utilizando la depreciación como un mecanismo de recuperación de su inversión, a una tasa mayor de la que es permitida en el Régimen General establecido en el Texto Único Ordenado de la Ley del Impuesto a la Renta aprobado mediante Decreto Supremo $\mathrm{N}^{\circ}$ 179-2004-EF y normas modificatorias.

La segunda regla especial establecida es la mencionada en el último párrafo del artículo $22^{\circ}$ que extiende el tratamiento desarrollado anteriormente, a las concesiones mediante las cuales no se transfiere el derecho de propiedad al concesionario sobre los bienes materia de concesión, sino solamente un derecho de uso sobre dichos bienes, permitiéndole utilizar una tasa de amortización equivalente al 20\%. Es decir que, en este último caso, el activo intangible derivado del mencionado derecho de uso tendrá una tasa de amortización igual a la tasa de depreciación que correspondería a este, de acuerdo con lo señalado en el segundo y tercer párrafo del artículo $22^{\circ}$.

Se debe observar que, la posibilidad de amortizar el valor del activo intangible que genera la transferencia de bienes al Estado efectuada mediante la ejecución de las inversiones comprometidas en un contrato de concesión permite que, exista una 
correlación entre los ingresos que generará la explotación de la misma y los desembolsos en los que el concesionario debe incurrir para generarlos. El tratamiento tributario mencionado permitiría que el concesionario determine el Impuesto a la Renta a su cargo como una forma de reflejar de manera uniforme su capacidad contributiva a lo largo del plazo de la concesión.

Es importante señalar que, este tratamiento adicional del artículo $22^{\circ}$ fue introducido por la Ley $\mathrm{N}^{\circ}$ 27156. Al respecto, mediante la exposición del Proyecto de Ley $\mathrm{N}^{\circ} 4958 / 98$, el entonces congresista Luis Chang Ching, sostuvo lo siguiente en la $18^{\text {a }}$ B Sesión del pleno del Congreso de fecha 14 de julio de 1999:

Para ser muy sencillos en la explicación, queremos decir que en la actualidad la legislación que corresponde a las concesiones solamente considera una modalidad, en la cual se da la construcción, la propiedad, la operación y la transferencia posterior de este bien al Estado después de que concluye la concesión.

En este último año, el Perú tiene la expectativa de sacar adelante una serie de concesiones que podrían atraer importantes inversiones al país. Pero estas concesiones son de una modalidad diferente a la que está establecida en la actual legislación; esto es, que las concesiones que podrían darse en el futuro son para poder construir, operar y transferir el bien al Estado, pero la propiedad del bien está permanentemente en poder del Estado.

Por esa razón, la modificación del artículo $22^{\circ}$ y el artículo $21^{\circ}$ del Texto Único Ordenado de la Ley de Concesiones tiene que incorporar esta nueva modalidad para que pueda realizarse adecuadamente todo el proceso.

Como podemos apreciar, esta modificación se efectuó a consecuencia del surgimiento de una nueva modalidad de concesiones que entraría a operar en nuestro país, puesto que el artículo $22^{\circ}$ inicialmente tenía alcance únicamente a aquellas concesiones bajo el esquema BOOT, mediante las cuales se transfería el derecho de propiedad al concesionario. Sin embargo, con el tiempo se celebrarían los contratos de concesión bajo el enfoque de cesión de derechos de uso, no transmitiéndose el derecho de propiedad y 
dando lugar a un activo intangible, susceptible de amortización, por lo tanto, resultó necesaria la incorporación de este supuesto en la Ley de Concesiones para atraer aún más la inversión privada y el concesionario no sea vea afectado.

De otro lado, el artículo $8^{\circ}$ del Decreto Supremo No. 132-97-EF, establece que, "se requerirá de un informe técnico dictaminado por profesional competente y colegiado o por el organismo técnico competente cuando la vida útil difiera de la establecida en la legislación del Impuesto a la Renta”. Por ende, en caso de no contar con este informe, la depreciación aceptada para efectos fiscales será el porcentaje máximo previsto en la Ley del Impuesto a la Renta, o 5\% en el caso de inmuebles o edificaciones, dependiendo adicionalmente del régimen estabilizado por el concesionario.

Por su parte, en el caso de contratos de concesión en los cuales lo que tiene el concesionario son activos intangibles de duración limitada derivados del derecho de uso sobre bienes transferidos al Estado, la amortización de estos deberá calcularse de acuerdo con la vida útil de los bienes de la concesión a los que estos se refieren, aunque, la vida útil de dichos intangibles debería ser determinada, en principio, considerando las normas contables, pero sin exceder en ningún caso la tasa de $20 \%$ que se establece en el artículo $22^{\circ}$.

De lo señalado en el párrafo precedente, se advierte que no existe una disposición tributaria que defina explícitamente el concepto de "vida útil" para efectos de determinar la depreciación de los bienes de la concesión, por lo tanto, es importante notar que la ausencia de una definición de este término para propósitos exclusivamente fiscales y/o tributarios, evidencia que el legislador no ha utilizado la denominada autonomía del Derecho Tributario para definir este concepto de vida útil.

Sin embargo, el concepto de vida útil proviene y/o cuenta con amplio desarrollo en las normas contables, entonces ante la ausencia de una definición tributaria de carácter específico y para la generalidad de la casuística que pudiera presentarse, resulta razonable acudir a las Normas Internacionales de Información Financiera (NIIF) para interpretar sus alcances financieros y en base a ello, darle el tratamiento tributario adecuado.

Adicionalmente, es importante mencionar que no existe alguna norma que defina los alcances de lo que debe entenderse por "período que reste para el vencimiento del plazo de la concesión" ni "plazo de la concesión” para fines fiscales, tampoco existe una 
regulación específica que establezca los alcances del plazo de los contratos de concesión con relación a aspectos tales como su prórroga o renovación distinta a la regulación establecida en el Código Civil para la celebración de contratos en general. Ante este supuesto, el Decreto Legislativo del Marco de Promoción de la Inversión Privada mediante Asociaciones Público Privadas y Proyectos en Activos, aprobado por Decreto Supremo No. 410-2015-EF regula el plazo de vigencia de los contratos, conforme a lo siguiente:

Artículo 61.- Plazo de vigencia de los contratos

61.1 El plazo de vigencia de los contratos de Asociación Público Privada se cuenta a partir de la fecha de su suscripción, y no supera los sesenta (60) años.

61.2 Para efectos del otorgamiento de ampliaciones o renovaciones del plazo, siempre dentro del plazo máximo total de sesenta (60) años, la entidad debe considerar cualquier cambio en las condiciones materiales, tecnológicas y económicas, bajo las cuales se lleva a cabo la prestación de los servicios, a fin de determinar si es pertinente el otorgamiento del plazo adicional o en su caso la convocatoria a un nuevo concurso, considerando los principios de valor por dinero y competencia así como otras condiciones previstas en los contratos respectivos o normas sectoriales que resulten aplicables. La ampliación debe formalizarse mediante una adenda.

61.3 Cuando el incumplimiento de los plazos obedeciera a acción u omisión del Estado o eventos de fuerza mayor, la ampliación del plazo del contrato de Asociación Público Privada se amplía de acuerdo con las condiciones, requisitos, formalidades y mecanismos pactados en el respectivo contrato, no siendo aplicable lo dispuesto en el numeral precedente.

Como consecuencia de lo antes mencionado, no hay una norma que señale explícitamente si el plazo de la concesión comprende tanto al plazo original de vigencia establecido en el contrato de concesión o si debe considerarse el plazo modificado de dicho contrato, en la medida que hubiera ocurrido una ampliación o renovación del 
mismo. Por lo tanto, para definir qué se entiende por plazo de la concesión, correspondería tomar en cuenta lo estipulado estrictamente en el Contrato de Concesión.

Adicionalmente, deberá considerarse la posibilidad o no de modificar su plazo, la forma en la que dicha modificación puede efectuarse y/o el momento en el que se considera efectuada, pero teniendo en cuenta, además, en forma supletoria las normas del Código Civil. Así en la medida en que, de acuerdo con lo establecido en el contrato y/o en las normas del Código Civil se efectuase una modificación del contrato, esta debería tenerse en cuenta para efectos de definir el "período que reste para el vencimiento del plazo de la concesión".

En este sentido, en el caso de contratos de concesión en los cuales el concesionario tiene activos intangibles de duración limitada derivados del derecho de uso sobre los activos transferidos al Estado, la amortización de estos se calculará considerando el periodo que reste para el vencimiento del plazo de la concesión o de su renovación atendiendo a lo estrictamente estipulado por las partes en el Contrato de Concesión y, de ser el caso, a lo señalado en el Código Civil.

En ese orden de ideas, las inversiones de capital destinadas a la adquisición o construcción de activos fijos o intangibles son recuperadas por el inversionista privado o concesionario para efectos tributarios, mediante el sistema de depreciación o amortización, según sea el caso. Por su parte, el plazo de recuperación de la inversión suele estar establecido por las normas tributarias en función a la vida útil del bien o una vida útil presumida por la Ley de tal forma que, al término de ésta, se consigue que la inversión sea recuperada totalmente y la inversión se recupera durante el tiempo que estos activos generan beneficios económicos para su titular.

Finalmente, tampoco existe norma tributaria que defina los conceptos de “depreciación” la cual está vinculada a un activo fijo, ni de "amortización” término vinculado al reconocimiento de un activo intangible, siendo necesaria la utilización de normas supletorias que contienen dichas definiciones como son las Normas Internaciones de Información Financiera.

Como pudimos analizar, el artículo $22^{\circ}$ aún vigente dentro del ordenamiento jurídico tributario peruano, se ha remitido a términos estrictamente contables para establecer el tratamiento fiscal que se aplicará al bien otorgado mediante concesión, 
resultando razonable para el concesionario la remisión a las Normas Internacionales de Información Financiera (NIIFs), las cuales rigen las pautas respectivas para considerar el bien de la concesión como un activo fijo o intangible, y así aplicar el tratamiento tributario especial para la recuperación de la inversión mediante la depreciación o amortización.

Sin embargo, nótese que esta norma tiene una vigencia de aproximadamente 20 años, tiempo en el cual, se establecieron clasificaciones adicionales de las concesiones, como por ejemplo las estipuladas en el Decreto Legislativo 1224, concesiones autosostenibles y cofinanciadas.

Por otro lado, resulta lógico que dentro del mundo financiero también surgieran cambios en las normas contables que uniformicen y abarquen la gran cantidad de casos que se presentan en la realidad financiera. Consecuentemente, al estar las normas contables supeditadas a una constante actualización y cambios con fines de mejorar el tratamiento financiero, surgen discrepancias cuando se debe aplicar las normas tributarias. En este caso, al determinar si un bien sujeto a concesión, será tratado como un activo fijo, un activo intangible u otro tipo de activos, como los activos financieros que resultan en una concesión de tipo bifurcada o mixta bajo el enfoque de la Interpretación CINIIF 12 Acuerdos de Concesión de Servicios que entró en vigencia en el Perú en el 2011, apartándose del ámbito de aplicación de una norma tributaria que ha quedado corta en su tratamiento, conllevando a la inseguridad jurídica para el concesionario.

\section{CAPÍTULO II: CONCESIONES BIFURCADAS O MIXTAS}

\subsection{Concesiones Bifurcadas o Mixtas}

En el capítulo anterior, se ha señalado que las concesiones se clasifican de acuerdo a distintos criterios como son, el tipo de reinversión, el tipo de esquema, de bienes, de actividades, y también la forma de retribución al concesionario. Dentro de esta última, se encuentran las concesiones mixtas o bifurcadas que son el resultado de la combinación de dos modalidades conocidas como concesiones autosostenibles y concesiones cofinanciadas en las que el riesgo de la explotación y el riesgo de demanda son asumidos por el concesionario y el concedente respectivamente. 
Tuesta y Polo (2014) manifiestan al respecto que:

[Las] concesiones [en las] que [se] involucren ambas formas de retribución, a las que se denomina usualmente concesiones mixtas o bifurcadas y donde el Estado asume parte del riesgo, usualmente a través de la figura del IMAG o Ingreso Mínimo Anual Garantizado, es decir, el concesionario sólo asume el riesgo por la generación de ingresos por el exceso de la suma que el Estado se ha comprometido a pagarle. (p. 40)

Es importante notar que, en esta clasificación un factor determinante para calificar el contrato de concesión bajo la modalidad de bifurcada o mixta, es definir que el riesgo de demanda y/o explotación será asumido conjuntamente por ambas partes involucradas en el contrato, es decir por el Estado (concedente) y el tercero inversionista privado nacional o internacional (concesionario). Esta distribución del riesgo entre ambos sujetos involucrados en la concesión contribuirá a que la retribución económica que espera percibir el concesionario a lo largo del periodo de la concesión sea más rentable.

Por lo tanto, ello conlleva a que, sean partícipes y responsables de la demanda, tanto el Estado, como el tercero privado. Es decir que, al momento de producirse la explotación o usufructo de la infraestructura y/o prestación del servicio público, y el concesionario efectúe el cobro o percepción de la retribución a los usuarios finales, con el fin de recuperar la inversión, el riesgo de demanda deberá ser compartido por ambas partes contractuales.

Respecto del riesgo, Barrantes Cáceres (2012) señala que "un contrato de concesión para el desarrollo de infraestructura es un acuerdo para compartir riesgos. Desde la economía, el riesgo es la medición de incertidumbre" (p. 211).

Esta novedosa modalidad contractual de las concesiones, clasificadas como bifurcadas o mixtas son celebradas en razón de que, previamente, durante la etapa de la elaboración del proyecto de inversión, se tiene amplio conocimiento de que la construcción de la obra de infraestructura y/o la prestación del servicio público tendrá un costo económico muy significativo y que el retorno de la inversión no será normalmente dinámico. El concesionario tendrá dificultades en la recuperación financiera de su inversión durante la etapa de explotación, por lo que, existe el riesgo de que las utilidades no fluctúen como se espera con la explotación del bien y/o servicio público por sí mismos 
mediante el pago que realicen los usuarios beneficiarios a través de los mecanismos de recuperación de la inversión como los peajes, tasas, tarifas, entre otros.

Por ejemplo, estas dificultades en la recuperación de ganancias para el concesionario pueden presentarse en las concesiones celebradas para la construcción de autopistas a lo largo del territorio nacional y que se encuentren en zonas de escasa concurrencia vehicular en determinados periodos o que estén sometidos a hechos fortuitos como los desastres naturales, eventos que influirán drásticamente en la recaudación de los ingresos esperados. Existe un riesgo importante que afectará la demanda, por ello, este riesgo de demanda es asumido conjuntamente por el concedente y concesionario.

Atendiendo a ello, resulta imprescindible para el concesionario que, ante este eventual riesgo económico al que está expuesta su rentabilidad, se estipule contractualmente una cláusula en la que se garantice, cuando menos, ingresos mínimos que serán otorgados por el Estado y que el concesionario percibirá anualmente, estos ingresos asegurados resultarán útiles para cubrir no sólo la recuperación de los costos involucrados durante la etapa de construcción, sino aquellos destinados al mantenimiento y reparaciones involucrados. Por ello el Estado le garantiza al concesionario un valor mínimo de ingresos mediante una figura económica llamada Ingreso Mínimo Anual Garantizado (IMAG).

Por un lado, el Estado asume una responsabilidad económica frente al concesionario, mediante el pago de determinados ingresos que estén destinados a la recuperación de la inversión para el concesionario, por este motivo, el concedente asumirá el riesgo de explotación y demanda utilizando usualmente la figura del IMAG. En otras palabras, se compromete contractualmente con el concesionario a proporcionarle un monto concreto de ingresos, pese a que durante el proceso de explotación no se alcance a cubrir este monto con lo recaudado a los usuarios finales. Es obligatorio que el Estado cumpla con otorgarle esta suma monetaria al concesionario.

Ahora bien, la otra parte del riesgo de demanda y/o explotación es asumido por el propio concesionario a través de los ingresos generados por los usuarios del bien y/o servicio público entregado en concesión, esta figura se produce cuando, por la explotación del bien y/o servicio público materia del contrato de concesión, se generan ingresos o ganancias que superan el monto de ingresos garantizado por el Estado 
contractualmente, será el concesionario el que asume el riesgo, vale decir será responsable de los ingresos que fluctúan sobre el valor del IMAG. Consecuentemente, será el concesionario quien asuma los riesgos de demanda por ese diferencial que es pagado por los ciudadanos usuarios del bien y/o servicio concesionado.

Como se puede apreciar, para que califiquemos un contrato de concesión como bifurcado o mixto se debe analizar el contenido del mismo respecto de la recuperación económica y determinar en base a este análisis si el riesgo de demanda y/o explotación será compartido entre el concedente y el concesionario conjuntamente. Como mencionamos esta determinación se efectuará mediante un análisis a las cláusulas económico-financieras del contrato, que establecen las condiciones en las que el concesionario percibirá los ingresos correspondientes, una parte garantizada por el Estado y la otra por la demanda de los usuarios. A partir de ello, se estaría estipulando la participación de ambas partes en el señalado riesgo.

Al respecto, Baca y Ortega (2013) señalan:

Debe tomarse en cuenta el principio de asignación adecuada del riesgo, según el cual “deberá existir una adecuada distribución de los riesgos entre los sectores público y privado. Es decir, que los riesgos deben ser asignados a aquel con mayores capacidades para administrarlas a un menor costo, teniendo en consideración el interés público y el perfil del proyecto" (p. 46)

En términos generales, y como señalamos en párrafos anteriores, este tipo de cláusulas contractuales son estipuladas cuando se tiene conocimiento de que el retorno de la inversión no será la óptima si solamente una de las partes asumiera el riesgo en cuestión, puesto que, la recuperación de la inversión tendrá una influencia significativa de factores externos que no la hacen adecuada. Por lo tanto, para que este tipo de proyectos con riesgos económicos significativos resulten más atractivos al inversionista, se asegura que este último recupere su inversión mediante el ingreso que el Estado se obliga contractualmente a otorgarle y, adicionalmente, en caso los hubiere, se beneficiará de los ingresos adicionales que se produzcan por la explotación del bien y/o servicio público, asumiendo de esta manera el riesgo por dicha parte. 
Cabe hacer mención de que, en el hipotético caso en que, durante la fase de explotación del bien y/o servicio público otorgado en concesión, no se generasen ingresos adicionales al monto del IMAG, y el concesionario reciba como contraprestación únicamente el ingreso que el Estado ha garantizado, la naturaleza de la tipificación de la concesión no variará. Ello en mérito a que, del análisis de las cláusulas económicofinancieras estipuladas en el contrato, se tiene conocimiento previo de que se trata de una concesión donde el riesgo de explotación y/o demanda será asumido por ambas partes contractuales, concedente y concesionario y, por ende, la modalidad del contrato de concesión aún será bifurcada o mixta.

\subsection{Garantías otorgadas por el Estado en las concesiones}

Los contratos de concesión deben respaldar que el proyecto de inversión resulte rentable para los terceros inversionistas privados nacionales o extranjeros. Garantizar de forma adecuada el flujo de ingresos es uno de los aspectos primordiales al evaluar la rentabilidad que percibirá el concesionario, puesto que están sujetos a riesgos que afectarán el nivel de ingreso estimado. Para asegurar que esta fluctuación no sea impactada significativamente, se establecen en los contratos ciertas garantías que el concedente debe otorgar en favor del concesionario.

Barrantes Cáceres, (2009) señala que, “como uno de los mecanismos para fomentar las inversiones en infraestructura, se puede mencionar el establecimiento de garantías con el fin de proveer soporte financiero al inversionista cubriéndolo de distintos riesgos que podrían afectar los beneficios netos percibidos" (p. 332).

De lo expuesto, en este tipo de contratos de concesión, mediante el cual el concesionario invierte una ingente cantidad de dinero y espera recuperar esta inversión haciendo frente a los riesgos potenciales, el Estado entra a tallar este posible riesgo, asumiendo una responsabilidad financiera contractual, y así asegurándole al inversionista el retorno de la rentabilidad, puesto que de no existir estas garantías, el inversionista verá vulnerable su fluctuación de ingresos y por ende, el proyecto de inversión no le resultará atractivo. 
Asimismo, Barrantes Cáceres (2009) añade que, "ante el riesgo de que la demanda sea menor a la proyectada, el gobierno puede comprometerse a asegurar bajo algún mecanismo que la empresa reciba un mínimo de ingresos” (p. 331).

Por lo tanto, en las concesiones de tipo bifurcadas o mixtas, el concedente le garantiza al concesionario un monto fijo de ingresos para recuperar la inversión efectuada por la explotación de la infraestructura pública y/o la prestación de servicios públicos. Estas garantías se encuentran clasificadas dentro de las garantías no financieras que otorga el Gobierno con la finalidad de mitigar los riesgos que se pueda presentar en la recuperación de la inversión. Entre ellas y para el desarrollo del presente trabajo de investigación, se encuentra el Ingreso Mínimo Anual Garantizado (IMAG). Por su parte, el Estado también puede asumir otra garantía que es bastante similar al IMAG, la Demanda Mínima Anual Garantizada (DMAG).

\subsubsection{Ingreso Mínimo Anual Garantizado (IMAG) y Demanda Mínima Anual Garantizada (DMAG)}

Respecto a estos compromisos asumidos por el Estado, Cornejo Díaz (2006), ha manifestado que, "garantizar Ingresos Mínimos Anuales: consiste en garantizar al concesionario un nivel fijo de ingresos anuales, es decir, si en un año la demanda genera un nivel de ingresos menores a los Ingresos Mínimos Anuales, el Estado cubrirá la diferencia" (p. 225).

Ciertamente, el IMAG contractualmente es una figura de garantía que es utilizada en los contratos de concesión de tipo bifurcados o mixtos, y es asumido por el Estado (concedente). Esta garantía no sólo permite que el proyecto de concesión se vea más atractivo a los concesionarios, quienes proporcionan tecnología, financiamiento, capacidad, eficiencia, entre otros, sino también permite que se reduzcan los riesgos de demanda y pago. Por lo que, en caso la demanda de la concesión (ingresos aportados por los usuarios de la infraestructura) no sea suficiente para cubrir la rentabilidad proyectada, los costos de mantenimiento y/o reparaciones, el Estado será quien le retribuya un monto específico al concesionario. En otras palabras, en caso de que los ingresos anuales generados por la explotación de la concesión sean inferiores al ingreso mínimo anual 
garantizado del año que ha sido establecido contractualmente, el Estado cubrirá esta diferencia acorde a lo que se haya pactado en el contrato correspondiente.

Esta figura económica está textualmente estipulada en un contrato de concesión de tipo bifurcado o mixto, es decir previamente a la etapa de construcción y/o explotación, se tiene conocimiento de que, en un eventual riesgo en la fluctuación de ingresos, el Estado cubrirá este riesgo con los pagos efectuados al concesionario, asegurándole los ingresos que proyectaba percibir. Por más que, en alguno de los años de concesión, el concesionario reciba ingresos que superen este IMAG, generados por la eficiente demanda de los usuarios beneficiarios finales y no sea necesario que el Estado le retribuya económicamente diferencia alguna, ello no desnaturaliza que el contrato haya estipulado esta garantía textualmente.

Ahora bien, Tassara et al. (2009), señalan que:

El IMAG y DMAG son garantías que otorga el Estado a favor del concesionario por las cuales se compromete a garantizar a este último un nivel mínimo de ingresos. Así el IMAG garantizará en forma directa un importe mínimo que deberá percibir el concesionario, mientras el DMAG garantizará una demanda mínima del servicio a una tarifa determinada, asegurando así, en última instancia, un nivel mínimo de ingresos.

En cualquiera de estos esquemas, si por cualquier variable los ingresos o la demanda bajaran y no se alcanzara al final del ejercicio el ingreso o demanda mínima garantizada, el Estado estará obligado a cubrir la diferencia derivada del flujo de ingresos efectivamente percibidos, y el flujo de ingresos garantizados. En rigor, no existen diferencias sustanciales entre el IMAG y la DMAG siendo que la utilización de uno u otro dependerá del tipo de proyecto en el cual se vaya a implementar. (p. 154).

Como podemos observar, estas garantías se activarán cuando la fluctuación de ingresos no sea óptima. Se debe tener presente que el IMAG es un tipo de garantía que se utiliza usualmente en los contratos de concesión de infraestructura de carreteras es decir en el sector transporte, puesto que los ingresos que fluctúan en ellas son variables y como vimos en apartados anteriores, están expuestos a un mayor riesgo, el mecanismo 
de ingreso utilizado en este caso es el peaje, el cual es vulnerable a riesgos en su recaudación como pueden ser los conflictos sociales (bloqueos de carretera), entre otros.

Respecto del procedimiento de reconocimiento del IMAG, Tassara et al. (2009) concluyen en que:

Ahora bien, los Contratos de Concesión no se limitan a establecer la existencia de un IMAG o una DMAG, sino que también regulan un procedimiento de reconocimiento de los mismos... en la mayoría de las concesiones viales, el procedimiento de reconocimiento del IMAG es el siguiente:

a) Mensualmente el concesionario debe enviar un informe al regulador (en este caso, OSITRAN), sobre la recaudación por concepto de peaje. El regulador evaluará el informe pudiendo hacer observaciones al mismo.

b) En los primeros quince (15) días del mes de enero de cada año, el regulador hará una contabilización anual de los ingresos recaudados por peaje del año anterior.

c) En caso [de] que la recaudación anual por peaje sea menor al IMAG del mismo año, entonces el monto dado por diferencia entre el IMAG y la recaudación anual por peaje deberá ser presupuestado por el concedente en el Proyecto de Ley del Presupuesto General de la República para el siguiente ejercicio presupuestable. (p. 155)

Por lo expuesto, vemos que el Estado Peruano mediante esta figura económica llamada Ingreso Mínimo Anual Garantizado (IMAG), asume una parte del riesgo de la demanda y/o explotación y le garantiza al concesionario una rentabilidad estable a lo largo de la vigencia del contrato de concesión o durante el periodo que se estime deba aplicarse este IMAG. Adicionalmente, estos ingresos garantizados por el Estado y que percibirá el concesionario deben encontrarse preestablecidos en las cláusulas económicofinancieras de los contratos de concesión. Este monto de ingresos garantizados se fija bajo diversos criterios, por ejemplo, se puede determinar un monto lineal y constante en el tiempo, o puede ser el resultado de ciertos parámetros porcentuales que fluctúen con los años de explotación, vale decir, no necesariamente debe ser un valor constante, puede 
ser variable con el paso de los años, incrementando su cuantía a medida que se va explotando el bien concesionado.

Al respecto Cornejo Díaz (2006) manifiesta que, "el contrato permite llevar a mayor profundidad los aspectos técnicos, legales y financieros definidos en las Bases, estableciendo el "cómo" se desarrollará la concesión durante los años que ésta dure" (p. 220). Adicionalmente, Barrantes Cáceres (2009) también señala que, “con concesiones, entonces, el mecanismo para asegurar una rentabilidad privada aceptable es el de constituir garantías. Así, se reduce el riesgo y se hace atractiva la inversión” (p. 332).

Por ende, tanto para el concedente y el concesionario resulta de vital importancia que las cláusulas del contrato de concesión se establezcan con la mayor claridad posible. El Estado, al estar en búsqueda constante de financiamiento privado, debe atraer la inversión a través de garantías interesantes para el concesionario, con las cuales, este último, tenga un panorama efectivo de todos los detalles económicos y financieros involucrados como son los gastos, costos, flujos de caja, ingresos, los mismos que se presentarán durante el periodo de tiempo que dure la concesión. Con mayor razón porque estas modalidades de financiamiento tienen una duración extensa en el tiempo que, según las normas emitidas sobre la materia, no debe exceder los 60 años como plazo máximo.

Es de suma importancia que los términos del contrato abarquen lo más posible todas las contingencias que se puedan presentar y así estimar con mayor precisión cual será la fluctuación financiera para la recuperación de la inversión, es decir la rentabilidad.

El autor, Cornejo Díaz (2006), también sostiene que:

El contrato debe también asegurar la "bancabilidad" del proyecto. Asegurar que un proyecto sea "bancable" significa que las inversiones a ser realizadas sean financiables a nivel nacional o internacional y esto se logra garantizando el flujo de ingresos que servirán para el repago de la deuda. (p. 224)

Es conveniente notar que, uno de los aspectos más relevantes para que un inversionista tome la decisión de participar en el desarrollo del proyecto de infraestructura y/o prestación de servicios públicos, es la ganancia o rentabilidad que ha de generar con la explotación del bien o servicio concedido, por lo que, si el contrato respalda todas las situaciones posibles de coyuntura que puedan afectar este aspecto, el 
concesionario será partícipe de la ejecución y usufructo. Adicionalmente, es necesario distinguir que existen muchos factores de riesgo en una concesión, que puede afectar a ambas partes, concesionario y concedente, desde factores políticos hasta factores sociales y económicos, los que conllevan a que el contrato se celebre contemplando las garantías posibles que contribuyan a mitigar los posibles efectos e impactos y reducir los riesgos.

Por su parte, Tassara et al. (2009) señalan que, “así, entre otros elementos, todo contrato de concesión debe regular los mecanismos que permitan garantizar al concesionario el acceso que tendrá a las tarifas, peajes, precios u otros sistemas que permitan la recuperación de su inversión" (p. 153). Al respecto, coincidimos con lo expuesto, en razón de que las concesiones se celebran con la finalidad de que el tercero privado nacional o internacional invierta en la construcción de obras y prestación de servicios públicos, a cambio de que, al momento de la explotación de los mismos, se garanticen y fijen los mecanismos de recuperación de esta inversión, mediante el cobro de peajes, tarifas, entre otros.

Por lo tanto, en las concesiones de tipo bifurcadas o mixtas, los contratos de concesión se celebran incluyendo estas garantías particulares denominadas Ingresos Mínimos Anuales Garantizados o IMAG, puesto que, los mecanismos de recuperación de la inversión anteriormente señalados no cubrirán la demanda requerida. En tal supuesto, el Estado se hará cargo del cumplimiento de este obligatoriamente, mientras que, si los ingresos cobrados superasen este monto mínimo, esta recaudación adicional al IMAG, será susceptible de responsabilidad del concesionario. Consecuentemente, el riesgo de demanda y/o explotación será compartida por el concedente y el concesionario.

En lo concerniente, Nalvarte Salvatierra (2017) señala que:

Cabe recordar que bajo el marco del TUO de Concesiones se otorgaron importantes proyectos como la Red Vial 5 y la Red Vial 6. En ambos proyectos se introdujeron garantías de ingreso mínimo (denominadas IMAG: Ingreso Mínimo Anual Garantizado), con la finalidad de mejorar la bancabilidad de los proyectos. (p. 369)

A continuación, se detalla un ejemplo de una cláusula contractual referente al IMAG, correspondiente al Contrato de Concesión de La Autopista del Sol Tramo 
Trujillo-Sullana (2009), el numeral 10.2 del Capítulo X: Régimen Económico Financiero del contrato señala:

El CONCEDENTE se compromete a asegurar al CONCESIONARIO, durante el periodo que resulte menor entre: (i) Quince (15) años desde la fecha de aceptación de la totalidad de las Obras o, (ii) el plazo correspondiente al repago de la deuda del CONCESIONARIO, un nivel de ingresos mínimos anuales por Peaje, conforme se indica en los párrafos siguientes. El pago del IMAG en caso se active, se efectuará a través de fondos provenientes del CONCEDENTE conforme a lo establecido en la Cláusula 10.4.

Finalmente, Barrantes Cáceres (2009) manifiesta que, "con concesiones, entonces, el mecanismo para asegurar una rentabilidad privada aceptable es el de constituir garantías. Así se reduce el riesgo y se hace atractiva la inversión” (p. 332).

No cabe duda, que el tercero privado tendrá un mayor interés en invertir en los proyectos del Estado, al advertir que su rentabilidad se encuentra respaldada, frente a los riesgos de demanda que se puedan presentar en los años de explotación de la concesión.

\subsection{Planteamiento del problema}

Desde el punto de vista económico, el marco legislativo en el cual se desenvuelve un contrato de concesión debe ser lo más atractivo posible en cuanto a reducción de riesgos se refiere, con el fin de lograr una provisión continua, sostenible y eficiente de infraestructura al país. Los inversionistas deciden traer sus fondos económicos e invertirlos en los proyectos de desarrollo del Estado, cuando tienen conocimiento de que la normativa nacional que los respalda es las más conveniente y ante todo estable, permitiéndoles generar las ganancias que estimen óptimas. La decisión de inversión está directamente relacionada con la rentabilidad que se espera obtener.

Al respecto, Barrantes Cáceres (2009) ha señalado, que "el compromiso de un empresario privado con un determinado proyecto responde a la rentabilidad de éste. La rentabilidad, a su vez, responde al riesgo que el proyecto presente" (p. 332). 
Por lo tanto, el marco legislativo tributario aplicable a las concesiones, también es uno de los motivos principales que toma como referencia el inversionista para decidir si lleva a cabo el proyecto de concesión. Este conjunto de leyes fiscales debiese tener como propósito el incentivar a los concesionarios a apostar por la inversión en el país. De modo que, es deseable que las normas tributarias relacionadas a la concesión estén constituidas de forma apropiada, para que incluyan dentro de su ámbito de aplicación a la múltiple tipología de contratos en los cuales se encuentra una gran diversidad de condiciones económicas.

Por su parte, Cornejo Díaz (2006) señala que:

En la doctrina se ha establecido que todo Contrato de Concesión debe contener un mínimo de cláusulas a las cuales se les ha denominado "el núcleo duro", entre las cuales se encuentran las obligaciones de las partes (concedente y concesionario), régimen de infracciones y sanciones, mecanismos de ajuste de contrato, aspectos económicos (tarifas, cálculo de contribuciones al Estado, criterios para reconocimiento de inversiones, mecanismos co-pago y cofinanciamiento, aspectos financieros (tratamiento del endeudamiento) garantías, régimen de resolución de conflictos y caducidad del contrato. (p. 223)

En ese orden de ideas, en el capítulo anterior se desarrolló el marco legislativo tributario relacionado a las concesiones en general, poniendo especial atención al artículo $22^{\circ}$ del Decreto Supremo Nro. 059-96-PCM, aún vigente. La redacción de este artículo se remite a conceptos netamente contables, en consecuencia, al carecer la norma tributaria de definiciones específicas para estos conceptos, se aplicarán supletoriamente las normas contables. Así pues, para aplicar el artículo $22^{\circ}$, es indispensable analizar el contrato bajo un enfoque contable o financiero y posteriormente a partir de este resultado, se determinará si el mismo se encuentra dentro del ámbito de aplicación del artículo $22^{\circ}$.

Por lo tanto, en esta cadena de análisis, el factor principal será el contenido del contrato y su correspondiente tratamiento contable. Lo preocupante de este procedimiento es que el artículo $22^{\circ}$ podría resultar inaplicable, puesto que las normas contables están en constante modificación con fines puramente financieros, buscando una mejoría continua en el tratamiento contable de las operaciones de una entidad, en contraste con el escaso dinamismo que tienen las normas tributarias en nuestro país, como 
es el caso de este artículo que ha quedado desfasado en el tiempo. Debemos recalcar que esta norma entró en vigencia el año 1996 y la única modificación que ha tenido se dio en el año 1999 ampliando su ámbito de aplicación.

Adicionalmente a la remisión de las normas contables, se encuentra el tratamiento económico de las concesiones que también ha evolucionado con el pasar del tiempo, originando, entre otros, nuevas formas de clasificación, por lo que hoy en día encontramos una tipología variable, siendo una de ellas las concesiones bifurcadas o mixtas. Por lo expuesto, frente a estos aspectos de escasa actualización, de ausencia de definiciones tributarias y de remisión a normas supletorias como las contables, la redacción del artículo $22^{\circ}$ del Decreto Supremo 059-96-PCM, ha quedado como una normativa de aplicación parcial para las concesiones bifurcadas o mixtas, generando desventajas sustanciales para los inversionistas en su rentabilidad.

\subsubsection{Limitaciones en la aplicación del artículo $22^{\circ}$ del Decreto Supremo $\mathrm{N}^{\circ} 059$ - 96-PCM}

Para ser de aplicación lo establecido en el artículo $22^{\circ}$ del Decreto Supremo 059-96-PCM o Ley de Concesiones, como beneficio tributario para el concesionario, la citada normativa ha limitado su alcance, restringiendo su aplicación exclusivamente a aquellos activos (bienes materia de la concesión) que califiquen ya sea como activo fijo o activo intangible. Ello ha originado que se deje fuera del ámbito de aplicación a aquellos bienes materia de concesión que no se encuentren dentro de estos dos conceptos.

Mediante este artículo de la Ley de Concesiones se determinó un tratamiento fiscal especial para la depreciación de los bienes involucrados en la concesión, otorgándoles una tasa distinta de depreciación que asciende al $20 \%$ anual y por ende un plazo diferente al que se encuentra regulado en el régimen general del Impuesto a la Renta. Vale decir que, se ha modificado el tratamiento general de la depreciación sólo para este tipo de activos que estén dentro del marco contractual de una concesión.

Por su parte, también se ha incluido dentro de este apartado el tratamiento correspondiente a aquellas concesiones en las cuales se reconozca un activo intangible, otorgándole igualmente una tasa de amortización idéntica al de la depreciación de los 
bienes sujetos a concesión fijado en dicho artículo $22^{\circ}$, y, por lo tanto, estableciendo un plazo de amortización igual al plazo de depreciación especial.

El dispositivo legal en mención se remite a dos términos contables, cuyas definiciones no están reguladas explícitamente en el ordenamiento jurídico tributario peruano. Por lo tanto, resulta imprescindible remitirnos a las normas supletorias al respecto, como son las normas contables, que nos servirán de guía para determinar cuándo se está frente a un activo que califique como fijo o intangible, también nos ayudarán a determinar en qué momento surgen los conceptos de depreciación y amortización relacionados a dichos activos.

La remisión facultativa a las normas contables se debe a que, la determinación de los impuestos en general como el caso del Impuesto a la Renta, tienen como base los resultados contables de una entidad, y será que a partir de dichos resultados se efectúan los ajustes tributarios que correspondan. Al respecto, el Tribunal Fiscal mediante la RTF $\mathrm{N}^{\circ}$ 010577-8-2010 resuelve un caso de controversia señalando que, "para la determinación del Impuesto a la Renta, los hechos y transacciones deben contabilizarse, en principio, de acuerdo con lo previsto por las normas contables, para luego realizar las conciliaciones respectivas con las normas tributarias que rigen determinadas operaciones".

Ahora bien, una vez que el bien materia de concesión se haya clasificado como activo fijo o intangible de acuerdo a la naturaleza financiera del contrato de concesión bajo la diligencia de las normas contables, se aplicará lo señalado en el artículo $22^{\circ}$ de la Ley de Concesiones siempre que se haya determinado la existencia de dichos activos. En otras palabras, el artículo $22^{\circ}$ de la Ley de Concesiones, al remitirse expresamente a conceptos contables como depreciación y amortización, que son dependientes de la existencia de dos activos, fijos e intangibles, ha limitado su tratamiento especial al bien y/o servicio cedido en concesión que se clasifique contablemente como estos dos activos. Por lo tanto, si contablemente se le diera otro tratamiento al bien materia de concesión, y no califica como activo fijo o activo intangible, el resultado no estará sujeto al beneficio otorgado en el artículo $22^{\circ}$.

Respecto de la inaplicación del citado artículo $22^{\circ}$, Tuesta y Polo (2014) señalan: 
En efecto, la depreciación o amortización requieren necesariamente que el contribuyente sea titular de un activo, fijo o intangible, respectivamente, por lo que, de no existir estos elementos, la norma citada resultará inaplicable, y para ello, a falta de una definición expresa de estos conceptos, debemos remitirnos a las normas contables. (p. 41)

Coincidimos con lo expuesto por los autores, en atención a que, si el bien materia de concesión no se encuentra dentro de dicho parámetro, no le será aplicable el beneficio especial establecido en el artículo $22^{\circ}$ de la Ley de Concesiones para la recuperación de las inversiones de los concesionarios mediante la depreciación o amortización utilizando una tasa diferenciada y en un plazo distinto al establecido en la ley general tributaria.

La mencionada norma de beneficio tributario claramente presenta una falencia en su redacción. Dado que cuando fue establecido, estuvo enfocado únicamente en aquellos casos en los que se celebraron contratos de concesión bajo dos modelos en específico: i) el modelo BOOT (Build, Own, Operate, Transfer) mediante el cual el Estado no solo otorgaba ciertos derechos de uso al concesionario, sino adicionalmente otorgaba el derecho de propiedad al tercero privado nacional o extranjero, por lo tanto, la propiedad se transferirá durante un plazo determinado al concesionario y ii) el modelo BOT (Build, Operate, Transfer) que consiste en la construcción, operación y transferencia del bien materia de concesión, en este tipo de concesión el Estado le otorga ciertos derechos de uso sobre el bien al concesionario, sin que se desprenda de su derecho de propiedad. Por lo tanto, el concesionario, adquiría bajo estos dos modelos concesionarios un activo fijo $\mathrm{y}$ un activo intangible.

Respecto de este tema, Nalvarte Salvatierra (2011) opina lo siguiente:

De acuerdo a lo señalado expresamente por la norma, el concesionario puede depreciar los bienes materia de la concesión. Como se sabe, en una concesión tipo BOT el concesionario nunca adquiere la propiedad de los bienes otorgados en concesión, a diferencia de una concesión del tipo BOOT.

Dado que el artículo $22^{\circ}$ no hace distinción se podría interpretar que todo concesionario por el sólo hecho de serlo, tiene derecho a depreciar 
los bienes materia de la concesión, aun cuando el concesionario no fuere propietario de los bienes otorgados en concesión. (p. 87)

Por su parte, Tuesta y Polo (2014), señalan que:

Nótese que el hecho de que contractualmente se indique que el pago al concesionario se financiará con los ingresos del servicio (peajes, tarifas, etc.) no resulta relevante si es que el Estado se ha comprometido a que el concesionario reciba siempre una suma mínima, ya que ello revela que es el Estado quien asume el riesgo. (p. 43).

Referido a este contexto señalado por los autores Tuesta y Polo, resulta de sustancial interés evaluar los riesgos propios de la concesión para determinar si estamos ante un tipo de concesión en la que se debe reconocer un activo fijo o intangible. De ese modo, se podrá determinar que el concesionario será quien asuma todos los riesgos inherentes a la concesión, tales como los riesgos de demanda y/o explotación, que se presenten durante el proceso de construcción, mejoramiento y/o mantenimiento de una infraestructura o prestación de servicio público. De ser así y no existiese participación por parte del Estado en estos riesgos, estamos ante un tipo de concesión en el cual, la responsabilidad de fluctuación de ingresos le corresponde enteramente al concesionario, pese a que estos ingresos no alcancen los niveles estimados de rentabilidad que estimó el inversionista, el Estado no está obligado a compensar esta situación. Por esta razón, en este tipo de concesiones el concesionario podrá reconocer un activo fijo o un activo intangible.

Lo contrario sucede si es el Estado quien también tiene una participación en los riesgos de demanda y/o explotación, puesto que la responsabilidad de fluctuación de ingresos no será exclusiva del concesionario, así en caso, se recaude ingresos inferiores a los niveles de demanda estimados, el Estado podrá resarcir un determinado valor monetario ante este riesgo. Sin embargo, bajo este enfoque del riesgo asumido por el concedente, no se precisará la existencia de un activo fijo o intangible.

Lo manifestado se evidencia por ejemplo en la celebración de los contratos de concesión bajo el modelo de autosostenibles en los que, el concesionario es quien asume todos los riesgos inherentes al bien materia de concesión, puesto que, en este tipo de concesiones la explotación o usufructo de dichas obras y servicios generan ingresos 
monetarios suficientes para recuperar la inversión efectuada por el concesionario y será éste quien asuma todos los costes y se haga cargo de la recuperación del capital invertido, por ello, en estos casos se podrá determinar que estamos frente a un activo fijo o intangible, siéndole aplicable en todos sus extremos el beneficio otorgado en el artículo $22^{\circ}$ de la Ley de Concesiones.

Entonces resulta que, en las concesiones bifurcadas o mixtas serán partícipes conjuntamente de los riesgos de demanda y explotación, tanto el concedente como el concesionario. De una parte, el Estado asumirá el riesgo de demanda a través del pago de un monto fijo al concesionario, el cual técnicamente es conocido como Ingreso Mínimo Anual Garantizado (IMAG), mientras que, de otro lado, si el bien materia de concesión genera mayores ingresos al monto que el Estado se ha comprometido a pagar al concesionario, entonces será por esa diferencia que el concesionario asumirá todos los riesgos de demanda y explotación.

Por ende, respecto del monto asumido por el concesionario, en aplicación primordialmente de las normas contables, será calificado y contabilizado como un activo intangible, puesto que el concesionario está asumiendo los riesgos inherentes a estos montos. De otro lado, respecto del valor asumido por el Estado, el concesionario deberá contabilizar esos ingresos como un activo financiero, en razón de que por esos montos no asume riesgo alguno de explotación y demanda, en consecuencia, las sumas recibidas por parte del Estado serán contabilizadas como una cuenta por cobrar. Esta clasificación se da en mérito a lo dispuesto en la norma contable denominada Interpretación a la CINIIF 12 Acuerdos de Concesión de Servicios.

Contablemente, la Interpretación CINIIF 12, estableció que las concesiones serían contabilizadas bajo los siguientes criterios, se reconocerá un activo intangible en la medida que el operador reciba un derecho a efectuar cargos a los usuarios del servicio público, este derecho no es incondicional a recibir efectivo, porque los ingresos generados están condicionados al grado de uso del servicio por los usuarios. Asimismo, se reconocerá contablemente un activo financiero en la medida que el concesionario adquiera un derecho incondicional a recibir una cantidad de efectivo de la concedente, mediante este derecho contractual la concedente le garantiza importes específicos de efectivo al operador. Por lo que el operador o concesionario deberá reconocer una cuenta por cobrar dentro de su contabilidad. 
Como podemos observar, esta norma contable ha otorgado un tratamiento especial a las concesiones en base a la contraprestación dada por el concedente al operador. Adicionalmente, la Interpretación CINIIF 12, reconoce dentro de su ámbito de aplicación al modelo contable de concesiones bifurcado o mixto, que según esta norma surge cuando se combinan ambas formas de contraprestación al operador señaladas anteriormente, por lo que, el concesionario deberá registrar en su información contable dos activos simultáneamente, el activo financiero y el activo intangible.

La regulación contenida en la Interpretación CINIIF 12 Acuerdos de Concesión de Servicios, ha permitido identificar los requisitos indispensables para que un operador o concesionario contabilice el bien sujeto a concesión como un activo intangible y/o un activo financiero. Desarrollaremos el alcance de dicha norma contable a mayor detalle más adelante.

Indudablemente esta remisión a las normas contables suscita una problemática en este artículo, lo que nos conlleva a cuestionarnos, si el artículo $22^{\circ}$ de la Ley de Concesiones que sólo limita su aplicación a los activos fijos e intangibles, ¿se podrá extender su aplicación a otro tipo de activos que surgen como consecuencia de la aplicación de las normas contables? Evidentemente, ello no es posible. Por lo tanto, un concesionario que reconozca contablemente otro tipo de activos por la naturaleza financiera de sus operaciones no podrá aplicar el beneficio establecido en el citado artículo $22^{\circ}$.

En ese sentido, debe quedar bastante claro que los beneficios fiscales establecidos en el artículo $22^{\circ}$ de la Ley de Concesiones están destinados únicamente a los activos fijos y activos intangibles mediante la depreciación o amortización, dejando fuera del ámbito de aplicación cualquier otro tipo de activo reconocido contablemente como es el caso de los activos financieros que surgen parcialmente en las concesiones bifurcadas o mixtas. En consecuencia, de originarse otros activos, para estos casos se aplicará lo regulado en el Texto Único de la Ley del Impuesto a la Renta aprobado mediante Decreto Supremo $N^{\circ}$ 179-2004-EF y normas modificatorias; y el correspondiente Reglamento de la Ley del Impuesto a la Renta aprobado mediante Decreto Supremo N 122-94-EF. 


\subsubsection{Aplicación parcial del artículo $22^{\circ}$ del Decreto Supremo $\mathrm{N}^{\circ}$ 059-96-PCM en las concesiones bifurcadas o mixtas}

En ese contexto, en las concesiones bifurcadas o mixtas, surgen conjuntamente dos tipos de activos clasificados contablemente como activo intangible y activo financiero, no pudiendo acogerse al beneficio establecido en el artículo $22^{\circ}$ de la Ley de Concesiones aquel valor que corresponda al activo financiero, sino únicamente el valor referido al activo intangible, en consecuencia, este procedimiento ocasiona desventajas y contingencias sustanciales no solo en materia fiscal sino también en materia económica porque la rentabilidad se verá afectada para aquellos concesionarios que celebraron un contrato de concesión de naturaleza bifurcada o mixta.

En particular, las cláusulas contractuales serán las herramientas principales para que el concesionario determine la naturaleza de clasificación de una concesión, por ello, es que, si mediante estas se cumple con el criterio de que los riesgos de explotación y/o demanda son compartidos por ambas partes contractuales, estaremos frente a una concesión bifurcada o mixta. Ahora bien, esta concesión deberá cumplir las condiciones de alcance señaladas en la norma contable de especialidad, para que sea aplicable la Interpretación CINIIF 12 Acuerdos de Concesión de Servicios, con la cual se podrá determinar cómo se ha de reconocer contablemente el bien cedido en concesión.

Es así que, en materia contable el concesionario reconocerá simultáneamente: i) un activo financiero, al cual le será de aplicación el régimen general contenido en la Ley del Impuesto a la Renta, y ii) un activo intangible que gozará del beneficio establecido en el artículo $22^{\circ}$ de la Ley de Concesiones porque encaja dentro de sus parámetros de alcance, por lo tanto, para este tipo de activos el concesionario podrá recuperar la inversión a través de la amortización durante la vida útil del bien materia de concesión con una tasa del $20 \%$ como máximo o mediante, la amortización íntegra en el periodo que reste para el vencimiento del plazo de la concesión, aplicando el método lineal.

Indiscutiblemente, el artículo $22^{\circ}$ de la norma especial de concesión, será aplicada parcialmente cuando estemos frente a un contrato de concesión bajo el modelo bifurcado o mixto, ello de conformidad con su naturaleza contable. Consecuentemente, el concesionario no podrá recuperar su inversión por el costo que representa todo el bien materia de concesión, sino únicamente por aquel valor que contablemente es aceptado como activo intangible. 
Hay que recordar que, una vez clasificada esta parte del bien materia de concesión como activo intangible, tendrá como tratamiento adicional lo señalado por la norma especializada en la materia, la Norma Internacional de Contabilidad NIC 38 Intangibles, que es aplicable y servirá de guía para efectuar la medición de los activos intangibles que posee el concesionario.

En concreto, el activo financiero no puede acogerse al artículo $22^{\circ}$ del Decreto Supremo $\mathrm{N}^{\circ}$ 059-96-PCM, entonces a este tipo de activos les será aplicable lo dispuesto en el régimen general del Impuesto a la Renta, mientras que por el activo intangible se puede aplicar el beneficio establecido en el artículo $22^{\circ}$ de la Ley de Concesiones y recuperar la inversión a través de la amortización. Al no haber conceptos claros en las leyes tributarias de los activos fijos y los activos intangibles, el Tribunal Fiscal en diferentes pronunciamientos ha interpretado que las normas contables son los referentes apropiados para ello. Por ejemplo, mediante la RTF Nro. 04995-2-2012 el Tribunal Fiscal señaló que:

De acuerdo con el artículo $223^{\circ}$ de la Ley General de Sociedades, Ley $\mathrm{N}^{\circ}$ 26887, los estados financieros se deben preparar y presentar de conformidad con las disposiciones legales sobre la materia y de acuerdo con los Principios de Contabilidad Generalmente Aceptados, y que mediante la Resolución $N^{\circ}$ 013-98-EF/93.01 del Consejo Normativo de Contabilidad se precisó que dichos principios, entre otros aplicados supletoriamente, son los contemplados en las Normas Internacionales de Contabilidad (NIC).

Asimismo, mediante la RTF № 07523-4-2017, el órgano resolutor estableció:

Que... de acuerdo con la Norma Internacional de Contabilidad - NIC 16, los inmuebles, maquinaria y equipo son activos tangibles que posee una empresa para ser utilizados en la producción o suministro de bienes y servicios, para ser alquilados a terceros o para propósitos administrativos, y que se espera usarlos durante más de un período.

Que... según el párrafo 8 de la Norma Internacional de Contabilidad NIC $^{\circ} 38$ Intangibles, éstos son activos identificables, de carácter no monetario y sin apariencia física, y de acuerdo al párrafo 21 un activo 
intangible se reconocerá si, y sólo si, es probable que los beneficios económicos futuros que se han atribuido al mismo fluyan a la entidad; y el costo del activo puede ser valorado de forma fiable.

El objetivo principal del artículo $22^{\circ}$ del Decreto Supremo $N^{\circ}$ 059-96-PCM, es recuperar la inversión que ha efectuado el operario a través de la amortización y depreciación en un plazo menor al establecido en la Ley del Impuesto a la Renta, sin embargo, como pudimos observar, solo será recuperable el valor que corresponda al activo intangible reconocido contablemente y no al activo financiero. Esta distorsión ocasionada por la falta de precisión en la norma tributaria y la consecuente remisión a las normas contables ocasiona que la rentabilidad del concesionario se vea afectada.

Consecuentemente, tenemos que la aplicación del artículo $22^{\circ}$ le brinda al concesionario mayor rentabilidad en el proyecto sujeto a concesión, dicho de otra manera, tiene un efecto positivo en la recuperación de la inversión del concesionario, pero este sólo puede ser aplicado de manera parcial cuando estamos frente a un contrato de concesión bifurcado o mixto, por la parte que corresponda reconocer contablemente un activo intangible, no pudiendo extender su aplicación al activo financiero.

Por lo tanto, de lo antes analizado, se observa que en las concesiones bifurcadas o mixtas el concesionario no podrá acogerse al tratamiento fiscal especial establecido en el artículo $22^{\circ}$ de la Ley de Concesiones, por la parte en que se reconozca una cuenta por cobrar al Estado (activo financiero), consecuentemente, el régimen tributario aplicable para ello será el régimen general, calificando como una prestación de servicios, ya sea como construcción o un servicio en general, al amparo de la Interpretación CINIIF 12 en el ámbito contable.

\subsubsection{Aplicación del régimen general del Impuesto a la Renta en las concesiones bifurcadas o mixtas}

Como se ha señalado las concesiones bifurcadas o mixtas que estén dentro del alcance de la Interpretación CINIIF 12, reconocerán contablemente un activo intangible y un activo financiero conjuntamente. El artículo $22^{\circ}$ del Decreto Supremo $N^{\circ}$ 059-96-PCM, será aplicable únicamente al valor reconocido como intangible, mientras que el activo 
financiero al estar fuera del ámbito de aplicación de este artículo le será aplicable la Ley del Impuesto a la Renta y su correspondiente Reglamento.

Cuando se determine que un bien materia de concesión califique como activo financiero, debido a la existencia del IMAG en el contrato de concesión bifurcada o mixta, el concesionario, contabilizará este activo financiero como una cuenta pendiente de cobro al Estado, por lo tanto, se reconocerá esta operación contra una cuenta contable de ingresos. Los activos financieros no gozarán de un mecanismo de deducción como el activo intangible mediante la amortización que otorga el artículo $22^{\circ}$, al no estar señalados en el citado artículo, por lo que, le será de aplicación lo dispuesto en el régimen general.

A manera de comentario, los activos financieros tienen su propio tratamiento contable regulado en las Normas Internacionales de Contabilidad NIC 32 y 39 y la Norma Internacional de Información Financiera NIIF 7. En consecuencia, la NIC 39 denominada Instrumentos Financieros, permite contabilizar el activo financiero, entre otros, como una cuenta por cobrar del Estado, que requiere de un interés calculado utilizando el método del interés efectivo. Por lo tanto, deberá reconocerse intereses adicionales en la etapa de explotación que serán calificados también como activos financieros y generan un incremento en los ingresos de la entidad, ellos en aplicación de las normas contables.

En esta línea, actualmente no es posible incluir al activo financiero dentro del alcance particular del artículo $22^{\circ}$ del Decreto Supremo $\mathrm{N}^{\circ}$ 059-96-PCM, porque este solo admite a los activos fijos y activos intangibles. De acuerdo con lo expresado, el concesionario deberá emplear lo determinado en las leyes generales como la Ley del Impuesto a la Renta, a aquellos activos calificados como financieros contablemente. Esta diferencia en el tratamiento que sufre una parte del bien materia de una concesión bifurcada o mixta por pactarse contractualmente el pago de ingresos por parte del Estado al concesionario mediante el IMAG, es el resultado de la redacción limitada del artículo $22^{\circ}$, que ha sido diseñado sin contemplar a otro tipo de concesiones, y más importante aún, estando redactado sobre la base de términos contables, no se actualiza considerando los cambios que las normas contables tienen periódicamente.

Si bien, este tratamiento tributario de los bienes materia de concesión en las concesiones bifurcadas o mixtas, se consideraría hoy en día como un procedimiento correcto (aplicación parcial del artículo $22^{\circ}$ en los intangibles y aplicación de la ley 
general en los activos financieros), no es el adecuado ni conveniente, puesto que la aplicación de la Ley del Impuesto a la Renta en el activo financiero tendrá un resultado negativo para la rentabilidad del concesionario y también tendrá efectos en el resultado tributario. Tampoco obedece al fin que se buscó cuando se dio esta norma, que era la de otorgarle al concesionario una recuperación conveniente por su inversión.

Por lo tanto, de lo antes analizado, se observa que en las concesiones bifurcadas o mixtas el concesionario no podrá acogerse al tratamiento fiscal especial establecido en el artículo $22^{\circ}$ de la Ley de Concesiones, por la parte en que se reconozca un activo financiero, ídem una cuenta por cobrar al Estado, consecuentemente, el régimen tributario aplicable para ello será el régimen general, calificando el activo financiero de acuerdo a las normas contables como un ingreso gravable del Impuesto a la Renta.

En conclusión, al carecer de una regulación tributaria explícita, son las normas contables las que regulan la calificación de los activos sujetos de concesión y, por tanto, en ocasiones estas normas distorsionan la forma de aplicar las leyes especiales fiscales sobre la materia, haciéndola incluso inaplicable. Asimismo, al no existir un pronunciamiento tributario claro respecto de cómo debería considerarse una concesión cuando surge contablemente un activo financiero como las concesiones bifurcadas o mixtas, los inversionistas no pueden bajo ninguna circunstancia gozar del beneficio establecido en el artículo $22^{\circ}$ de la Ley de Concesiones, por lo que, el concesionario debe limitarse al cumplimiento de las normas contables y aplicar sobre ellas las leyes tributarias con límites como el que se ha descrito.

\subsection{Remisión a las normas contables y la inseguridad jurídica para los concesionarios}

El autor Génova Galván señala lo siguiente:

Pues bien, con el específico significado de que la información contable se utiliza para percibir la renta de la sociedad y calificarla jurídicamente como hecho imponible del IS, podemos decir que en este impuesto se instrumentaliza la Contabilidad. Jurídicamente hemos de partir de la Contabilidad como una ciencia auxiliar que nos permita obtener "el reflejo 
de la verdadera situación patrimonial de la entidad" (como se citó en García Novoa, 1994, p. 31).

Según Labatut Serer, "la contabilidad sería así, al margen de cualquier pretendido prevalecimiento frente a la normativa tributaria" (como se citó en García Novoa, 1994, p. 33)., Ballesteros Pinto señala un instrumento de conocimiento, un signo de medición de la capacidad contributiva de la sociedad que, por estar tendencialmente destinada a dotar a la Administración de información sobre la capacidad tributaria de la actividad empresarial, es susceptible de "soluciones privativas" en el ámbito tributario. (como se citó en García Novoa, 1994, p. 33).

Actualmente, para que los concesionarios puedan aplicar el artículo $22^{\circ}$ de la Ley de Concesiones, deben remitirse obligatoriamente a la información financiera, información que es el resultado de la aplicación de las normas contables. Ello en mérito a que este artículo contiene definiciones y argumentos que no tienen mayor aclaración o precisión de carácter tributario, por ello, resulta obligatoria la remisión a estas normas contables. De lo expuesto en apartados anteriores, esta remisión está permitida, y respaldada por la Administración Tributaria y el Tribunal Fiscal, sin embargo, para el caso en concreto de las concesiones bifurcadas o mixtas, no se tiene pronunciamiento alguno de estos entes, que aclare si en estos casos especiales, es correcta la remisión a las normas contables para aplicar las leyes tributarias.

Cuando se está frente a un contrato de concesión tipificado como bifurcado o mixto, el concesionario tiene como respaldo de su tratamiento contable a la Interpretación CINIIF 12 Acuerdos de Concesión de Servicios, que entró en vigencia el 2006, y que es de uso obligatorio en el Perú a partir del año 2011, esta norma ha establecido las pautas necesarias para darle el tratamiento contable adecuado al bien materia de concesión, y ha delimitado que este bien debe ser reconocido en el caso de las concesiones bifurcadas o mixtas como un activo intangible y un activo financiero conjuntamente. Por lo tanto, a partir de este resultado contable se podría aplicar la normativa tributaria especial del artículo $22^{\circ}$ de la Ley de Concesiones, sin embargo, vemos que esta normativa no hace mención alguna al activo financiero y, por ende, resulta inaplicable para este componente contable de las concesiones bifurcadas o mixtas. 
En ese orden de ideas, son las normas contables las que actualmente regulan la calificación de los bienes sujetos de concesión y, por tanto, sumado a la falta de actualización de la norma especial tributaria que regule puntualmente su tratamiento, han ocasionado una distorsión en la forma de aplicar las leyes fiscales sobre la materia, haciéndola impracticable. Asimismo, al no existir un pronunciamiento claro respecto de cómo debería tratarse tributariamente las concesiones bifurcadas o mixtas, cuando surge contablemente un activo financiero, los inversionistas no pueden bajo ninguna circunstancia gozar del beneficio establecido en el artículo $22^{\circ}$, por lo que, el concesionario debe limitarse al cumplimiento de las normas contables y aplicar sobre ellas las leyes tributarias con límites como el que se ha descrito.

En las concesiones bifurcadas o mixtas, el concesionario no puede forzar el uso del artículo $22^{\circ}$ por la totalidad del valor del bien cedido en concesión sin considerar la clasificación que precisa la norma contable (activo intangible y activo financiero), debiendo aplicar las normas tributarias como corresponda, pese a que este procedimiento no obedezca a la verdadera finalidad que contiene la norma tributaria especial, que es la de otorgarle al concesionario la oportunidad de recuperar su inversión en un plazo menor mediante la amortización o depreciación, puesto que, al final de la concesión tendrá que devolverle el bien al Estado.

Como vemos la remisión a las normas contables no siempre mejora o despeja las dudas sobre los aspectos que no se incluyen en las leyes tributarias, con mayor razón porque, en ocasiones la Administración Tributaria o el Tribunal Fiscal hacen uso de esta remisión y no son consecuentes con los argumentos que exponen ni necesariamente coinciden en ellos, siendo que, en algunos casos pueden validar esta remisión a definiciones contables o pueden remitirse a definiciones jurídicas que otorgan otro enfoque a un caso en concreto (por mucho tiempo esta fue la problemática en el caso del concepto "devengado", que hoy ya tiene una regulación tributaria y ya no estará sujeto a interpretaciones de carácter contable o jurídico).

Actualmente, este tratamiento distorsionado del artículo $22^{\circ}$ del Decreto Supremo 059-96-PCM en las concesiones bifurcadas o mixtas no ha sido materia de análisis por parte de la Administración Tributaria ni por el Tribunal Fiscal, por lo que, no existen pronunciamientos objetivos al respecto, consecuentemente, los concesionarios aún no gozan de seguridad jurídica y están expuestos a que estas entidades tengan 
interpretaciones divergentes, lo que conlleva a que el concesionario continúe afrontando esta problemática de inseguridad jurídica no sólo por falta de precisión en las normas tributarias sino también por la remisión a las normas contables.

Caso aparte, mediante el Informe 038-2017/SUNAT la Administración Tributaria ha hecho referencia a la Interpretación CINIIF 12 Acuerdos de concesión de servicios, para atender una consulta relacionada al reconocimiento tributario de los ingresos en otro tipo de concesión. De ello podemos deducir que probablemente, en un eventual caso de análisis de la problemática de las concesiones bifurcadas o mixtas, la Administración Tributaria valide la remisión a esta interpretación contable porque en las normas tributarias de la especialidad no existe una aclaración explícita al respecto. Sin embargo, no se estaría analizando el problema de fondo, que es el perjuicio generado en la recuperación de la inversión del concesionario, al no aplicar el artículo $22^{\circ}$ a los activos financieros.

\subsubsection{Regulación contable de las concesiones bifurcadas o mixtas según la Interpretación CINIIF 12 Acuerdos de Concesión de Servicios}

En materia contable, con el fin de uniformizar la variada interpretación que utilizaban los concesionarios para contabilizar los bienes cedidos en concesión y darle el tratamiento financiero idóneo, en el año 2006 después de numerosos debates de más de cinco años en este proyecto, se publica la Interpretación CINIIF 12 Acuerdos de Concesión de Servicios, que fue emitida por el Comité de Interpretaciones de las Normas Internacionales de Información Financiera.

El autor Nalvarte Salvatierra (2011) manifiesta que:

En nuestro país, se ha publicado la Resolución N 044-2010-EF/94 del Consejo Normativo de Contabilidad, a través de la cual se oficializa la versión 2009 de las NIC, NIIF, CINIIF y SIC, así como sus modificaciones a mayo de 2010. En la referida resolución se señala expresamente que se incluye a la CINIIF 12, disponiéndose que todas las normas mencionadas entraran en vigencia el 1 de enero de 2011.

Cabe mencionar que el Consejo Normativo de Contabilidad es la instancia normativa del sector privado, conforme a lo dispuesto en el 
Artículo 10 de la Ley $N^{\circ} 28708$ - Ley General del Sistema Nacional de Contabilidad. (p. 90)

Esta norma contable que sirve de guía para los concesionarios estableció los parámetros y pautas de contabilización cuando se han celebrado contratos de concesión entre el inversionista y el Estado. Esta Interpretación CINIIF 12, resulta de aplicación para un variado conjunto de acuerdos de concesión de servicios celebrados entre el concedente, que viene a ser el Estado y, los operadores, quienes son los inversionistas privados denominados concesionarios. Entre este conjunto de concesiones reguladas por la Interpretación CINIIF 12, se encuentran las concesiones de tipo bifurcadas o mixtas.

Las características que deben tener los contratos de concesión para que les sea aplicable la citada Interpretación CINIIF 12 son las señaladas en su párrafo 3: i) el servicio público es asumido por el concesionario, ii) el concedente es un ente del sector público, iii) el operador es responsable de al menos una parte de la gestión de la infraestructura y de los servicios relacionados, iv) el contrato establece los precios iniciales que recaudará el operador y regula las revisiones de precios a lo largo del período del acuerdo de concesión de servicios y finalmente v) el operador está obligado a traspasar la infraestructura a la concedente a un determinado estado al final del plazo del acuerdo, a cambio de una pequeña contraprestación, o sin contraprestación alguna, con independencia de cuál fue la parte que la financió inicialmente.

Ahora bien, el librillo digital CINIIF 12 Acuerdos de concesión de servicios guía práctica de bolsillo, (2011) señala que, los principales requisitos que establece la Interpretación CINIIF 12 son los siguientes:

- Los activos que componen la infraestructura de la concesión no se deben reconocer como un inmovilizado material del concesionario, es decir no debe surgir un activo fijo, porque no hay una transferencia de propiedad.

- Los ingresos que fluctúan durante la fase de explotación se reconocen y se valoran de conformidad con la NIC 11 Contratos de Construcción y/o de conformidad con la NIC 18 Ingresos de Actividades Ordinarias.

- Los costos por los intereses incurridos por el concesionario que sean imputables al acuerdo de concesión se reconocen como un gasto del periodo en que se devengan. 
- $\quad$ La NIC 39 Instrumentos Financieros y la NIIF 9 Instrumentos Financieros son aplicables al activo financiero reconocido con arreglo a la Interpretación CINIIF 12. De conformidad con la NIC 39, el activo financiero, se medirá posteriormente bien al coste amortizado o a valor razonable.

- La contraprestación recibida por el concesionario se reconoce a valor razonable, la contraprestación puede dar lugar al reconocimiento de un activo financiero o un activo intangible o ambos conjuntamente.

Ahora bien, la Interpretación CINIIF 12 se aplica a los acuerdos de concesión de servicios públicos a un operador privado, si cumple simultáneamente los siguientes requisitos establecidos en el párrafo 5 de la citada norma: a) la concedente controla o regula que servicios debe proporcionar el operador con la infraestructura, a quién debe proporcionarlos y a qué precio; y b) la concedente controla a través de la propiedad, del derecho de uso o de otra manera, cualquier participación residual significativa en la infraestructura al final del plazo del acuerdo.

Por su parte, para el propósito de determinar si la concedente controla el precio pactado en el contrato de concesión, no es imprescindible que el Estado, quien tiene la figura de concedente, tenga el control total para establecer el precio, es decir que, sólo será suficiente que el precio pactado contractualmente esté ajustado ya sea por el Estado, el contrato $\mathrm{u}$ otro mecanismo que lo restrinja. Como señalamos en reiteradas oportunidades, el tratamiento contable y financiero de un acuerdo de concesión de servicios estará basado en los términos y condiciones específicas del contrato de concesión.

A mayor abundamiento, según establece el párrafo 18 de la Interpretación CINIIF 12, si se paga al operador por los servicios de construcción, en parte mediante un activo financiero y en parte mediante un activo intangible, es necesario que cada componente de la contraprestación del operador se contabilice por separado. La contraprestación recibida o a recibir por ambos componentes deberá ser inicialmente reconocida por el valor razonable de la contraprestación recibida o por recibir.

En el párrafo FC 53 Fundamentos de las Conclusiones, desarrolladas en la Interpretación CINIIF 12 Acuerdos de Concesión de Servicios, se establece lo siguiente respecto del modelo contable de las concesiones bifurcadas o mixtas: 
El [Consejo de Normas Internacionales de Contabilidad] CINIIF concluyó que, si se paga al operador por sus servicios de construcción, en parte mediante un activo financiero y en parte mediante un activo intangible, es necesario que cada componente de la contraprestación del operador sea contabilizado por separado. El [Consejo de Normas Internacionales de Contabilidad] CINIIF incluyó el requerimiento de contabilizar por separado cada componente (algunas veces conocido como un acuerdo bifurcado) de la contraprestación del operador, en respuesta a una preocupación surgida en el proyecto de Interpretaciones. La preocupación era que, en algunos acuerdos, ambas partes del contrato comparten el riesgo (riesgo de demanda) de que los flujos de efectivo generados por los usuarios del servicio público no sean suficientes para recuperar la inversión del operador. Para lograr el reparto deseado de riesgo, normalmente las partes conciertan acuerdos según los cuales la concedente paga al operador por sus servicios, en parte mediante un activo financiero y en parte mediante la concesión de un derecho a cobrar a los usuarios del servicio público (un activo intangible). El [Consejo de Normas Internacionales de Contabilidad] CINIIF concluyó que en esas circunstancias sería necesario dividir la contraprestación del operador en un componente de activo financiero para cualquier importe garantizado de efectivo $\mathrm{u}$ otro activo financiero y un activo intangible por el resto.

Como se puede apreciar, uno de los motivos fundamentales para darle un tratamiento contable a las concesiones bajo un modelo contable de bifurcado, fue el riesgo de demanda. Nótese que para efectos financieros se tomó en cuenta este importante riesgo involucrado, puesto que los operadores deseaban conocer cómo debía contabilizarse las concesiones en las cuales el riesgo de demanda es asumido de forma simultánea, tanto por el concesionario como por el Estado. Por lo tanto, en un modelo contable bifurcado o mixto, el riesgo de demanda es compartido por ambas partes contractuales, de ahí que el enfoque contable que se le dio permitió que ambas partes puedan ser contabilizadas y registradas por su valor correspondiente como activo intangible y activo financiero. 
Por lo tanto, en un modelo de contrato de concesión de tipo bifurcado o mixto, cuando un concesionario recibe del Estado una contraprestación de un activo financiero, representado por el monto que el concedente se comprometió a otorgar y, también recibe un activo intangible, por el derecho de uso o explotación, resulta imprescindible que se contabilice por separado cada uno de estos activos, para estos efectos el concesionario debe evaluar el tratamiento económico de la contraprestación. Esta diferenciación en el registro contable se debe producir en la fecha de reconocimiento inicial.

$\mathrm{Al}$ respecto, el librillo digital CINIIF 12 Acuerdos de concesión de servicios guía práctica de bolsillo, (2011), señala que:

Se adopta un "enfoque residual" para calcular un valor para ambos componentes. En la medida en que el operador adquiere un derecho contractual a recibir efectivo de la concedente, o de una entidad bajo la supervisión de ésta, se reconoce un activo financiero. En caso de que el valor razonable de los servicios de construcción prestados exceda del valor razonable del activo financiero reconocido, la diferencia se reconocerá como activo intangible. (p. 41).

En definitiva, las concesiones que estén dentro del alcance de la Interpretación CINIIF 12 Acuerdos de Concesión de Servicios, serán clasificadas contablemente como activo intangible y activo financiero, o ambas figuras en simultáneo como sucede en las concesiones bifurcadas o mixtas, materia del presente trabajo de investigación. Como vimos, este tratamiento contable tiene por efecto que la aplicación del beneficio tributario del artículo $22^{\circ}$ del Decreto Supremo $\mathrm{N}^{\circ}$ 059-96-PCM, tenga alcance únicamente al activo intangible, mientras que por el activo financiero se aplicarán las normas generales establecidas en la Ley del Impuesto a la Renta y su correspondiente Reglamento.

\subsubsection{Implicancias tributarias por el reconocimiento de un activo financiero y un activo intangible en aplicación de la Interpretación CINIIF 12}

La remisión a las normas contables en ocasiones puede generar una distorsión en el tratamiento tributario de ciertos casos particulares. Tal es el caso, de la aplicación de la Interpretación CINIIF 12 Acuerdos de Concesión de Servicios, la cual nos aleja parcialmente del tratamiento fiscal especial contenido en el artículo $22^{\circ}$ de la Ley de 
Concesiones. La norma contable ha dejado al activo financiero, producto de una concesión bifurcada o mixta, fuera del ámbito de aplicación de un beneficio tributario para el concesionario.

Con la finalidad de ampliar el panorama respecto del perjuicio ocasionado por la limitación establecida en el artículo $22^{\circ}$ del Decreto Supremo $N^{\circ}$ 059-96-PCM, se desarrollará un caso práctico referido a la aplicación de la Interpretación CINIIF 12 Acuerdos de Concesión de Servicios, y la consecuente distorsión generada para efectos tributarios. Ello, en mérito al reconocimiento conjunto de un activo intangible y un activo financiero en las concesiones bifurcadas o mixtas. Basándonos en un caso del librillo digital CINIIF 12 Acuerdos de concesión de servicios guía práctica de bolsillo, (2011) se tiene lo siguiente:

Un inversionista celebra un contrato de concesión con el Estado Peruano, para que brinde sus servicios de construcción y de operación de una carretera. Para tal efecto, se tiene los siguientes datos: Los costos de construcción ascienden a 1,000 millones de soles. Respecto de las retribuciones a percibir se ha establecido en el contrato, una estimación de ingresos total de 3,000 millones de soles a lo largo del periodo que dure el contrato de concesión.

El concedente ha garantizado mediante el IMAG un ingreso de 1,200 millones de soles. Por su parte, los ingresos financieros (intereses) que deben ser reconocidos según lo establece la NIC 39, ascienden a 120 millones de soles durante el periodo de vigencia del contrato de concesión. Finalmente, se determinó que el valor razonable de los servicios de construcción es de 2,500 millones de soles.

Bajo el tratamiento del enfoque residual establecido por la Interpretación CINIIF 12 se tiene el siguiente resultado:

Tabla 3.1

Cálculo del valor del activo financiero

\begin{tabular}{|l|r|}
\hline Conceptos & Millones S/ \\
\hline Ingresos garantizados por la concedente & 1,200 \\
\hline Intereses (aplicación NIC 39) & 120 \\
\hline Valor contable del Activo Financiero & $\mathbf{1 , 3 2 0}$ \\
\hline
\end{tabular}

Fuente: Elaboración propia 
Tabla 3.2

Cálculo del valor del activo intangible

\begin{tabular}{|l|r|}
\hline Conceptos & Millones S/ \\
\hline Ingresos a valor razonable & 2,500 \\
\hline Activo Financiero & $(1,200)$ \\
\hline Valor contable del Activo Intangible & $\mathbf{1 , 3 0 0}$ \\
\hline
\end{tabular}

Fuente: Elaboración propia

Tabla 3.3

Registro contable durante la etapa de construcción:

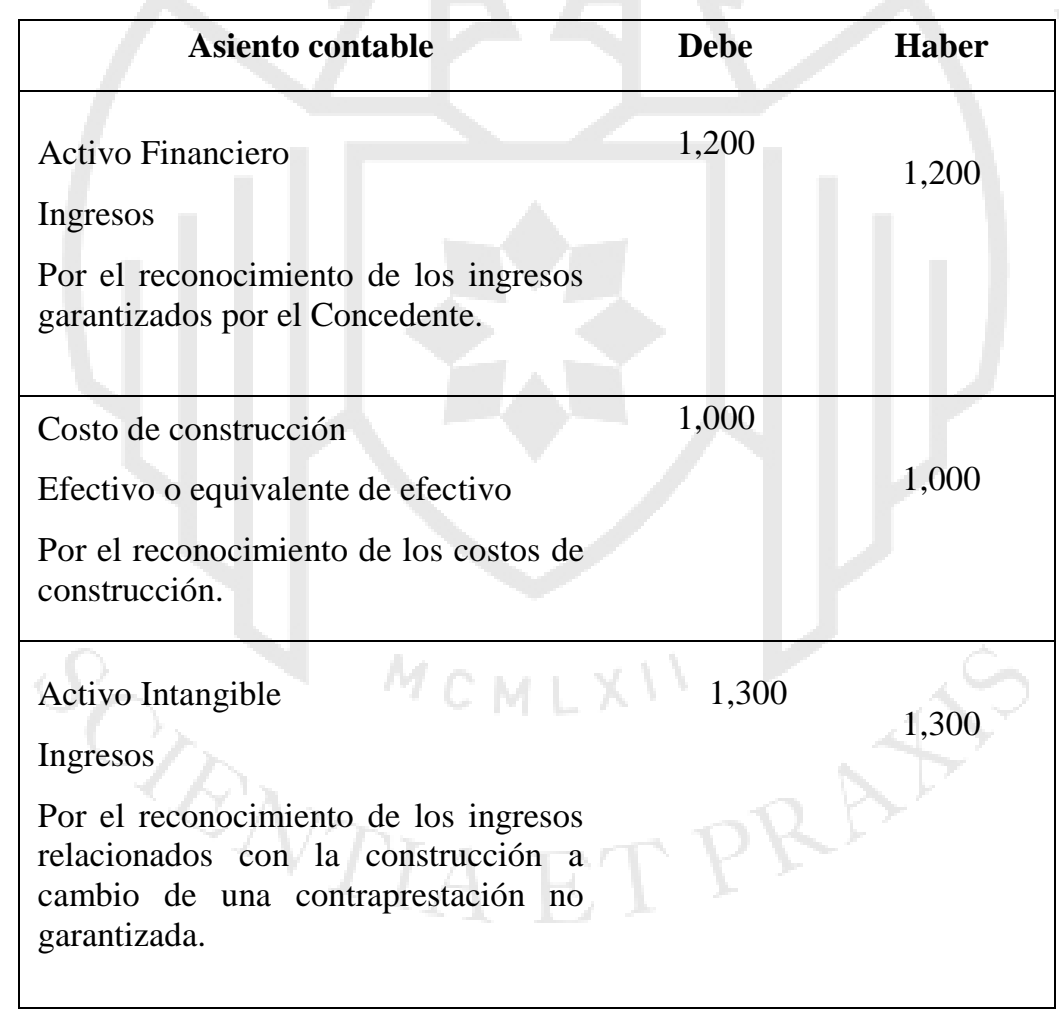

Fuente: Librillo digital CINIIF 12 Acuerdos de concesión de servicios guía práctica de bolsillo, (2011)

Elaboración propia

\section{Table 3.4}

Registro contable durante la etapa de explotación: 


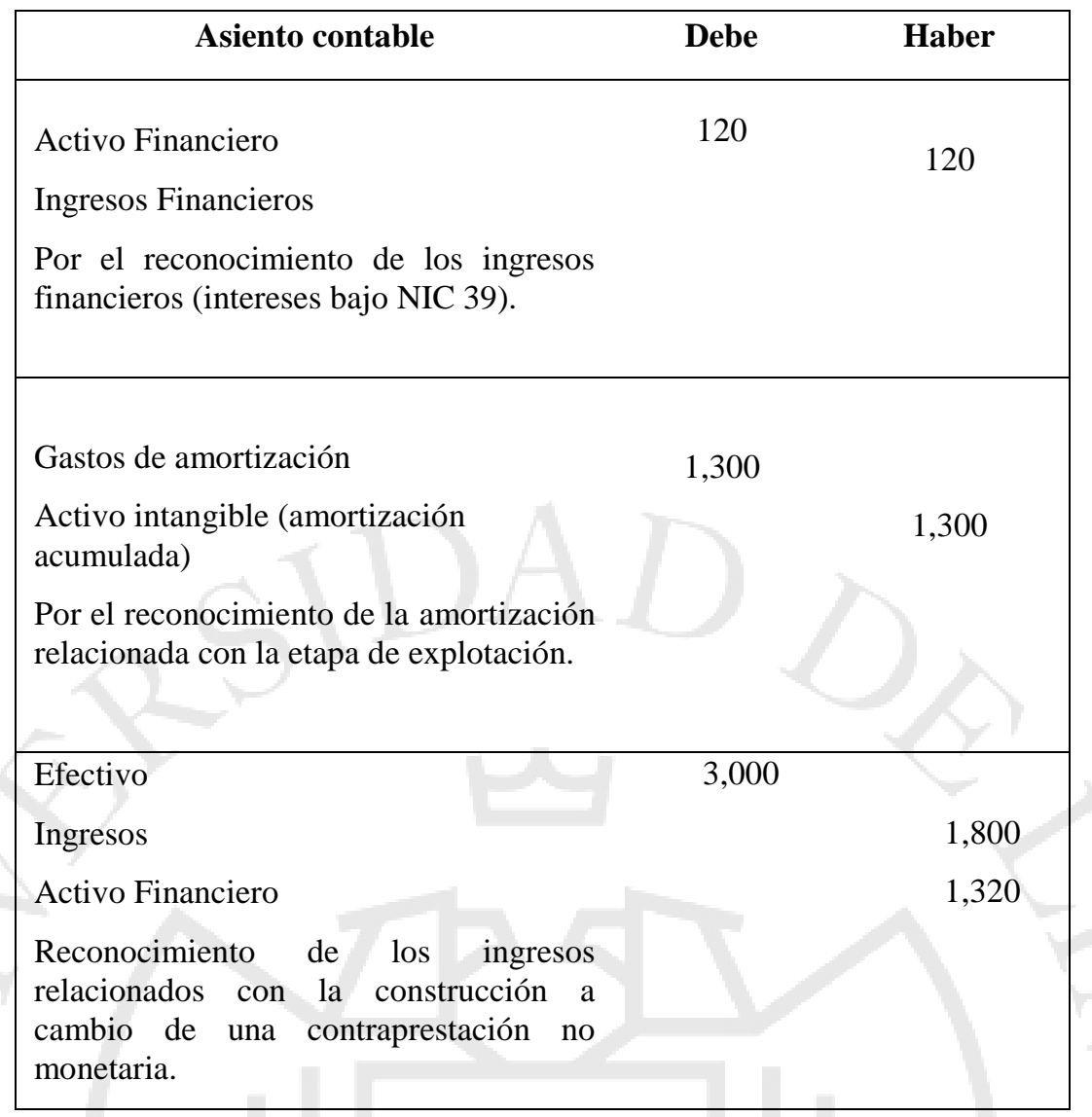

Fuente: Librillo digital CINIIF 12 Acuerdos de concesión de servicios guía práctica de bolsillo, (2011)

Elaboración propia

Ingresos totales registrados a lo largo de la vigencia del contrato de concesión ascienden a: S/ 4,420 millones y los ingresos efectivamente cobrados ascienden a S/ 3,120 millones. Por ende, en aplicación del tratamiento tributario limitado establecido en el artículo $22^{\circ}$ de la Ley de Concesiones se tiene lo siguiente:

Tabla 3.5

Resumen de Ingresos y Gastos

\begin{tabular}{|l|r|}
\hline Ingresos derivados del activo financiero & 1,320 \\
\hline Ingresos derivados del activo intangible & 1,300 \\
\hline Ingresos efectivos en la etapa de explotación & 1,800 \\
\hline Ingresos gravados totales & $\mathbf{4 , 4 2 0}$ \\
\hline (-) Gastos deducibles (amortización art. 22 $^{\circ}$ ) & $(1,300)$ \\
\hline Ingresos Netos (Base Imponible Impuesto a la Renta) & $\mathbf{3 , 1 2 0}$ \\
\hline Impuesto a la Renta (29.5\%) & 920 \\
\hline
\end{tabular}

Fuente: Elaboración propia 
En consecuencia, tenemos que en las concesiones bifurcadas o mixtas contablemente se reconocerá un activo financiero y un activo intangible al bien materia de concesión. El artículo $22^{\circ}$ del Decreto Supremo $N^{\circ}$ 059-96-PCM tiene alcance únicamente a la parte del activo intangible, por lo que el concesionario amortizará este activo durante un plazo distinto al de las leyes generales. La remisión a la Interpretación CINIIF 12 ha dejado fuera del ámbito de aplicación de este artículo $22^{\circ}$ al activo financiero reconocido contablemente, por lo tanto, para este valor será de aplicación la Ley del Impuesto a la Renta, reconociéndose un ingreso gravable. Por ende, este resultado es el impacto negativo de la remisión a normas contables en el caso de las concesiones bifurcadas o mixtas para la recuperación de la inversión.

\section{CAPÍTULO III: NUESTRA PROPUESTA NORMATIVA}

\subsection{Alternativas de solución}

Como pudimos observar y analizar en todo el desarrollo del presente trabajo de investigación, el artículo $22^{\circ}$ de la Ley de Concesiones, que aún se encuentra en vigencia, tiene un límite en su ámbito de aplicación para aquellas concesiones que contablemente califican como bifurcadas o mixtas de acuerdo a lo establecido en la Interpretación CINIIF 12 Acuerdos de Concesión de Servicios. Para gozar totalmente del beneficio establecido en el controvertido artículo, que otorga un sistema de recuperación de la inversión al concesionario mediante la depreciación o amortización, es necesario e imprescindible que el bien transferido califique como un activo fijo o un activo intangible.

Ahora bien, en caso de haberse celebrado un contrato de concesión clasificada como bifurcada o mixta, en la cual participan tanto el Estado como el concesionario y comparten conjuntamente el riesgo de demanda y/o explotación, se reconocerá contablemente, bajo lo establecido en la Interpretación CINIIF 12 Acuerdos de Concesión de Servicios, los siguientes activos conjuntamente:

i. Activo Financiero, bajo esta premisa, se dará cabida a una cuenta por cobrar al Estado por la parte en que este último le garantiza al 
concesionario un monto fijo de retribución mediante la figura del Ingreso Mínimo Anual Garantizado (IMAG); y, por otra parte,

ii. Activo Intangible, en mérito a que, si durante la explotación o usufructo del bien y/o servicio otorgado en concesión se generasen ingresos superiores al IMAG, será el concesionario quien asumirá el riesgo de explotación o demanda por esta parte de los ingresos.

$\mathrm{Al}$ respecto, será en base a este tratamiento contable de las concesiones bifurcadas o mixtas, que se definirá la aplicación tributaria del artículo $22^{\circ}$ en cuestión. Siendo así, nos encontramos ante una situación en la que no resulta de aplicación este artículo, puesto que el concesionario ha registrado como un activo financiero los ingresos que el Estado se obliga a retribuirle obligatoriamente bajo una cláusula económico-financiera del contrato, teniendo alcance únicamente al activo intangible. En otras palabras, en tanto se celebre un contrato de concesión clasificado como bifurcado o mixto, el concesionario no recuperará la inversión efectuada mediante la amortización a una tasa del $20 \%$ de forma lineal como establece el artículo $22^{\circ}$ por los ingresos que el Estado le garantizó retribuirle, es más, ni siquiera la recuperará bajo ningún mecanismo.

Entonces, en este supuesto de inaplicabilidad, cuando contablemente el concesionario ha registrado un activo financiero contra una cuenta de ingresos, el concesionario tributará bajo el enfoque de las leyes fiscales generales, habida cuenta le será de aplicación lo establecido en la Ley del Impuesto a la Renta y su correspondiente Reglamento. Por ende, al calificar como una cuenta por cobrar la retribución de demanda asumida y garantizada por el Estado en favor del concesionario, este último no podrá amortizarla bajo lo establecido, no sólo en la Ley de Concesiones, sino adicionalmente en la Ley del Impuesto a la Renta y su Reglamento. Ello básicamente porque este registro contable no tiene una naturaleza financiera de activo intangible, por el contrario, la Interpretación CINIIF 12 le atribuye un tratamiento posterior a este activo financiero, que está establecido en la Norma Internacional de Contabilidad 32 Instrumentos Financieros.

Por ende, el concesionario, únicamente podrá aplicar la Ley del Impuesto a la Renta y sus correspondientes modificaciones y actualizaciones normativas, y reconocerá tributariamente esta ganancia garantizada como un ingreso ordinario gravado con el correspondiente Impuesto a la Renta, sujeto a las tasas impositivas de aplicación que 
estén vigentes o se hayan acordado mediante un contrato de estabilidad tributaria, no pudiendo deducir ningún tipo de amortización.

De estas afirmaciones, se deduce que los párrafos 2,3 y 4 del artículo $22^{\circ}$ de la Ley de Concesiones no incluyen dentro de su ámbito aplicativo a aquellas concesiones que den lugar a un activo distinto de los activos fijos o activos intangibles, como es el caso del activo financiero, que es el resultado del tratamiento contable de las concesiones bifurcadas o mixtas, dando cabida a que se apliquen las normas generales fiscales en sustitución a este vacío normativo, lo que conlleva lamentablemente a que el concesionario no tenga ningún mecanismo de recuperación de la inversión efectuada por el activo financiero, y por el contrario sus ingresos sean gravados con la tasa que corresponda.

Como se aprecia, esta distorsión, es generada debido a la falta de precisión en la aplicación del artículo $22^{\circ}$ de la Ley de Concesiones, que permita ampliar su destino a otro tipo de activos, puesto que no resulta idóneo que solo condicione su tratamiento a dos conceptos meramente contables y no ampliatorios como son la amortización y la depreciación. Consideramos que el tratamiento contable no siempre es idóneo para la aplicación de las normas tributarias, puesto que las desnaturaliza en el tiempo. Recordemos que las normas contables se encuentran normalmente en actualizaciones y modificaciones periódicas buscando uniformizar criterios de la diversa casuística que surgen en el mundo contable, y buscando ante todo la eficacia en la información a presentarse financieramente. Por ende, resulta no sólo ideal sino imprescindible contar con normas tributarias claras y que abarquen la mayor cantidad posible de casos que puedan sufrir algún desvarío.

Las concesiones al representar una de las figuras económicas más importantes que realiza el Gobierno Peruano para el desarrollo del país, necesita actualizar sus normas fiscales involucradas al respecto, normas que han quedado obsoletas con el paso del tiempo, y buscando no sólo un beneficio para el Estado sino también un beneficio homogéneo y atractivo para los concesionarios. Hay que aclarar que remitirnos a normas de carácter contable y financiero no resulta un mecanismo ineficiente, lo que resulta así es que, ante la actualización constante de estas normas, las leyes tributarias no vayan de la mano con estos cambios que puedan afectar el tratamiento especial que se otorga a determinados sectores. 
En ese orden de ideas, desarrollaremos dos propuestas de solución con la finalidad de contrarrestar la distorsión fiscal generada sobre los bienes comprendidos en las concesiones de tipo bifurcadas o mixtas. Estas propuestas de solución que pasaremos a exponer y sustentar son: i) modificación normativa del artículo $22^{\circ}$ y, ii) introducción de un gasto deducible. De estas propuestas nos inclinamos principalmente a favor de la primera, mediante la cual proponemos una modificación normativa del mismo artículo $22^{\circ}$ de la Ley de Concesiones que permita una reclasificación de un activo financiero a un activo intangible para efectos netamente tributarios.

\subsubsection{Modificación normativa}

Para desarrollar la presente propuesta de solución mediante una modificación normativa del artículo $22^{\circ}$ del Decreto Supremo $N^{\circ}$ 059-96-PCM, previamente es necesario recordar que algo semejante ocurrió en el año 1998. Cuando se estableció la Ley de Concesiones, y se puntualizó el tratamiento fiscal mediante sus artículos $21^{\circ}$ y $22^{\circ}$, este último regulaba únicamente el tratamiento tributario de los bienes materia de concesión que calificaran como activos fijos, ello porque este párrafo establecía un mecanismo de recuperación de la inversión a través de la depreciación de un activo fijo. Dicho de otra manera, mediante el segundo y tercer párrafos del artículo $22^{\circ}$, se estableció el tratamiento tributario especial de los bienes y/o servicios otorgados en concesión, con el fin de que el concesionario pueda recuperar su inversión a través de la depreciación lineal en un 20\% anual como máximo. Como resultado la citada norma era más limitante.

Posiblemente este precepto se dio considerando que en el Perú se firmaba contratos de concesión bajo el esquema BOOT (Build, Own, Operate, Transfer), es decir para aquellas concesiones mediante las cuales el concesionario adquiría el derecho de propiedad durante un plazo determinado, dando nacimiento al registro contable de un activo fijo. Razón por la cual, la norma tenía alcance para aquellas concesiones en las que surgiera únicamente un activo fijo y el derecho de propiedad la tenía el concesionario.

En contraste con lo anterior, con el tiempo se presentaron otras figuras contractuales de las concesiones a celebrarse por el Estado Peruano, ello evidenció que no solo podía surgir un activo fijo bajo el modelo BOOT, sino que adicionalmente, se daba lugar a modelos concesionarios mediante los cuales el Estado cedía a un tercero 
privado ciertos derechos y obligaciones sin desvincularse de la propiedad de la infraestructura o servicio. Conviene subrayar, que este tercero adquiría un derecho de explotación, uso o usufructo sobre dicho bien y/o servicio público, dando lugar a un activo intangible susceptible de amortización. Como resultado, se propuso la modificación del artículo $22^{\circ}$ de la Ley de Concesiones, con la finalidad de ampliar su ámbito de aplicación y considerar dentro de este, a aquellas concesiones celebradas bajo el esquema BOT (Build, Operate, Transfer), modelo concesionario en el que el Estado aún mantiene el derecho de propiedad sobre la infraestructura y/o servicio público y únicamente cede el derecho de explotación al concesionario.

En razón a estas consideraciones, es que mediante la Ley $\mathrm{N}^{\circ} 27156$, publicada en fecha 17/07/1999 se incorpora el cuarto párrafo del artículo $22^{\circ}$ de la Ley de Concesiones, ampliando el ámbito aplicativo a aquellas concesiones que dan lugar al nacimiento de los activos intangibles de duración limitada derivados del derecho de uso sobre los activos transferidos al Estado. Al respecto, en el Capítulo I del presente trabajo de investigación, se citó el motivo de sustento expuesto por el congresista Luis Chang Ching, en el pleno del Congreso de la República de fecha julio de 1999, examinaremos brevemente ahora sus argumentos adicionales para esta modificación, el congresista expuso lo siguiente:

El caso es que el 16 de junio la Comisión de Economía, en una reunión de trabajo, recibió la visita del presidente de la Corporación Peruana de Aviación Comercial, Corpac, y se señaló en aquella oportunidad que el tipo de concesión, por ejemplo, del aeropuerto Jorge Chávez sería con esta nueva modalidad que estamos incluyendo dentro de la norma. Por ejemplo, sería una en la cual se construyen las nuevas instalaciones del aeropuerto, se operan y, después de terminada la -diríamos- concesión, se mantiene el tema de las transferencias; pero la propiedad del bien sigue siendo del Estado. El Estado en ningún momento cede la propiedad a quien pueda ganar la concesión.

De esta forma, queda claro que, por ejemplo, en el caso de Enafer, en el momento en que pueda ser dada en concesión, las vías, los durmientes del ferrocarril, continúan siendo de propiedad del Estado. Y, por lo tanto, en el tema de aeropuertos, de puertos, de ferrocarriles y otros, es el Estado el que mantiene permanentemente la propiedad. 
Por esa razón, la modificación del artículo $22^{\circ}$ y el artículo $21^{\circ}$ del Texto Único Ordenado de la Ley de Concesiones tiene que incorporar esta nueva modalidad para que pueda realizarse adecuadamente todo el proceso.

Indudablemente lo expuesto por el congresista Chang, deja claro que el nuevo modelo concesionario a tomar en cuenta es el clasificado como BOT, que por sus siglas en inglés significa, construir, operar y transferir el bien concesionado, términos mencionados en los ejemplos expuestos por el parlamentario, asimismo, hace una referencia importante al motivo por el cual este modelo concesionario debía recibir el tratamiento de un activo intangible, este motivo es la "transferencia del derecho de propiedad" del bien materia de concesión. Por lo que, de no darse esta transferencia, el derecho de uso de una concesión puede ser tratado como activo intangible.

En consecuencia, la recuperación de la inversión, a partir de esta modificación se efectuaría, adicionalmente mediante la amortización durante el mismo plazo que se aplicaría en el caso de las depreciaciones, a una tasa del $20 \%$ anual de forma lineal como máximo.

Ahora bien, a casi 20 años posteriores de la regulación de esta norma, no cabe duda de que, durante el proceso de aplicación de la legislación, salen a la luz casos particulares como el de las concesiones bifurcadas o mixtas que dan cuenta que esta norma es insuficiente y que hoy en día es inaplicable a ciertos tipos de concesiones, al no comprender la totalidad de casos reales que se vienen presentando, dicho esto, resulta no solo necesario sino imprescindible actualizar y modificar este artículo, para regularizar la controversia fiscal generada por las normas contables.

Ciertamente las normas que emiten los legisladores no pueden ser muy específicas para cada caso en concreto, puesto que el legislador lo que busca a través de su emisión es que abarquen lo más posible toda la casuística que pueda generarse, y así fue como en aquel entonces se realizó la última modificación a tan importante dispositivo legal, a raíz de la aparición de una nueva modalidad concesionaria en nuestro país. Sin embargo, no se trata tan solo de quedarnos con una norma establecida únicamente para dos modelos concesionarios, por ello, resulta necesario que se amplíe el ámbito de aplicación a otro tipo de concesiones como las bifurcadas o mixtas. 
Si bien es cierto, nuestro ordenamiento tributario es aplicable a los resultados contables, todo esto parece confirmar que, para el ámbito tributario, no siempre es conveniente remitirnos a normas supletorias que nos alejan del tratamiento fiscal que corresponde aplicar. Considerando que si bien a medida que pasa el tiempo las normas contables han uniformizado el tratamiento de las concesiones a nivel financiero, debemos tener presente que están en constante cambio, mientras que las normas tributarias que les son aplicables no siempre van de la mano con ellas en cuanto a su actualización, dejando de lado casos como el que hemos desarrollado en el presente trabajo y, por lo tanto, generando inseguridad jurídica en su tratamiento.

En el caso que algún concesionario privado haya aplicado el artículo $22^{\circ}$ en las concesiones de tipo bifurcadas o mixtas, sin hacer una distinción de los dos activos que se generan (intangible y financiero), y considerando la totalidad como un activo intangible, representará una contingencia económica notable en materia fiscal, puesto que la Administración Tributaria podrá interpretar esta aplicación como indebida por los motivos expuestos, imputándole al concesionario deudas superiores entre omisiones y multas, puesto que los valores económicos tratados en las concesiones son sustanciales; el concesionario no tendrá un sustento legal que justifique su posición, y con mayor razón, porque actualmente no se tiene ningún pronunciamiento por parte de la Administración Tributaria ni del Tribunal Fiscal al respecto.

Por ende, la modificación normativa que se propone y que a nuestro juicio es la mejor alternativa de solución al problema que presentan las concesiones bifurcadas o mixtas, es que para efectos de la aplicación del tratamiento tributario especial contenido en el artículo $22^{\circ}$ de la Ley de Concesiones, se debe reclasificar la parte del activo calificado como financiero por la Interpretación CINIIF 12 Acuerdos de Concesión de Servicios, a un activo intangible, en tanto el Estado no transfiere el derecho de propiedad del bien concesionado al concesionario, y este último solo asumió un derecho de uso del bien.

Con esta propuesta, se estaría precisando en el artículo $22^{\circ}$ que, para efectos de su aplicación se debe considerar que todo bien transferido al concesionario que implique un derecho de uso de duración limitada, en tanto el Estado no le haya trasladado el derecho de propiedad de este bien materia de concesión, debe ser tratado como un activo intangible, siéndole de aplicación lo señalado en el citado artículo. Bajo esta premisa, se 
entendería que, no obstante, el bien materia de una concesión bifurcada o mixta califique, acorde con las normas contables, como activo intangible y activo financiero, tributariamente todo el valor será tratado como un activo intangible susceptible de amortización. De este modo, el activo financiero que se dio contablemente en estas concesiones retornará bajo este supuesto al tratamiento fiscal contenido en dicho artículo.

Se considera que esta es la mejor alternativa de solución por representar un camino más viable de recuperación de la inversión. No se trataría de introducir nuevos conceptos que puedan generar mayor confusión o controversia en el citado artículo, es decir, no se está proponiendo la inclusión del concepto de activo financiero (término contable) sino se estaría efectuando una aclaración de que, en caso se generen contablemente activos distintos al fijo o intangible, para efectos de la norma en cuestión, serán tratados como activos intangibles en tanto el concesionario tenga un derecho de uso sobre los bienes otorgados en concesión. Esta aclaración en el artículo $22^{\circ}$ no conlleva a que se deban plantear parámetros numéricos en la citada norma, como son los porcentajes adicionales o nuevos, fuera de los ya establecidos, ni introducir un mecanismo de recuperación exclusivo para el activo financiero, puesto que esos procedimientos resultan más complejos y dificultosos. Solo se está precisando que, para efectos de la norma, sin importar la calificación contable, deba tratarse al bien materia de concesión bifurcada o mixta como un activo intangible.

Se debe agregar que, esta propuesta de reclasificación obedece a que, al no existir un mecanismo de recuperación como la depreciación y amortización para un activo financiero, no es posible establecer un mecanismo de recuperación exclusivo de este concepto y de serlo, su elaboración resultaría compleja. Con mayor razón porque el activo financiero es un término de naturaleza contable, que está sujeto a variaciones por cambios en las propias normas contables y financieras. Por ello, no se propone una definición tributaria de activo financiero, porque puede generar controversia, sino únicamente se propone una reclasificación.

Avanzando con este razonamiento de modificación normativa, el autor Nalvarte Salvatierra (2011) señala que:

Dentro de este contexto (reconocimiento de la IFRIC 12 en la Unión Europea, en Argentina y en nuestro país, solo por citar algunos ejemplos) resulta imperativo, a nuestro parecer, modificar el artículo $22^{\circ}$ del TUO 
de Concesiones, de manera tal que se señale, claramente, cual es el tratamiento contable aplicable a las inversiones efectuadas en el marco de una concesión, dependiendo de las características de la concesión en particular y de acuerdo con los criterios plasmados en la IFRIC 12.

Esto resulta importante porque, tal como se ha demostrado en el presente documento, la forma de registrar contablemente las inversiones efectuadas en el marco de una concesión tiene repercusiones directas en la TIR y el VAN del proyecto. (p. 90)

$\mathrm{Al}$ respecto, coincidimos con el autor cuando manifiesta que no cabe duda de que se debe modificar el controvertido artículo, puesto que la forma de registrar contablemente las inversiones tiene consecuencias en los indicadores de rentabilidad del concesionario, como se pudo evidenciar. Ante la limitación normativa tributaria y las consecuencias económicas que afronta el concesionario, es necesaria la modificación de este artículo.

Por el contrario, no coincidimos con la idea del autor cuando refiere que, mediante la modificación del artículo $22^{\circ}$, se deba señalar claramente el tratamiento contable aplicable a las inversiones. En efecto, la finalidad de una norma tributaria no es definir el tratamiento contable de un hecho económico, este aspecto de contabilización es regulado por sus propias reglas sobre la materia como las Normas Internacionales de Contabilidad que para el caso materia de análisis es la Interpretación CINIIF 12 Acuerdos de Concesión de Servicios, que ya determinó claramente como se debe contabilizar la inversión producto de una concesión.

Para concluir con lo señalado por Nalvarte Salvatierra, coincidimos en que la modificación de este artículo debe depender de las características de la concesión y de los criterios plasmados en la Interpretación CINIIF 12 Acuerdos de Concesión de Servicios. Acorde con lo manifestado por el autor y con lo señalado en capítulos anteriores, lo que finalmente determinará el destino de las inversiones para la aplicación del artículo $22^{\circ}$, no sólo es la remisión a la norma contable aplicable, sino principalmente, el análisis de las condiciones establecidas en las cláusulas del contrato de concesión, puesto en base a ellas se sabrá con precisión ante qué tipo de concesión nos encontramos. Si estamos frente a una concesión como la bifurcada o mixta, en la cual el Estado garantiza ingresos al concesionario, contablemente se tratará como activo financiero y su 
destino tributario estará limitado, no pudiendo aplicar el artículo $22^{\circ}$ de la Ley de Concesiones.

En ese razonamiento, resulta importante que, ante una eventual modificación de la norma especial, para tal fin deba tomarse en cuenta indudablemente lo establecido en la Interpretación CINIIF 12, porque así el legislador tendrá un panorama más claro de lo que sucede con una concesión a nivel contable, y así evitará que la finalidad de la norma tributaria se vea afectada.

Prosiguiendo con el análisis de la propuesta de solución mediante una modificación normativa, la reclasificación propuesta del activo financiero a un activo intangible con fines meramente tributarios está basado en el concepto de amortización jurídica como beneficio fiscal. Al respecto, el autor Fernández Pirla señala que "las amortizaciones tienen su natural localización, como ha quedado visto, en el ámbito de los costes, pero tienen una profunda significación financiera en la economía de la empresa”. (como se citó en García Novoa, 1994, p.56).

\section{Agrega Colmenar Valdés que:}

De todo lo visto hasta ahora podemos afirmar que, a través de las amortizaciones, sobre todo en sistemas como el nuestro donde las mismas se practican sobre el coste histórico de los activos, se pretende un efecto financiero esencial: generar los recursos suficientes para recuperar el coste de adquisición de los bienes de inversión. (como se citó en García Novoa, 1994, p.56).

Adicionalmente García Novoa (1994) señala respecto de las amortizaciones que:

Al practicarse la amortización sobre el coste de adquisición nos encontramos ante una pura y simple distribución de este coste en varios ejercicios, por lo que su finalidad financiera se limitará a generar los recursos suficientes para recuperar el valor inicial de los bienes de inversión.

Esta función de la amortización está directamente vinculada a su expresión como partida deducible y ha de regirse por los mismos principios jurídicos. (p.56) 
Como quiera que el desembolso que efectúa el concesionario representa una inversión financiera de gran magnitud, tendrá una importante influencia en el patrimonio de la entidad concesionaria. Concordamos con lo manifestado por 'los autores, en relación al efecto financiero que se persigue con las amortizaciones, el cual es que una entidad pueda recuperar el costo de adquisición de los bienes de inversión. Este efecto, es el que el artículo $22^{\circ}$ pretende otorgarle al concesionario, un mecanismo de recuperación de la inversión a una tasa especial, sin embargo, esto no es posible cuando se tiene un activo financiero.

Añadimos a este razonamiento, que en tanto la propiedad del bien permanezca en el Estado, una concesión en la que se otorga un derecho de uso califica como un activo intangible, al surgir únicamente un derecho de explotación o uso de duración limitada, por lo tanto, el bien materia de concesión calificará como tal y corresponde que sea sujeto de amortización para recuperar su valor en el tiempo.

García Novoa (1994) centra sus ideas finales de las concesiones, en que:

La conclusión, por tanto, es ineluctable; con todas las peculiaridades que puedan atribuirse a un bien inmaterial en la dinámica productiva de la empresa, las concesiones han de ser objeto de amortización, puesto que nos hallamos ante un desembolso que supone una inmovilización de recursos que jurídicamente es objeto de depreciación. (p. 105)

En ese orden de ideas, para aplicar el beneficio fiscal establecido en el artículo $22^{\circ}$ de la Ley de Concesiones, en los modelos concesionarios bifurcados o mixtos, resulta adecuado realizar una reclasificación del activo financiero reconocido contablemente, al activo intangible con fines puramente tributarios. En mérito a que el concesionario adquiere un derecho de uso de duración limitada que es susceptible de amortización, a pesar de que contablemente se reconoce la inversión como un activo intangible y un activo financiero, el concesionario podrá recuperar tributariamente la inversión involucrada en las concesiones, si la totalidad es tratada como un activo intangible. Así se dejará en claro en el artículo $22^{\circ}$ que, para efectos fiscales, las concesiones deberían calificar tributariamente como activo fijo o activo intangible susceptibles de depreciación y amortización. 


\subsubsection{Gasto Deducible}

Si bien nuestra posición favorece en mayor medida a la propuesta desarrollada en el apartado anterior referido a la modificación normativa del artículo $22^{\circ}$, proponemos una alternativa adicional, que también podrá contribuir a mitigar el impacto tributario que genera el reconocimiento de un activo financiero en las concesiones bifurcadas o mixtas. Esta nueva proposición sostiene que normativamente se establezca otra forma de recuperación de la inversión para los activos financieros de una concesión bifurcada o mixta, mediante el uso de un gasto deducible especial que será de aplicación únicamente cuando se esté frente a un activo financiero por consecuencia de la clasificación establecida por las normas contables.

Si bien es cierto, resulta una alternativa compleja, no en el sentido de que sea factible normar un mecanismo como este para los activos financieros de las concesiones, sino que su análisis y elaboración resultan laboriosos. Es una alternativa que puede contrarrestar la distorsión fiscal generada respecto del activo financiero, por la inaplicación del artículo $22^{\circ}$ del Decreto Supremo $N^{\circ}$ 059-96-PCM en las concesiones bifurcadas o mixtas, y consecuentemente, contribuirá a que el concesionario no vea afectada su rentabilidad de manera significativa.

Dicho de otro modo, se propone establecer normativamente un mecanismo de recuperación de la inversión distinto a la depreciación y amortización, para aquellos bienes materia de concesión que no califiquen como activo fijo o activo intangible que contempla el artículo $22^{\circ}$ de la Ley de Concesiones. Para este efecto, se propone la implementación de un gasto deducible especial bajo ciertas condiciones sustanciales, con el fin de que el concesionario goce a través de este de un beneficio fiscal que contribuirá a que el operario recupere parte de su inversión. Cabe resaltar que, esta recuperación tendrá la figura de un gasto deducible para fines fiscales exclusivamente, con limitaciones o parámetros de medición porcentual, temporal, entre otros.

Esta propuesta se basa principalmente en la premisa de que, al término del contrato de concesión, el inversionista debe retornar el bien materia de concesión al Estado, por ello, el mecanismo de recuperación de la inversión que se aplica actualmente es mediante la depreciación y amortización regulada en el artículo $22^{\circ}$. Dado que, este procedimiento de devolución del bien materia de concesión representa para el concesionario una desvinculación de este activo, que tiene un valor económico muy 
importante y ostentoso, se debería introducir en la normativa tributaria un gasto deducible, aplicable a la parte que no gozará de los alcances del artículo $22^{\circ}$, como el activo financiero.

Por consiguiente, creemos que este hipotético gasto deducible deberá tener como condición principal, la existencia contable de un activo financiero bajo la Interpretación CINIIF 12 Acuerdos de Concesión de Servicios, entonces será aplicable siempre y cuando un contrato de concesión celebrado bajo el enfoque bifurcado o mixto diera lugar a la existencia de un activo financiero y estuviera registrado en la contabilidad del concesionario.

Adicionalmente, el mencionado gasto deducible deberá fluctuar cuando menos bajo parámetros numéricos o porcentuales así, por ejemplo, puede deducirse únicamente un determinado porcentaje del valor contabilizado como activo financiero. Otro ejemplo de parámetros de medición puede darse, al considerar que si el valor del bien calificado como activo financiero en la contabilidad es mayor a cierta cantidad de Unidades Impositivas Tributarias (UITs), será deducible un porcentaje de dicho valor. En efecto, en estos casos hipotéticos también será muy importante determinar qué tipo de valor se tomará en cuenta, pudiendo ser el valor razonable, valor histórico, entre otros.

Al respecto, Cañibano y Gisbert (2010) señalan que:

El tratamiento contable del activo financiero queda sujeto al contenido de las normas internacionales relativas a los instrumentos financieros (NIC 32, 39, NIIF 7 y NIIF 9). Así una vez reconocido inicialmente, el activo financiero deberá quedar valorado al cierre de cada ejercicio por su coste amortizado, calculado como su valor razonable inicialmente reconocido, más los intereses devengados en base al tipo de interés efectivo de la operación, menos los pagos realizados por el organismo concedente. (p. $155)$.

Asimismo, otro aspecto a tener en cuenta para este tipo de gasto deducible es la temporalidad, definir si este proceso se realizará durante toda la etapa que tenga vigencia la concesión, o si únicamente se aplicará durante los primeros años, con un tope máximo de periodos, o acorde al periodo de tiempo que se determinó el pago del IMAG en el 
contrato de concesión. Hay que recordar que estos requisitos y parámetros obedecen a políticas fiscales macroeconómicas.

En ese orden de ideas, como podemos apreciar, introducir una nueva forma de deducción de un gasto, resulta una tarea compleja, porque debe estar respaldado de un análisis económico muy detallado y laborioso, que es de suma importancia para llevar a cabo su introducción en las normas tributarias. Pese a la complejidad involucrada en esta propuesta, la misma no resultará imposible de elaborar, puesto que este mecanismo permitirá al concesionario recuperar el costo del activo, el cual tiene una participación importante en el patrimonio de la entidad concesionaria.

Como vimos, el bien materia de concesión es el activo principal de la entidad concesionaria temporalmente, y por ende su explotación servirá para la generación de ganancias que permitan recuperar el valor de este activo en el tiempo. Por lo tanto, al concluir la concesión, este bien que tuvo una repercusión trascendental en el bloque patrimonial de la entidad concesionaria retornará al Estado sin estar sujeto a impuesto alguno, este retorno tendrá un efecto económico significativo en la entidad concesionaria.

Consecuentemente, el derecho de uso del concesionario caduca y será el Estado el nuevo responsable de su uso y explotación. Cuando un bien materia de concesión retorna al Estado, este normalmente sigue en funcionamiento para los usuarios beneficiarios finales, por ende, continúa generando ingresos, pero bajo la gestión del que fue concedente. Por lo tanto, el concesionario se ha desprendido de un valor importante, que tendrá repercusiones financieras sustanciales.

Actualmente, este retorno del activo al Estado es recuperado mediante el mecanismo de amortización y depreciación, establecido en el artículo $22^{\circ}$ de la Ley de Concesiones con un tratamiento especial diferenciado en dicha ley. Sin embargo, para no dejar fuera del ámbito de aplicación a otro tipo de activos que surgen como el caso del activo financiero en la concesión mixta o bifurcada, que no tendrá ningún mecanismo especial de recuperación de la inversión por estar fuera del ámbito de aplicación del artículo $22^{\circ}$, se propone la posibilidad de establecer que esta parte sea recuperada mediante una deducibilidad de gastos adicionales, que de alguna forma le darán el soporte necesario al inversionista cuando se desprenda del bien materia de concesión. 


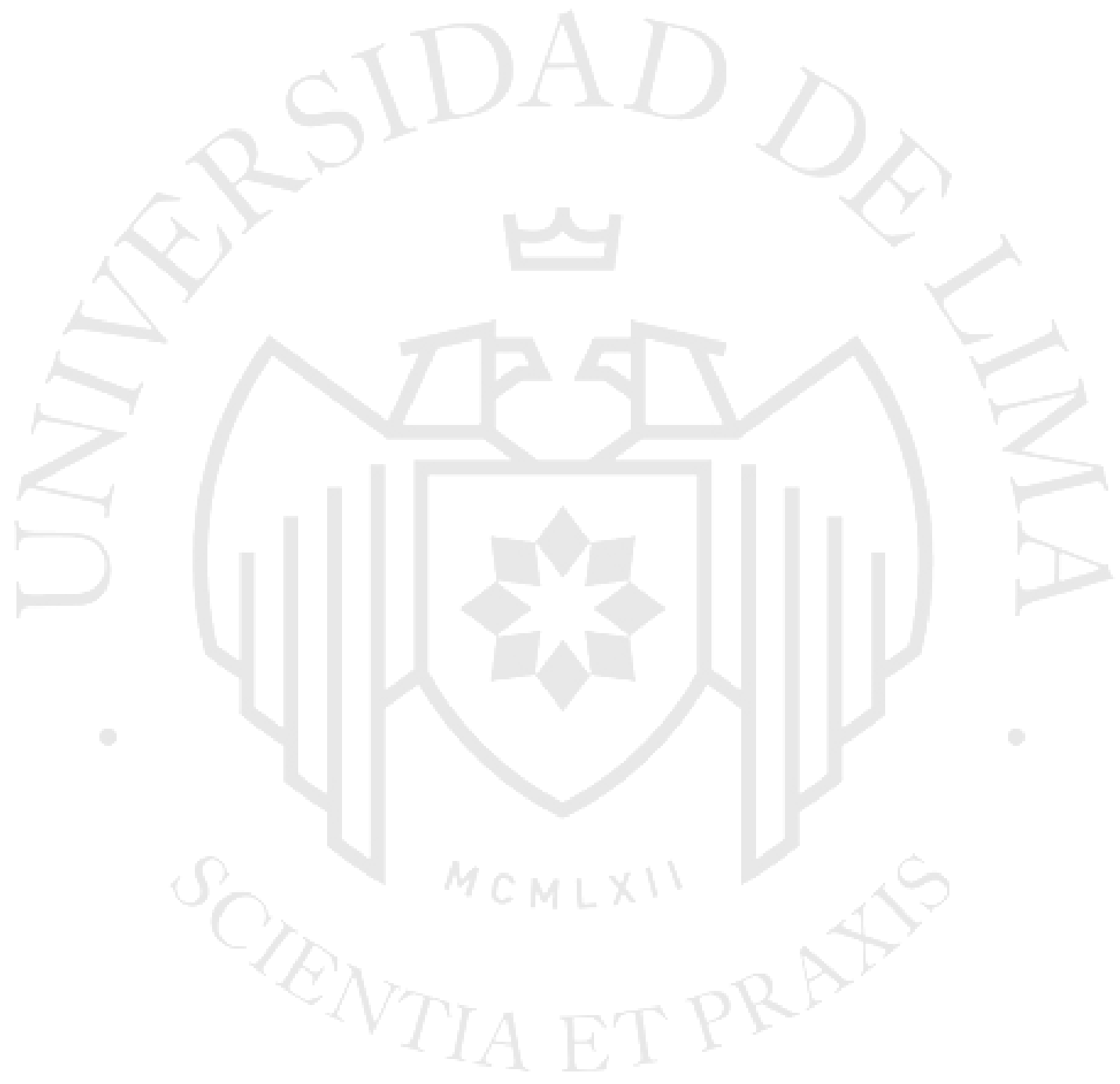




\section{CONCLUSIONES Y RECOMENDACIONES}

- Las concesiones mixtas o bifurcadas son aquellas en las que el riesgo de explotación y/o demanda son compartidos por ambas partes contractuales, concedente y concesionario. El Estado asume contractualmente el citado riesgo por los pagos que se comprometió a otorgarle al concesionario mediante el Ingreso Mínimo Anual Garantizado (IMAG), mientras que la otra parte del riesgo, por los ingresos adicionales generados en la etapa de explotación, es asumido por el concesionario.

- Las concesiones bifurcadas o mixtas no tienen un tratamiento específico en la norma de la materia, el artículo $22^{\circ}$ del Decreto Supremo $N^{\circ}$ 059-96-PCM.

- El artículo $22^{\circ}$ del Decreto Supremo N 059-96-PCM Texto Único Ordenado de las normas con rango de Ley que regulan la entrega en concesión al sector privado de las obras públicas de infraestructura y de servicios públicos, ha delimitado su ámbito de aplicación a los bienes materia de concesión que califiquen únicamente como activos fijos y activos intangibles.

- El artículo $22^{\circ}$ otorga un tratamiento especial aplicable a los bienes materia de concesión, permitiendo que los concesionarios recuperen sus inversiones mediante la depreciación y amortización, los que podrán hacerlo de acuerdo a la vida útil de los bienes, con una tasa máxima anual del $20 \%$ o íntegramente en el periodo que reste para el vencimiento del plazo de la concesión, bajo el método lineal.

- Ante la ausencia normativa, debemos remitirnos a la norma contable, en consecuencia, bajo el enfoque contable de la Interpretación CINIIF 12 Acuerdos de Concesión de Servicios, las concesiones deben tratarse como activos intangibles o activos financieros, de conformidad con el criterio de contraprestación dada por el concedente al operador.

- El concesionario reconocerá contablemente un activo financiero si recibe efectivo de la concedente y representa un derecho contractual incondicional o, reconocerá un activo intangible si recibe una licencia o derecho para cobrar sumas monetarias a los usuarios del servicio público, estos ingresos dependerán del nivel de uso.

- En las concesiones bifurcadas o mixtas, en los que el concesionario y el concedente son responsables del riesgo de explotación y demanda, se reconoce conjuntamente ambos activos señalados por la norma contable. Un activo financiero por el valor que 
representa el Ingreso Mínimo Anual Garantizado (IMAG) otorgado por el Estado y, un activo intangible por el ingreso adicional que perciba el concesionario de los usuarios finales.

- La concesión bifurcada o mixta no está prevista por la actual redacción del artículo $22^{\circ}$ de la Ley de Concesiones que será aplicable únicamente al valor contabilizado como activo intangible, en consecuencia, no tendrá alcance aquel que contablemente se reconoció como activo financiero. La redacción limitada de esta norma fiscal distorsiona su finalidad, que es la recuperación de la inversión mediante mecanismos como la amortización y depreciación en un periodo distinto al regulado en las leyes generales, por lo que la parte reconocida como activo financiero en las concesiones bifurcadas o mixtas no será posible tal recuperación.

- El controvertido artículo $22^{\circ}$, hace alusión a términos exclusivamente contables, siendo indiscutible que el concesionario deba remitirse obligatoriamente a las normas especiales sobre la materia, como la Interpretación CINIIF 12 Acuerdos de Concesión de Servicios, norma que brinda las pautas necesarias para la contabilización de modelos concesionarios como el bifurcado o mixto.

- Al no ser de aplicación el artículo $22^{\circ}$ de la Ley de Concesiones a los activos financieros de una concesión bifurcada o mixta, estos activos estarán sujetos a lo dispuesto por las normas generales tributarias, como la Ley del Impuesto a la Renta y su correspondiente Reglamento.

- Este tratamiento no genera seguridad jurídica en materia tributaria, puesto que tampoco existen pronunciamientos por parte de la Administración Tributaria ni jurisprudencia emitida por el Tribunal Fiscal, sobre la materia, por lo que, el tratamiento fiscal actualmente aplicado está sujeto a futuras contingencias fiscales.

- Consideramos que, el artículo $22^{\circ}$ debería señalar adicionalmente que, para efectos del mismo, el bien materia de concesión reconocido como un activo distinto al activo fijo o activo intangible, será considerado como un activo intangible susceptible de amortización, en la medida que el concesionario haya recibido un derecho de uso durante un tiempo limitado y el Estado no transfiera su derecho de propiedad. Mediante esta salvedad de reclasificación, el activo financiero retornará al ámbito de aplicación del artículo $22^{\circ}$.

- Otra alternativa de solución es, la creación de un gasto deducible únicamente para efectos fiscales y que debe utilizarse siempre y cuando el bien materia de concesión 
califique como activo financiero. En efecto, con este mecanismo de recuperación de la inversión para el concesionario, se pretende resarcir el costo que representa este bien para el inversionista, quien, al finalizar el contrato de concesión, revertirá al Estado el bien materia de concesión.

- En definitiva, es necesaria la modificación del artículo $22^{\circ}$ de la Ley de Concesiones, que permita incluir en su ámbito de aplicación a los activos financieros que son el resultado del tratamiento contable de las concesiones bifurcadas o mixtas bajo la Interpretación CINIIF 12 Acuerdos de Concesión de Servicios. Así se podrá resguardar la finalidad que tiene este artículo. 


\section{REFERENCIAS}

Altamirano, A., Alva, M., Alvarado, E., Araoz, L., Asorey, R., Bardales, P., ... Zuzunaga del Pino, F. (2010). Libro homenaje a Luis Hernández Berenguel (1. a ed.). Lima: Instituto Peruano de Derecho Tributario.

Baca, V., Ortega, E. (2013). Los esquemas contractuales de colaboración público-privada y su recepción por el derecho peruano. Revista de Derecho Administrativo, 13, 33-49.

Barrantes Cáceres, R. (2009). Los fundamentos económicos de las concesiones de infraestructura y servicios públicos. Círculo de Derecho Administrativo, 7, 329337.

Barrantes Cáceres, R. (2012). Desarrollo de la infraestructura de aeropuertos en el Perú. Círculo de Derecho Administrativo. 12, 209-220.

Calafell Irabién, J.E. (1996). Teoría general de la concesión. Jurídica anuario de derecho de la universidad iberoamericana. 26, 216-228.

Cañibano, L., Gisbert, A. (2010). Implicaciones contables de la adopción de IFRIC 12 sobre concesiones de servicios públicos. Revista Española de Financiación y Contabilidad, 39(145), 149-168.

Chang Ching, L. (1999). 18 ${ }^{a}$ B sesión vespertina del Congreso General de la República del Perú llevado a cabo en Lima, Perú. Recuperado del sitio de internet: http://www2.congreso.gob.pe/Sicr/DiarioDebates/Publicad.nsf/SesionesPleno/0 5256D6E0073DFE9052567AF00573B8D/\$FILE/SLO-1998-18B.pdf

CINIIF 12 Acuerdos de concesión de servicios guía práctica de bolsillo. (2011). Recuperado del sitio de internet de Deloitte's IAS Plus: https://www.iasplus.com/en/binary/espanol/1104ifric12guidees.pdf

Constitución Política del Perú (1993). Congreso General de la República, Lima, Perú. Recuperado del sitio de internet del Congreso de la República: http://www.congreso.gob.pe/Docs/files/constitucion/constitucion2019/index.htm $\underline{1}$

Contrato de Concesión de La Autopista del Sol Tramo Trujillo-Sullana (2009). Recuperado https://www.proyectosapp.pe/RepositorioAPS/0/0/JER/AUTOPISTA_DEL_SO L_DOCS_CONTRATO/Version\%20final\%20de\%20contrato.pdf

Cornejo Díaz, R. (2006). Inversión privada en obras públicas de infraestructura y de servicios públicos: una mirada desde el sector público. Thémis Revista de Derecho, 52, 211-229. 
Danós Ordóñez, J. (2006). El régimen de los contratos estatales en el Perú. Revista de Derecho Administrativo, 2, 09-44.

Decreto Legislativo $N^{\circ} 1224$ del Marco de Promoción de la Inversión Privada mediante Asociaciones Público Privadas y Proyectos en Activos (2015). Recuperado del sitio de internet del Ministerio de Economía y Finanzas: https://www.mef.gob.pe/contenidos/inv_privada/normas/app/DL1224_2015EF.p df

Decreto Supremo N ${ }^{\circ}$ 059-96-PCM Texto Único Ordenado de las normas con rango de Ley que regulan la entrega en concesión al sector privado de las obras públicas de infraestructura y de servicios públicos (1996). Recuperado del sitio de internet del Ministerio de Economía y Finanzas: https://www.mef.gob.pe/es/normatividadsp-29923/por-temas/7033-decreto-supremo-n-059-96-pcm/file

Decreto Supremo N 060-96-PCM Reglamento del Texto Único Ordenado de las normas con rango de ley que regulan entrega en concesión al Sector Privado de las obras públicas de infraestructura y de servicios públicos (1996). Recuperado del sitio de internet del Ministerio de Economía y Finanzas: https://www.mef.gob.pe/es/normatividad-sp-29923/por-temas/7035-decretosupremo-n-060-96-pcm/file

Decreto Supremo $N^{\circ}$ 132-97-EF Reglamento de los Beneficios Tributarios para la inversión privada en obras públicas de infraestructura y de servicios públicos. (1997). Recuperado del sitio de internet del Congreso General de la República: http://www2.congreso.gob.pe/sicr/cendocbib/con4_uibd.nsf/568C672A5F56266 905257C5B0059EB20/\$FILE/05-D_S_132-97-EF.pdf

Decreto Supremo N 410-2015-EF Reglamento del Decreto Legislativo No 1224, Decreto Legislativo del Marco de Promoción de la Inversión Privada mediante Asociaciones Público Privadas y Proyectos en Activos. (2015). Recuperado del sitio de internet del Ministerio de Economía y Finanzas: https://www.mef.gob.pe/contenidos/inv_privada/normas/DS410_2015EF.pdf

Escobal Mc Evoy, E. (2017). Las APP en Perú: un caso de éxito mundial peligrosamente vulnerado en el país. Administración Pública \& Control. (42), 10-13.

García Novoa, C. (1994). Las amortizaciones en el impuesto sobre sociedades tratamiento jurídico-tributario. Madrid, España: Marcial Pons.

Gómez de La Torre Barrera, A. (2001). Concesión de obras públicas: ¿promoviendo la inversión privada en el Perú?. Ius et veritas, 22, 72-87.

Informe N. ${ }^{\circ}$ 038-2017-SUNAT/5D0000 (2017). Recuperado del sitio de internet de la Superintendencia Nacional de Aduanas y de Administración Tributaria: http://www.sunat.gob.pe/legislacion/oficios/2017/informe-oficios/i038-2017.pdf

Interpretación CINIIF 12 Acuerdos de Concesión de Servicios. Recuperado de: https://www.mef.gob.pe/contenidos/conta_publ/con_nor_co/vigentes/ciniif/Red BV2018_IFRIC12_GVT.pdf 
Ley de la Actividad Empresarial del Estado Ley $\mathrm{N}^{\circ} 24948$ (1988). Recuperado del sitio de internet: https://www.grupoconsultorefe.com/assets/files/recursos/files/Per\%C3\%BA\%20 -\%20Ley\%20N\%C2\%BA\%2024948_4287.pdf

Nalvarte Salvatierra, P. (2011). Registro de las inversiones realizadas por las empresas concesionarias de infraestructura y de servicios públicos. Derecho \& Sociedad, $36,86-92$.

Nalvarte Salvatierra, P. (2017). Evolución del marco legal de las concesiones y las asociaciones público-privadas en el Perú. Derecho \& Sociedad, 49, 359-379.

Norma Internacional de Contabilidad 16 Propiedades Planta y Equipo (2005). Recuperado de: https://www.mef.gob.pe/contenidos/conta_publ/con_nor_co/vigentes/nic/RedB V2018_IAS16_GVT.pdf

Norma Internacional de Contabilidad 38 Activos Intangibles (2005). Recuperado de: https://www.mef.gob.pe/contenidos/conta_publ/con_nor_co/vigentes/nic/RedB V2018_IAS38_GVT.pdf

Norma Internacional de Contabilidad 39 Instrumentos financieros: reconocimiento y medición (2005). Recuperado de: https://www.mef.gob.pe/contenidos/conta_publ/con_nor_co/vigentes/nic/NIC_0 $\underline{39 \text { 2014.pdf }}$

Pedreschi Garcés, W. (2009). Notas sobre el régimen actualmente aplicable a las concesiones de obras públicas de infraestructura y de servicios públicos de ámbito municipal. Círculo de Derecho Administrativo, 7, 251-274.

Resolución del Tribunal Fiscal No 010577-8-2010 (2010). Recuperado del sitio de internet del Tribunal Fiscal: http://www.mef.gob.pe/contenidos/tribu_fisc/Tribunal_Fiscal/PDFS/2010/8/201 $\underline{0 \_8 \_10577 . p d f}$

Resolución del Tribunal Fiscal Nº 04995-2-2012 (2012). Recuperado del sitio de internet del Tribunal

Fiscal: http://www.mef.gob.pe/contenidos/tribu_fisc/Tribunal_Fiscal/PDFS/2012/2/201 2_2_04995.pdf

Resolución del Tribunal Fiscal Nº 07523-4-2017 (2017). Recuperado del sitio de internet del Tribunal

Fiscal: http://www.mef.gob.pe/contenidos/tribu_fisc/Tribunal_Fiscal/PDFS/2017/4/201 7_4_07523.pdf

Salvatierra Combina, R. (2009). Los contratos de concesión en el sector eléctrico. Círculo de Derecho Administrativo, 7, 317-328.

Tassara Lafosse, D., Gárate Moreno, D. y Cánepa Olaechea, C. (2009). Garantías que otorga el estado en las concesiones de infraestructura. Ius Et Veritas, 39, 146-161. 
Texto Único Ordenado de la Ley del Impuesto a la Renta aprobado mediante Decreto Supremo $\mathrm{N}^{\circ}$ 179-2004-EF (2004). Recuperado del sitio de internet de la Superintendencia Nacional de Aduanas y de Administración Tributaria: http://www.sunat.gob.pe/legislacion/renta/tuo.html

Tuesta, A., Polo, R. (2014). Apuntes en torno al régimen fiscal de las concesiones de obras públicas de infraestructura y de servicios públicos. Revista de Derecho \& Sociedad, 43, 37-44. 


\section{BIBLIOGRAFÍA}

Bravo Orellana, S. (2012). Esquemas de financiamiento de las Asociaciones Público Privadas en el Perú. Círculo de Derecho Administrativo, 12, 197-208.

Calafell Irabién, J.E. (1996). La teoría del acto administrativo. Jurídica anuario de derecho de la universidad iberoamericana. 24, 121-147.

Interpretación SIC-29 Acuerdos de Concesión de Servicios: Información a Revelar. Recuperado de: https://www.mef.gob.pe/contenidos/conta_publ/con_nor_co/vigentes/sic/29_SIC . .pdf

Magide Herrero, M. (2017). Algunas reflexiones a la luz de la nueva ley de contratos del sector público, en particular sobre los contratos de concesión. Actualidad Jurídica Uría Menendez, 46, 40-55.

Maraví Sumar, M. (2009). Procesos de selección regulados en el Perú para el otorgamiento de concesione. Círculo de Derecho Administrativo, 7, 240-249.

Nalvarte Salvatierra, P. (2017). Conceptos y alcances básicos de las asociaciones públicoprivadas. Derecho \& Sociedad, 49, 321-337.038

Oregioni, M., Botero, C. (2017). Importancia y perspectivas de las Alianzas PúblicoPrivadas en el mundo, Latinoamérica y Colombia. Trilogía Ciencia Tecnología Sociedad, 9(17). 133-159.

Rodríguez, S., Castañeda, M. (2016). Concesiones eléctricas: una propuesta para mejorar su financiamiento. Círculo de Derecho Administrativo, 16, 191-200.

Shimabukuro Tokashiki, N. (2016). Privatización y extinción del régimen concesional en materia de servicios públicos y obras públicas de infraestructura en el marco jurídico de promoción de la inversión privada. Círculo de Derecho Administrativo, 16, 75-105.

Velásquez Jara, A. (2018). El fracaso de las Asociaciones Público Privadas (APP) mediante concesión en proyectos de infraestructura de transporte en Perú. Ensayo Académico. Recuperado de: http://repositorio.urp.edu.pe/bitstream/handle/URP/1483/78.\%20\%20Velasquez \%20Jara\%20Arturo\%2C\%20E1\%20fracaso\%20de\%201as\%20asociaciones $\% 20 \mathrm{p}$ \%C3\%BAblico\%20privadas.pdf?sequence $=1 \&$ isAllowed $=\mathrm{y}$ 